LUISE ZOZULA BLIND CARRENHO

Avaliação dos efeitos da subfração acetato de etila III de Vernonia scorpioides em modelo de melanoma murino in vivo e in vitro 


\section{Avaliação dos efeitos da subfração acetato de etila III de Vernonia scorpioides em modelo de melanoma murino in vivo e in vitro}

Dissertação apresentada ao Programa de Pós-Graduação em Patologia Experimental e Comparada da Faculdade de Medica Veterinária e Zootecnia da Universidade de São Paulo, para a obtenção do título de Mestre em Ciências

Departamento:

Patologia

Área de concentração:

Patologia Experimental e Comparada

Orientador:

Prof $^{\circ}$. Dr. Idércio Luiz Sinhorini 
Autorizo a reprodução parcial ou total desta obra, para fins acadêmicos, desde que citada a fonte.

DADOS INTERNACIONAIS DE CATALOGAÇÃO-NA-PUBLICAÇÃO

(Biblioteca Virginie Buff D'Ápice da Faculdade de Medicina Veterinária e Zootecnia da Universidade de São Paulo)

Carrenho, Luise Zozula Blind

FMVZ

Avaliação dos efeitos da subfração Acetato de Etila III de Vernonia scorpioides em modelo de melanoma murino in vivo e in vitro / Luise Zozula Blind Carrenho. - São Paulo : L. Z. B. Carrenho, 2009.

90 f. : il.

Dissertação (mestrado) - Universidade de São Paulo. Faculdade de Medicina Veterinária e Zootecnia. Departamento de Patologia, 2009.

Programa de Pós-Graduação: Patologia Experimental e Comparada. Área de concentração: Patologia Experimental e Comparada.

Orientador: Prof. Dr. Idércio Luiz Sinhorini.

1. Vernonia scorpioides. 2. Atividade antitumoral. 3. Subfração acetato de etila. 4. B16F10. 5. C57BL/6. Título. 


\begin{tabular}{ccccc} 
& & & ERRATA & \\
Página & Parágrafo & Linha & Onde se lê & Leia-se \\
Resumo & $1^{0}$ & $4^{\mathrm{a}}$ & XX f. & $90 \mathrm{f.}$ \\
Abstract & $1^{0}$ & $4^{\mathrm{a}}$ & XX f. & $90 \mathrm{f.}$ \\
\hline
\end{tabular}




\section{UNIVERSIDADE DE SÃO PAULO}

\section{FACULDADE DE MEDICINA VETERINÁRIA E ZOOTECNIA}

\section{CERTIFICADO}

Certificamos que o Projeto intitulado "Avaliação dos efeitos da fração acetato de Vernonia scorpioides em modelo de melanoma murino", protocolado sob o n¹520/2008, utilizando 100 (cem) camundongos, sob a responsabilidade do Prof. Dr. Idércio Luiz Sinhorini, está de acordo com os princípios éticos de experimentação animal da Comissão de Bioética da Faculdade de Medicina Veterinária e Zootecnia da Universidade de São Paulo e foi aprovado "ad referendum".

(We certify that the Research "Evaluation of effect of fraction acetate from Vernonia scorpioides in model of melanoma murine", protocol number 1520/2008, utilizing 100 (one hundred) mice, under the responsibility Prof. Dr. Idércio Luiz Sinhorini, agree with Ethical Principles in Animal Research adopted by Bioethic Commission of the School of Veterinary Medicine and Zootechny of University of São Paulo and was approved "ad referendum" meeting).

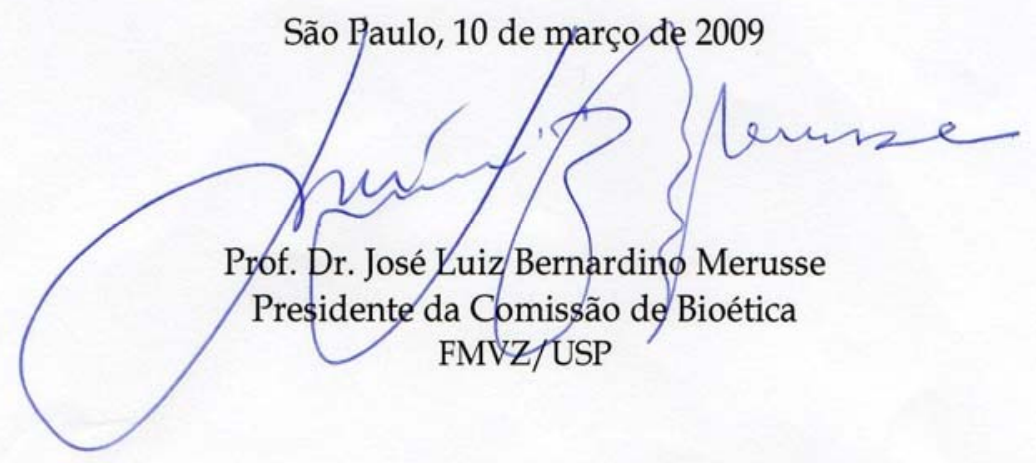




\section{FOLHA DE AVALIAÇÃO}

Nome: CARRENHO, Luise Zozula Blind

Título: Avaliação dos efeitos da subfração acetato de etila III de Vernonia scorpioides em modelo de melanoma murino in vivo e in vitro

Dissertação apresentada ao Programa de Pós-Graduação em Patologia Experimental e Comparada da Faculdade de Medica Veterinária e Zootecnia da Universidade de São Paulo, para a obtenção do título de Mestre em Ciências

Data:_L L L

\section{Banca Examinadora}

Prof. Dr.

Assimatura

Prof. Dr.

Assimatura

Prof. Dr.

Assimatura
Instituição

Avaliação

Instituição

Avaliação

Instituição

Avaliação 
Aquilo que persistimos em fazer torna-se cada vez mais fácil para nós, não que a natureza da coisa em si mude, mas nosso poder de realizá-la aumenta. 
Ao meu grande e maravilhoso paí Frederíco, pelo exemplo que foi em minha vida, sua dedicação a familia, sua simplicidade como pessoa, seus grandes ensinamentos, sempre incentivando seus filhos a estudarem e tornarem-se pessoas melhores, tenho certeza que onde ele esta, olha e sorri com muito orgulhoso.

$\mathcal{A}$ minha amada mãe Díana, uma exemplo de mãe, sempre incentivando, dando injeções de ânimo, apoiando em todas as decisões, sempre ajudando nos momentos que mais necessitei obrigada sem sua ajuda e incentivo não tería chegado até onde chegueí. 


\section{AGRADECIMENTOS}

Ao professor, mestre e amigo Dr. Idércio Luiz Sinhorini, meu orientador, pelo grande estímulo, confiança, apoio e amizade, foi imprescindível para meu aprendizado

A professora Dra. Maria Lucia Zaidan Dagli, minha primeira orientadora, por ter acreditado em meu trabalho, pelo seu grande incentivo e amizade.

A professora, mestre e amiga Dra. Regina Orofino Kreuger, por ter acreditado sempre em meu potencial, estar sempre incentivando, sua garra em lutar pelos seus ideais, seu grande exemplo como mestre dentro da sala de aula por nunca desistir de mim, de todo meu coração muito obrigada.

Ao meu esposo Willian meu eterno amor, pela sua grande compreensão, paciência, seu amor, carinho, atenção e dedicação nos momentos que mais precisei do seu apoio e carinho muito obrigada, te amo.

A minha irmã Leonora, sempre incentivando, ajudando e apoiando, meu cunhado Renato e meus sobrinhos Eduardo e Arthur, pelo apoio, incentivo e ajuda.

Ao meu irmão Leonardo pela sua grande força, incentivo e ajuda para chegar onde cheguei.

A minha Irmã Elise, por ser uma grande companheira sempre incentivando, meu cunhado Wagner pelo apoio.

As minhas irmãs Elena e Eunice pela paciência, à ajuda e grande incentivo.

A minha grande amiga, Márcia Kasume Naganime, um grande exemplo de ajuda ao próximo, por estar sempre disposta a ajudar, sempre arrumando espaço em sua agenda, por ter acompanhado cada experimento, por estar sempre ao meu 
lado dando dicas ajudando, seu incentivo, apoio, compreensão e ensinamentos, muito obrigada mesmo.

A amiga Ivone, pela sua amizade, companheirismo dentro do laboratório, seu grande incentivo e apoio

A Marguiti não só uma técnica, mas, sim uma amiga, pelo seu grande incentivo, ajuda e palavras confortantes em tantos momentos.

A todos meus colegas e amigos do laboratório de Oncologia Experimental pela excelente convivência e sempre auxiliando quando precisei: Marcelo, Krisna, Lucas, Daniel, Katia, Tarso, Bruno, Tereza, Heidge,

A minha amigas Rose, Daisy, Naty pela amizade e grande apoio e incentivo durantes esses anos de estudo,

A professora Dra Maique Weber Biavatti (UFSC) por ter acompanhado todo o processo extrativo, pelos seus grandes ensinamentos, apoio e incentivo.

À Shirley, pelo processamento do material da microscopia e incentivo.

Ao departamento de Patologia (VPT), Laboratório de Oncologia Experimental da Faculdade de Medicina Veterinária e Zootecnia (FMVZ) da Universidade de São Paulo, local onde este trabalho foi desenvolvido.

Aos funcionários do biotério pela dedicação ajuda quando precisei e ótima convivência.

A amiga e secretária Silvia pelas longas conversar de incentivo e ajuda nos momentos que mais necessitei.

As secretárias do departamento pela ajuda e auxilio. 
Às bibliotecárias da FMVZ-USP pela competência e empenho com os quais avaliaram este trabalho

A amiga e secretária Silvia pelas longas conversar de incentivo e ajuda nos momentos que mais necessitei.

As secretárias da pós-graduação pelo auxilio e ajuda

Coordenação de Aperfeiçoamento de Pessoal de Nível Superior, CAPES, Brasil

Muito obrigada a todos que indiretamente e diretamente auxiliaram neste trabalho. 
CARRENHO, L. Z. B. Avaliação dos efeitos da subfração acetato de etila III de Vernonia scorpioides em modelo de melanoma murino in vivo e in vitro. [Evaluation of subfraction ethyl acetate III of Vernonia scorpioides effects in model of murine melanoma in vivo e in vitro] 2009. XX f. Dissertação (Mestrado em Ciências) - Faculdade de Medicina Veterinária e Zootecnia, Universidade de São Paulo, São Paulo, 2009.

Vernonia Scorpioides tem sido utilizada popularmente no Brasil para tratar problemas de pele e úlceras crônicas, como as úlceras de perna decorrentes de diabetes. No presente estudo foi investigado o efeito da subfração acetato de etila III obtida do extrato bruto das folhas de Vernonia scorpioides in vitro, onde células de melanoma murino B16F10 foram submetidas à tratamento com várias concentrações no período de 24, 48, 72 e 96 horas, com o propósito de analisar a citotoxicidade da subfração frente às células. Percebemos uma alta citotoxicidade da subfração matando as células nas concentrações acima de $5 \mu \mathrm{g} / \mathrm{ml}$, as células que receberam o tratamento de $1 \mu \mathrm{g} / \mathrm{ml}$ não sofreram morte celular total. A morte celular foi elucidada com laranja de acridina e brometo de etídio. Um estudo mais detalhado das células foi feito com microscopia eletrônica. No estudo in vivo foi investigada a ação da subfração acetato de etila III na concentração de $5 \mathrm{mg} / \mathrm{Kg}$ em camundongos C57BL6 com o objetivo de verificar a ação da subfração, sete dias de tratamento após dez dias da inoculação, tratamento profilático em dose única no primeiro dia da inoculação e tratamento precoce após 48 horas da inoculação com intervalos de dois dias. Os animais receberam via subcutânea, na região lombar dorsal $1,5 \times 10^{5}$ células de melanoma B16F10. Percebemos que o local em que a subfração acetato de etila III consegue disseminar-se pela massa tumoral ocorre a morte do tumor, extensa área de necrose é observada, quanto mais cedo e precoce o tratamento melhor o comportamento da massa tumoral a subfração acetato de etila III, o único órgão que reage é o baço se apresenta muito reativo proporcionalmente ao tamanho do tumor, os demais órgão não apresentam lesões, a subfração não causou nefrocitotoxicidade e hepatotoxicidade aparente.

Palavras-chave: Vernonia scorpioides. Subfração acetato de etila III. B16F10. 


\section{ABSTRACT}

CARRENHO, L. Z. B. Vernonia scorpioides ethyl acetate III subfraction effect evaluation in model of in vivo and in vitro murine melanoma. [Avaliação dos efeitos da subfração acetato de etila III de Vernonia scorpioides em modelo de melanoma murino in vivo e in vitro.] 2009. XX f. Dissertação (Mestrado em Ciências) - Faculdade de Medicina Veterinária e Zootecnia, Universidade de São Paulo, São Paulo, 2009.

Vernonia scorpioides has been tradionally used in Brazil in order to treat skin disorders and chronic wounds, such as leg ulcers in result to diabetes. The present study investigated the ethyl acetate III subfraction effect obtained from fresh leaves of Vernonia scorpioides in vitro, where B16F10 murine melanoma cells were submitted to treatment with several concentrations during $24,48,72$ and 96 hours, to analyze citotoxicity subfraction before the cells. A high citotoxicity level of subfraction could be noticed killing cells above $5 \mu \mathrm{g} / \mathrm{ml}$ concentration, the cells which received 1 $\mu \mathrm{g} / \mathrm{ml}$ treatment have not suffered total cellular death. This death was elucidated with acridine orange/ethidium bromide staining, a deeper study of the cells was performed with electron microscopy, the action of ethyl acetate III subfraction in the $5 \mathrm{mg} / \mathrm{Kg}$ concentration in C57BL6 mice was investigated in the in vivo study so that it is possible to verify the action of the subfraction seven days of treatment after ten days of inoculation, single dose of prophylactic treatment on the first day of inoculation and precocious treatment after 48 hours of inoculation with 48-hour intervals. The animals received subcutaneously $1,5 \times 10^{5} \mathrm{~B} 16 \mathrm{~F} 10$ murine melanoma cells. Tumor death is noticeable in the area where the ethyl acetate III subfraction could disseminate inside, a comprehensive necrosed area was observed, the sooner and more precocious the treatment the better the tumor will react to the ethyl acetate III subfraction, the only organ that reacts is the spleen which presents itself very reactive to the size of the tumor, the other organs do not display wounds, the subfraction did not cause apparent nefrotoxicity and hepatoxicity.

Keywords: Vernonia scorpioides. ethyl acetate III subfraction . B16F10. 


\section{LISTA DE ABREVIATURAS}

B16F10: melanócitos de melanoma de camundongo.

NF-KB: fator de necrose tumoral KB.

Hela: adenocarcinoma de cérvix humano.

CCD: cromatografia em camada delgada

CGA: campo de grande aumento

HEX: hexano

DCM: diclorometano

AE: acetato de etila

AC: acetona

HE: hematoxilina e eosina

mg: miligrama

$\mu \mathrm{g}$ : micrograma

$\mathrm{ml}$ : mililitro

$\mu \mathrm{m}$ : micrometro

PBS: phosphate buffered solution

rpm: rotação por minuto

RNAm: ácido ribonucléico mensageiro 


\section{SUMÁRIO}

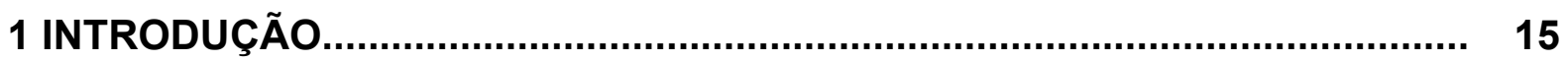

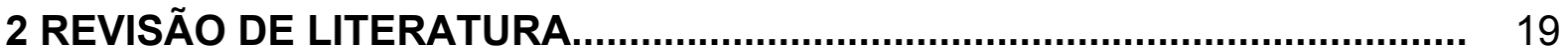

2.1 Melanoma

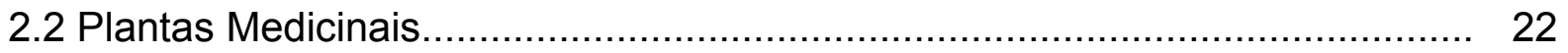

2.3 Gênero Vernonia.................................................................................. 24

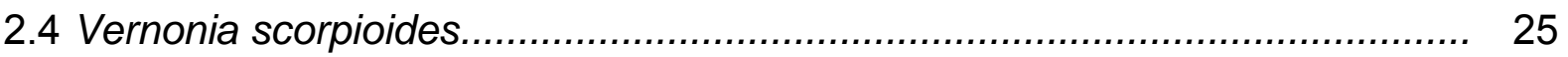

2.5 Lactonas sesquiterpênicas.................................................................... 28

3 OBJETIVOS

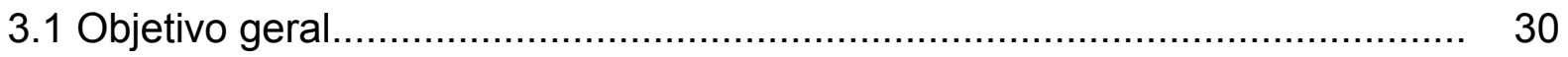

3.2 Objetivos específicos....................................................................... 30

4 MATERIAIS E MÉTODOS....................................................................... 31

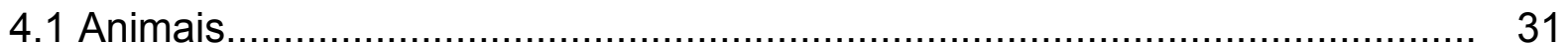

4.2 Obtenção do extrato........................................................................... 31

4.3 Linhagem celular e cultura de células..................................................... 33

4.3.1 Melanoma murino B16F10 ................................................................. 34

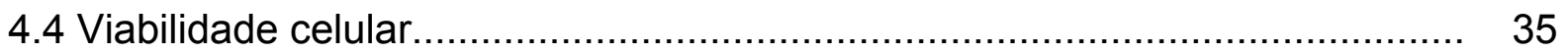

4.5 Ensaio de citotoxicidade ............................................................... 35

4.6 Detecção de morte celular por laranja de acridina e brometo de etídio........... 36

4.7 Verificação de alterações morfológicas....................................................... 37

4.8 Tratamento in vivo durante sete dias....................................................... 38

4.9 Tratamento in vivo em dias alternados.................................................. 39

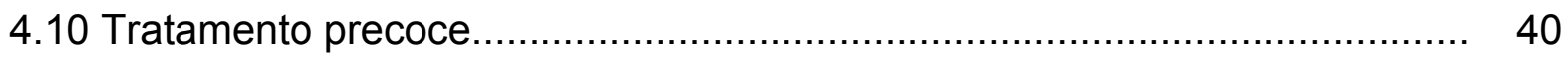

4.11 Cálculo do volume tumoral.............................................................. 40

4.12 Análise estatística........................................................................... 41 
5.1 Rendimento dos extratos.

5.2 Ensaio de citotoxicidade.

5.2.1 Tratamento com a subfração Acetato de Etila III de Vernonia scorpioides por 24 horas

5.2.2 Tratamento com a subfração Acetato de Etila III de Vernonia scorpioides por 48 horas.

5.2.3 Tratamento com a subfração Acetato de Etila III de Vernonia scorpioides por 72 horas.

5.2.4 Tratamento com a subfração Acetato de Etila III de Vernonia scorpioides por 96 horas.

5.2.5 Densidade óptica dos tratamentos com a subfração Acetato de Etila III de Vernonia scorpioides ao longo do tempo.

5.4 Detecção de morte celular - Laranja de acridina e brometo de etídio

5.5 Verificação de alterações morfológicas.

5.6 Avaliação macroscópica dos camundongos.

5.6.1 Tratamento 7 dias.

5.6.2 Tratamento dias alternados e tratamento precoce.

5.7 Avaliação microscópica dos órgãos camundongo C57BL/6.

5.7.1Tratamento sete dias.

5.7.2 Tratamento dias alternados e tratamento precoce.

5.7.3 Volume tumoral. 
Em países desenvolvidos como em subdesenvolvidos, as neoplasias são um problema de saúde pública, representa um distúrbio patológico do crescimento, caracterizado por uma proliferação excessiva e incessante das células. Há uma grande variedade de neoplasias originando-se, basicamente, de todos os tipos de células humanas. O processo de neoplasia não está restrito aos seres humanos, pode se desenvolver na maioria dos vertebrados, alguns insetos e plantas, e a sua existência nestas outras formas de vida têm sido útil no estudo de sua origem e comportamento. Algumas neoplasias são chamadas de "benignas" porque crescem lentamente e permanecem localizadas que geralmente, causam poucos distúrbios aos pacientes acometidos. Outras chamadas malignas ou cancerosas tendem a proliferar rapidamente e a se disseminar pelo corpo de tal forma, que, salvo se tratados com sucesso, eventualmente levam seus hospedeiros à morte. Embora ambos os tipos descrito sejam neoplasias, são as malignas (cânceres) que criam os problemas mais importantes (ANDERSON; JOHN; KISSANE, 1982).

Conforme o comportamento clínico potencial, as neoplasias podem ser invasivas ou não invasivas. Os tumores benignos possuem atipia celular discreta, usualmente eles não são letais tendo uns crescimentos lentos e ordenados, apresentando células que crescem unidas e envoltas por uma pseudocapsula, não possuindo assim caráter infiltrativo nos demais tecidos vizinhos (BRASILEIRO FILHO, 2000).

Em 2005, de um total de 58 milhões de mortes ocorridas no mundo, o câncer foi responsável por 7,6 milhões, o que representou $13 \%$ de todas as mortes. Estimase que, em 2020, o número de casos novos anuais seja da ordem de 15 milhões, sendo que cerca de $60 \%$ desses novos casos ocorrerão em países em desenvolvimento. É também conhecido que pelo menos um terço dos casos novos de câncer que ocorrem anualmente no mundo poderiam ser prevenidos (INCA, 2008).

No Brasil, as estimativas para o ano de 2008 , válidas também para o ano de 2009, apontam que ocorrerão 466.730 casos novos de câncer. Os tipos mais incidentes, à exceção do câncer de pele do tipo não melanoma, serão os cânceres de próstata e de pulmão, no sexo masculino, e os cânceres de mama e de colo do 
útero, no sexo feminino, acompanhando o mesmo perfil da magnitude observada no mundo. Em 2008, são esperados 231.860 casos novos, para o sexo masculino, e 234.870 para o sexo feminino. Estima-se que o câncer de pele do tipo não melanoma (115 mil casos novos) será o mais incidente na população brasileira. Os tumores mais incidentes para o sexo masculino serão devidos ao câncer de pele não melanoma (56 mil casos novos), para o sexo feminino, se destaca os tumores de pele não melanoma (59 mil casos novos) (INCA, 2008).

O melanoma de pele é menos freqüente do que os outros tumores de pele (basocelulares e de células escamosas), no entanto, sua letalidade é mais elevada. A Organização Mundial de Saúde - World Health Organization (WHO) - estima que, anualmente, ocorram cerca de 132 mil casos novos desse câncer no mundo, e, no que se refere à prevalência, seja cerca de 2,5\%. Tem-se observado um expressivo crescimento na incidência desse tumor em populações de cor de pele branca (INCA, 2008).

A prevenção é uma das formas comprovadamente eficazes na prevenção da ocorrência de cânceres. Hoje se sabe que a medicina dispõe de inúmeros métodos no tratamento tumoral, incluindo a quimioterapia, a radioterapia e a cirurgia. A quimioterapia é considerada o mais efetivo método no tratamento do câncer. A intervenção com agentes quimiopreventivos no estágio inicial da carcinogenese é teoricamente mais eficiente que tentar erradicar o desenvolvimento tumoral com drogas quimioterápicas, que atuam tanto em células tumorais quanto em células sadias (AJITH; JANARDHANAN, 2003).

Produtos naturais oriundos de plantas e dietas ricas em nutrientes têm demonstrado serem eficientes na prevenção do câncer. O desenvolvimento de novas e efetivas drogas contra a ação tumoral é de suma necessidade, visto que inúmeros destes tumores são resistentes às drogas existentes hoje no mercado. Estudos a cerca da atividade antitumoral de compostos naturais propagam-se continuamente por todos os institutos de pesquisas mundiais (NEVIN; VIJAYAMMAL, 2003).

A procura de novos fármacos com ação antitumoral e propriedades menos agressivas ao paciente comparada à quimioterapia e radioterapia tem sido de suma importância. Além da diversidade de tumores que ainda não possuem um tratamento satisfatório, os quimioterápicos provocam diminuição de leucócitos, deixando o paciente susceptível a infecções. O possível tratamento que condiciona ao estímulo 
do sistema imunológico auxilia na recuperação do paciente (GALLIN; SNYDERMEN, 1999; HENTY et al., 2001; NEVIN; VIJAYAMMAL, 2003; PAGNO et al., 2006, ROSEMBLAT et al., 2008, BUSKÜHL, 2007).

Com a diversidade de plantas que a flora brasileira oferece as pesquisas com fitoterápicos são motivadas pelos órgãos financiadores de pesquisa nacional. Os extratos brutos ou fracionados têm sido testados in vitro e in vivo por pesquisadores. Muitos destes são utilizados empiricamente pela população, sem conhecimentos de sua eficácia ou toxicidade, pois os resultados cientificamente comprovados são poucos ou inexistentes. Entre estas plantas, está a Vernonia scorpioides, tem sido utilizada popularmente no tratamento de úlceras varicosas no Centro de Convivência de Idosos de Itajaí - SC. Atribui-se aos constituintes desta planta, principalmente as lactonas sesquiterpênicas o seu potencial citotóxico (WARNING et al., 1986; KREUGER et al., 2009, BUSKÜHL, 2007 ).

Vernonia scorpioides conhecida pelo nome de Piracá é utilizada popularmente em diversas afecções de pele, bem como alergias. Estudos realizados indicaram atividade cicatrizante encontrada em Vernonia scorpioides, atividade antifúngica, o potencial de promoção de resposta reparadora, induzido por uma pomada contendo extrato bruto da planta, sendo que esta foi tóxica na fase aguda do processo inflamatório, o mesmo não aconteceu após 21 dias de tratamento, mostrando-se eficiente na resposta cicatricial, quando comparado ao grupo controle (ALMEIDA; PALHANO, 2001; CAMPOS, 2001; DALAZEN; MOLON, 2002).

Vários experimentos têm demonstrado a atividade inflamatória e antitumoral da subfração Diclorometano (DCM) obtida através das folhas e inflorescências de Vernonia scorpioides (PAGNO et al., 2006; BOGONI; DELLAGNELO, 2005).

No gênero Vernonia são encontradas diversas substâncias de classes diferenciadas sendo lactonas sesquiterpênicas possivelmente a responsável pela ação citotóxica (BUSKÜHL, 2007; HUANG; DING; LIU, 2003).

Atualmente sabe-se que as sub-frações de Vernonia scorpioides e outras plantas da família Asteraceae contêm lactonas sesquiterpênicas, muitos são os estudos comprovando a atividade antitumoral destas moléculas, tanto in vitro com in vivo (TWARDOWSKI, 1979; KHALIL et al., 2005; SWEENEY et al., 2005; BUSKÜHL, 2007).

Estudos mostraram a indução de apoptose pela lactona sesquiterpênica, partenolídeo nas células de carcinoma do ducto biliar, onde a diminuição da 
expressão de Bcl-2 e a produção de radicais de oxigênio são os possíveis mecanismos que proporcionam a apoptose por estresse oxidativo. A Vernonia scorpioides é utilizada popularmente como antiinflamatório e cicatrizante, sendo o efeito cicatrizante e a ação antiinflamatória confirmada por estudos realizados anteriormente. A ação antitumoral do extrato diclorometano de Vernonia scorpioides em camundongos foi observada em estudos frente ao tumor de Ehrlich quando tratados por via intraperitoneal. Outra vantagem observada com o tratamento da subfração diclorometano de Vernonia scorpioides foi uma indução do sistema imune verificado pelo aumento de neutrófilos na área tumoral, possibilitando, assim, melhor prognóstico quando comparado ao tratamento com o quimioterápico 5-fluoro-uracil, recentemente foi mostrado à atividade antitumoral in vitro de duas novas lactonas sesquiterpenicas extraídas de Vernonia scorpioides. (ALMEIDA; PALHANO, 2001; PAGNO et al., 2006; BLIND, 2005; DALAZEN et al., 2005; KIM et al., 2005; BUSKUHL, 2007).

Partindo desses resultados este trabalho teve como objetivo avaliar os efeitos da subfração acetato III de Vernonia scorpioides sobre o crescimento de células de melanoma murino B16F10 em cultura, utilizando o método colorimétrico do cristal de violeta, detecção de morte celular pela técnica de laranja de acridina e brometo de etídio, verificação das alterações ultra-estruturais por microscopia eletrônica de transmissão. A avaliação in vivo constituiu no tratamento intratumoral em camundongos $\mathrm{C} 57 \mathrm{BL} / 6$ portadores de melanoma, inoculados com a linhagem celular de melanoma murino B16F10. 


\section{REVISÃO DE LITERATURA}

\subsection{Melanoma}

Hipócrates no século V descreveu pela primeira vez o melanoma. Em 1938 Carswell sugeriu o termo melanoma e relatou as características malignas do tumor.

Embora o melanoma acometa apenas $4 \%$ de todos os tipos de cânceres dermatológicos, é o responsável por $80 \%$ das mortes por câncer de pele, e apenas $14 \%$ dos pacientes com melanoma metastático sobrevivem em média de 5 anos (INCA, 2008; MILLER, 2006).

A Agência Internacional de Pesquisa em Câncer (IARC) estima que pelo menos $80 \%$ dos melanomas sejam causados pela exposição ao sol. Também é o tipo mais freqüente no mundo: até três milhões de casos são diagnosticados a cada ano. A exposição cumulativa e excessiva nos primeiros 10/20 anos de vida aumenta muito o risco de desenvolvimento de câncer de pele: a infância é uma fase particularmente vulnerável aos efeitos nocivos do Sol. O Brasil, país de dimensão continental com área superior a 8,5 milhões de $\mathrm{km}^{2}$, localizado entre os paralelos $5^{\circ}$ $\mathrm{N}$ e $34^{\circ} \mathrm{S}$, tem índices de radiação UVA e UVB que varia muito de uma região a outra. A distribuição fenotípica brasileira apresenta grande heterogeneidade ao longo das latitudes, chegando a $89 \%$ de população de pele clara nas áreas urbanas dos estados de Santa Catarina e Rio Grande do Sul, devido à forte presença da imigração européia (alemães, poloneses, italianos), e caindo a $28 \%$ nas áreas urbanas de Amazonas e Pará (INCA, 2008).

Pele clara associada a uma ocupação que exponha o indivíduo à radiação solar por muitas horas pode aumentar em muito o risco de desenvolvimento do câncer de pele. É o caso dos trabalhadores agrícolas em colônias de origem européia do Sul do Brasil. É importante considerar fatores de risco como a ocupação, quando exige atividades ao ar livre, o local de residência, especialmente em áreas rurais, e o desconhecimento, por parte do indivíduo, de que a exposição excessiva ao Sol pode causar câncer de pele (INCA, 2008).

Os fortes fatores de risco para melanoma são: história familiar de melanoma, nevos benignos múltiplos ou atípicos, e melanoma anterior já diagnosticado, esses 
são os riscos que correspondem à predisposição genética ou um agente estressor que contribuem para os genes do melanoma, quadro 1, assim como também a fase molecular figura 1, onde vários genes importantes estão envolvidos na progressão de melanoma (MILLER et. al. 2006).

\begin{tabular}{|c|c|c|}
\hline Gene & Função & Mudanças em Melanoma \\
\hline $\begin{array}{l}\text { RAS } \\
\text { MAPK }\end{array}$ & $\begin{array}{l}\text { Oncogene } \\
\text { Transdutor de sinal }\end{array}$ & $\begin{array}{l}\text { Ativa mutação } \\
\text { Aumenta atividade }\end{array}$ \\
\hline $\begin{array}{l}\text { INK4A } \\
\text { CDK }\end{array}$ & $\begin{array}{l}\text { Supressor tumoral } \\
\text { Promotor de proliferação } \\
\text { celular }\end{array}$ & $\begin{array}{l}\text { Mutação celular } \\
\text { Mutação celular }\end{array}$ \\
\hline $\mathbf{R b}$ & Supressor tumoral & $\begin{array}{l}\text { Inicia fosforilação para } \\
\text { progressão de G1 para S }\end{array}$ \\
\hline $\begin{array}{l}\text { ARF } \\
\text { p53 }\end{array}$ & $\begin{array}{l}\text { Supressor tumoral } \\
\text { Supressor tumoral, induz } \\
\text { apoptose }\end{array}$ & $\begin{array}{l}\text { Mutação celular } \\
\text { Geralmente expresso em } \\
\text { melanoma }\end{array}$ \\
\hline $\begin{array}{l}\text { PTEN } \\
\text { AKT }\end{array}$ & $\begin{array}{l}\text { Supressor tumoral } \\
\text { Oncogene, quando ativado, } \\
\text { importante para a } \\
\text { sobrevivência celular }\end{array}$ & $\begin{array}{l}\text { Deleção de cromossomo } \\
\text { regional } \\
\text { Amplificado em muitos } \\
\text { melanomas }\end{array}$ \\
\hline $\begin{array}{l}\text { MSH } \\
\text { MITF }\end{array}$ & $\begin{array}{l}\text { Importante molécula } \\
\text { sinalizadas em pigmentação } \\
\text { Fator de transcrição }\end{array}$ & $\begin{array}{l}\text { Aumenta o crescimento } \\
\text { vertical } \\
\text { Amplifica região } \\
\text { cromossomal }\end{array}$ \\
\hline $\begin{array}{l}\text { B - catenina } \\
\text { E - caderina } \\
\text { N - caderina }\end{array}$ & $\begin{array}{l}\text { Proteína de adesão juncional } \\
\text { Molécula de adesão celular } \\
\text { Molécula de adesão celular } \\
\text { Dímero que forma moléculas } \\
\text { de adesão celuar }\end{array}$ & $\begin{array}{l}\text { Estabiliza mutações } \\
\text { Diminui a expressão de } \\
\text { crescimento vertical } \\
\text { Expressão aberrante em } \\
\text { crescimento vertical }\end{array}$ \\
\hline$\alpha V \beta-3$ integrina & & $\begin{array}{l}\text { Expressão aberrante em } \\
\text { crescimento vertical }\end{array}$ \\
\hline
\end{tabular}

Fonte - The New England Journal of Medicine 2006.

Quadro 1 - Genes importantes em melanoma 
Estress ambiental juntamente com uma genética instável de melanoma primário, resulta na seleção e expansão de células malignas. Em geral, o microambiente inflamatório do tumor, contribui para o fenótipo de malignidade do melanoma, por secretar uma variedade de citocinas, quimiocinas e mediadores. Células de melanoma metastático são bem equipadas para resposta a estímulos inflamatórios e usa-os como vantagem para seu crescimento (MELNIKOVA et al., 2009).

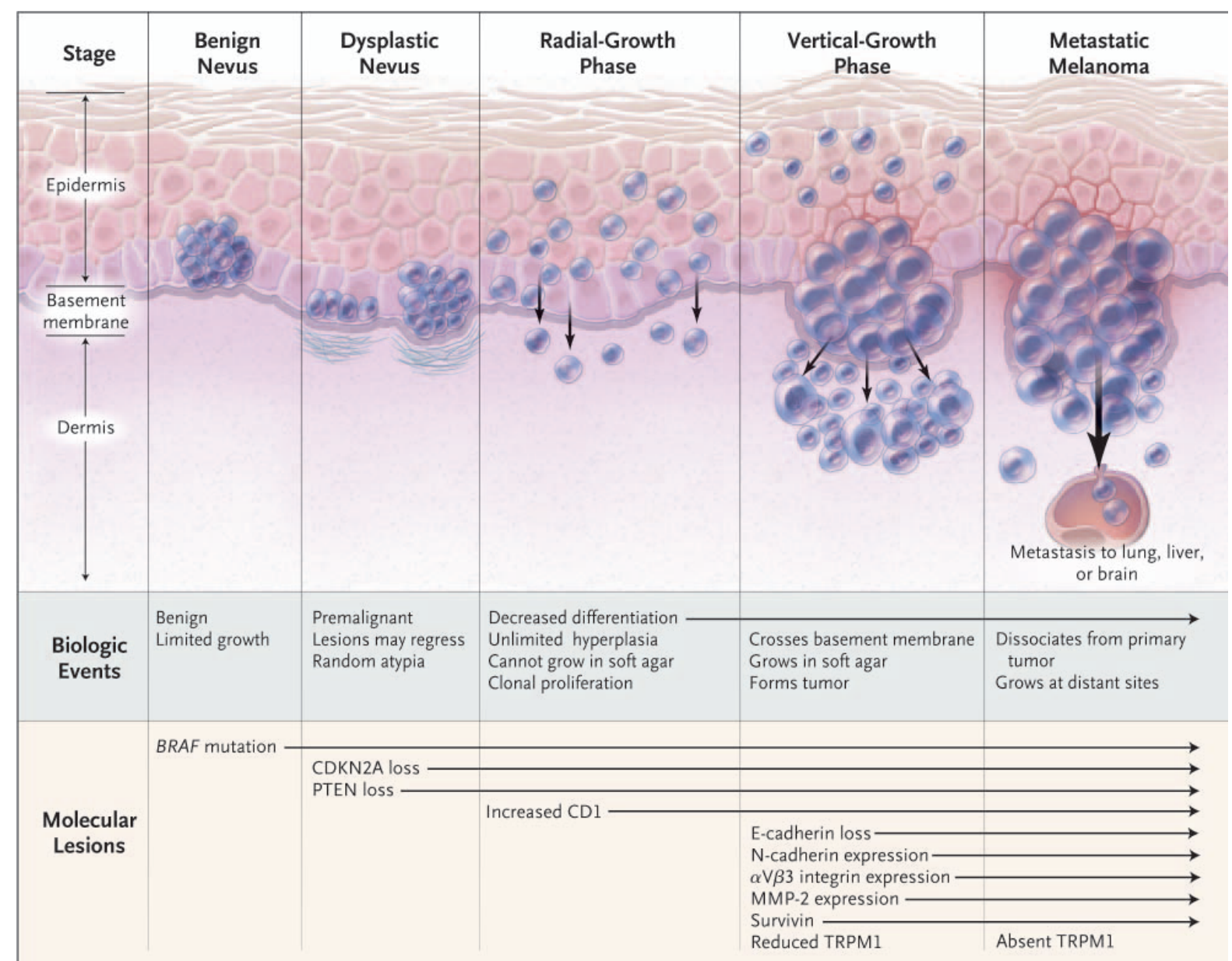

Fonte - The New England Journal of Medecine 2006.

Figura 1 - Eventos biológicos e molecular na progressão do Melanoma.

Melanoma é a forma de câncer de pele mais agressiva e é notória a sua resistência frente a todos os tipos de terapia para câncer já existente, apoptose é considerada o meio mais importante para a morte de células neoplásicas, porém deficiência relacionada a cascata de apoptose pode estar causando um fenótipo de resistência a quimioterapia (HELMBACH et al., 2001). 
Com o objetivo de melhorar o tratamento do melanoma cutâneo algumas abordagens terapêuticas têm sido estudadas, principalmente a eficácia terapêutica onde há um balanço entre benefício e toxicidade em relação à dose-resposta. Imunoterapia e quimioterapia têm sido utilizadas isoladamente, ou em associação com vacinas e anticorpos monoclonais (QUEIROLO et al., 2005).

Dacarbazina quando tratada sozinha não produz efeitos relevantes, porém, quando utilizada em conjunto com interferon alfa produz uma melhora na média de sobrevivência dos pacientes (QUEIROLO et al., 2005). A administração conjunta de talidomida, um agente angiogênico, com temozolomide também demonstrou atividade em melanoma metastático (HWU et al., 2003).

Estudos recentes mostraram que o tratamento em melanoma metastático com combinação de Erlotinib e Bevacizumab além de reduzir significativamente o tumor apresentou uma significante redução do nodo locoregional linfático assim como metástases no pulmão (SCHICHER et al., 2009).

\subsection{Plantas medicinais}

As plantas têm um papel central na prevenção e tratamento das doenças, desde os tempos antigos os humanos já vinham utilizando os constituintes de plantas em tratamento de doenças há um número significativo de drogas modernas potentes usadas na medicina oriundas das plantas. (MANS et al., 2000; TALALAY et al., 2001).

A flora brasileira é muito diversificada e rica, muitas plantas encontradas nos diferentes ecossistemas são usadas na medicina natural, no tratamento de doenças por outro lado, devido ao desconhecimento da possível existência da ação tóxica, bem como de sua indicação adequada, as plantas medicinais são muitas vezes usadas de forma incorreta, não produzindo o efeito desejado (PEREIRA et al., 2004).

Os compostos de origem natural desempenham papéis importantes na medicina moderna. Primeiramente, forneceram alguns medicamentos extremamente úteis. Os produtos naturais também têm sua utilidade como protótipo ou modelos 
para medicamentos sintéticos que tenham atividades fisiológicas semelhantes às dos medicamentos originais (ROBBERS et al., 1997).

A Organização Mundial de Saúde informou que nos Estados Unidos, 25\% das prescrições médicas são baseadas em derivados naturais, $20 \%$ em derivados naturais estruturalmente modificados e que $65 \%$ das prescrições no mundo são baseados em derivados botânicos (SASSI, 2000).

Assim do ponto de vista ecológico, a descoberta de fármacos de origem vegetal é um forte argumento para planejar e aplicas ações de conservação da flora. O valor econômico da preservação de plantas medicinais inclui diversos benefícios sociais, tais como atividades econômicas ligadas ao plantio, processamento e comercialização, melhores condições de assistência de saúde, menor perda de dias de trabalho, além da possibilidade de substituição de fármacos importados, no surgimento de novos modelos para a síntese de fármacos de ferramentas farmacológicas, da conservação de recursos genéticos como fonte de potencial de fármacos para doenças ainda desconhecidas e/ou de novos compostos ativos contra microorganismos resistentes, além dos óbvios benefícios ambientais, pela preservação dos ecossistemas (NUNES, 1996).

Muitas drogas utilizadas para o tratamento de câncer são oriundas de plantas, conforme exemplo de algumas drogas conforme quadro 2.

\begin{tabular}{|l|l|}
\hline \multicolumn{2}{|c|}{ DROGA } \\
\hline Etoposídeo e Tenitoposídeo & Podophyllum peltatum; P. emodi \\
\hline Paclitaxel e Docetaxel & Taxus brevifolia \\
\hline $\begin{array}{l}\text { Irinotecan, Topotecan, } \\
\text { 9 aminocampothecin e } \\
\text { 9-nitrocamptothecin }\end{array}$ & Camptotheca acuminata \\
\hline Vinblastina e vincristina & \\
\hline
\end{tabular}

Fonte dos dados: Mans et al. 2000

Quadro 2 - Exemplos de drogas citotóxicas descobertas a partir de compostos presentes em plantas utilizadas no tratamento de câncer.

Os efeitos medicinais benéficos das plantas são resultantes da combinação dos produtos secundários do metabolismo vegetal presentes nas plantas (BRISKIN, 2000). 


\subsection{Gênero Vernonia}

O gênero Vernonia é pertencente à família Asteraceae (Compositae) compreende 920 gêneros com cerca de 19.000 espécies, sendo a maior família das angiospermas (BRUNETON, 1991). Abrange uma grande diversidade de espécies, com representantes no mundo inteiro. As espécies deste gênero são utilizadas em várias partes do mundo para vários tratamentos de enfermidades. Esta família contém ampla diversidade de constituintes químicos, como alcalóides, cumarinas, saponinas, flavonóides, esteróides, lignóides, triterpenos. Mas são os terpenóides denominados lactonas sesquiterpênicas os compostos característicos da família Asteraceae (PICMAN, 1986; AWE et al., 1998; CARVALHO et al.; 1998; BARBOSAFILHO et al.; 2008).

A variedade de compostos presentes nesse gênero constitui importante tópico para pesquisa na busca da descoberta de novas propriedades medicinais (BOHLMANN et al., 1981; PICMAN, 1986).

$\mathrm{Na}$ Índia foi isolada de partes aéreas de Vernonia arbórea a lactona sesquiterpênica zaluzanina a qual demonstrou $100 \%$ de inibição do crescimento micelar de Rhizoctonia solani e $75 \%$ de inibição contra Curvularia lunata e Botrytis cinerea (KUMARI, 2003).

No Brasil as folhas de Vernonia condensata preparadas por infusão ou decocção, são aplicadas pela população em distúrbios gástricos, diarréia e cefaléia (MONTEIRO et al., 2001) 


\begin{tabular}{|c|c|}
\hline Planta & Atividade \\
\hline $\begin{array}{l}\text { V. colorata } \\
\text { V. kotschyana }\end{array}$ & Erupções cutâneas \\
\hline V. guianensis & $\begin{array}{l}\text { Antihelmintica, afrodisíaca, antídoto para } \\
\text { envenenamento, malária e icterícia. }\end{array}$ \\
\hline V. canescens & Hemorragia e inflamação \\
\hline V. deppeana & Auxilia na dor estomacal \\
\hline V. leiocarpa & Tratamento da asma \\
\hline V. patens & Vermífugo \\
\hline V. cinérea & Antibacteriana \\
\hline V. amygdalina & $\begin{array}{l}\text { Apresentou inibição total do crescimento do } \\
\text { Sclerotium rolfsii e infecções pós } \\
\text { emergentes }\end{array}$ \\
\hline V. condensata & Distúrbios gastrointestinais \\
\hline
\end{tabular}

Fontes dos dados: Picman 1986

Quadro 3 - diferentes espécies de Vernonia e suas variadas atividades biológicas.

\subsection{Vernonia scorpioides}

Conhecida popularmente como Enxuga, Erva-de-São-Simão e Piracá, a espécie Vernonia scorpioides vegeta nas matas e terrenos abertos, é encontrada na região da mata pluvial da encosta atlântica do estado de Santa Catarina - Brasil (CORREA, 1978).

Vernonia scorpioides (Figura 3) é uma planta herbácea de ocorrência comum na Mata Atlântica, Vernonia scorpioides (Lan.) Pers. (FREIRE et al., 2006). Pertence à família Asteraceae, é nativa do Brasil, e considerada como uma importante invasora de pastagens, principalmente nas planícies litorâneas, onde pode formar densos conglomerados (LORENZI, 2000). É um arbusto, com ramos numerosos, lanuginosos; folhas curtas pecioladas, ovaladas, agudas no ápice e atenuadas na base, inteiras nas margens, verdes e glabas na página superior e pardacento- 
hirsutopubescente na página inferior, membranosas; flores de corola purpúrea, reunidas em capítulos numerosos, séssiles, unilaterais, dispostas em panículos alongados escorpióides; fruto aquênio piloso turbinado com papo brancacento (CORREA, 1978; REITZ, 1980).

O extrato de Vernonia scorpioides é popularmente utilizado na cicatrização de úlceras varicosas. Esta erva tropical cresce facilmente em solos pobres e devastados em todo o país, as pessoas nativas recomendam o uso externo de extrato aquoso de Vernonia scorpioides para tratar várias doenças de pele como alergias, parasitas, irritações, prurido entre outras (CABRERA; KLEIN, 1980).

A subfração 2125 de Vernonia scorpioides em modelo ascítico de Sarcoma 180 comparado ao tratamento com quimioterápico 5-fluoro-uracil (5-FU), observou a remissão total do tumor tratado com a subfração, juntamente com uma reação inflamatória aumentando o número de leucócitos no peritôneo dos animais, verificou também que a subfração perdeu sua atividade por via intravenosa (KREUGER et al., 2009).

Diversos estudos têm demonstrado que frações obtidas desta planta apresentam atividades antifúngicas, antimicrobianas, antitumoral e antiinflamatória (PAGNO et al., 2006; BOGONI; DELLAGNELO, 2005). Esta planta já tem sido estudada em diversas atividades biológicas, apresentando efeitos citotóxicos na maioria dos testes realizados. Estudos prévios mostraram que o extrato e suas frações clorofórmio e hexano tem atividade fungicida (FREIRE et al., 1996), a subfração diclorometano e a hexano são bactericidas e fungicidas (CAMPOS, 2001), e a subfração Acetato de Etila inibiu a gliceraldeido-3-fosfato desidrogenase de Trypanossoma cruzi (ALBERTON, 2002), a subfração DCM aumentou o número de leucócitos em diferentes modelos inflamatórios experimentais, sugerindo citotoxicidade pró-inflamatória (BOGONI; DELLAGNELL0, 2005).

A intenção de procurar por mais produtos biologicamente ativos naturais, especialmente aqueles derivados de plantas teve como objetivo estudar os efeitos do extrato de folhas de Vernonia amydalina, as concentrações da fase aquosa apresentaram uma potente inibição da síntese de DNA, sugerindo que a planta Vernonia amydalina incorporada na dieta pode prevenir ou eliminar câncer de mama (IZEVBIGIE, 2003).

Estudos mostraram que a subfração DCM desta planta apresenta atividade tumoricida quando em contato direto com a célula tumoral de Erlich eliminando o 
tumor dos animais tratados por via intraperitoneal, no mesmo local de desenvolvimento do tumor (PAGNO, 2004).

A atividade antitumoral em tumor ascítico de Erlich da subfração DCM II de Vernonia scorpioides, apresentando uma remissão completa das células tumorais, foi mostrada em estudos já realizados (BLIND; MOYA, 2005).

As moléculas que possuem atividade antitumoral extraídas da planta Vernonia scorpioides apresentam atividade citotóxica direta quando em contato direto com as células tumorais, sendo desativadas no organismo ou até mesmo não penetrando na célula alvo. Realizando o tratamento tanto por via oral ou por via endovenosa a atividade antitumoral é ineficaz ou inexistente (PAGNO, 2004; PACHECO; JUNIOR, 2005).

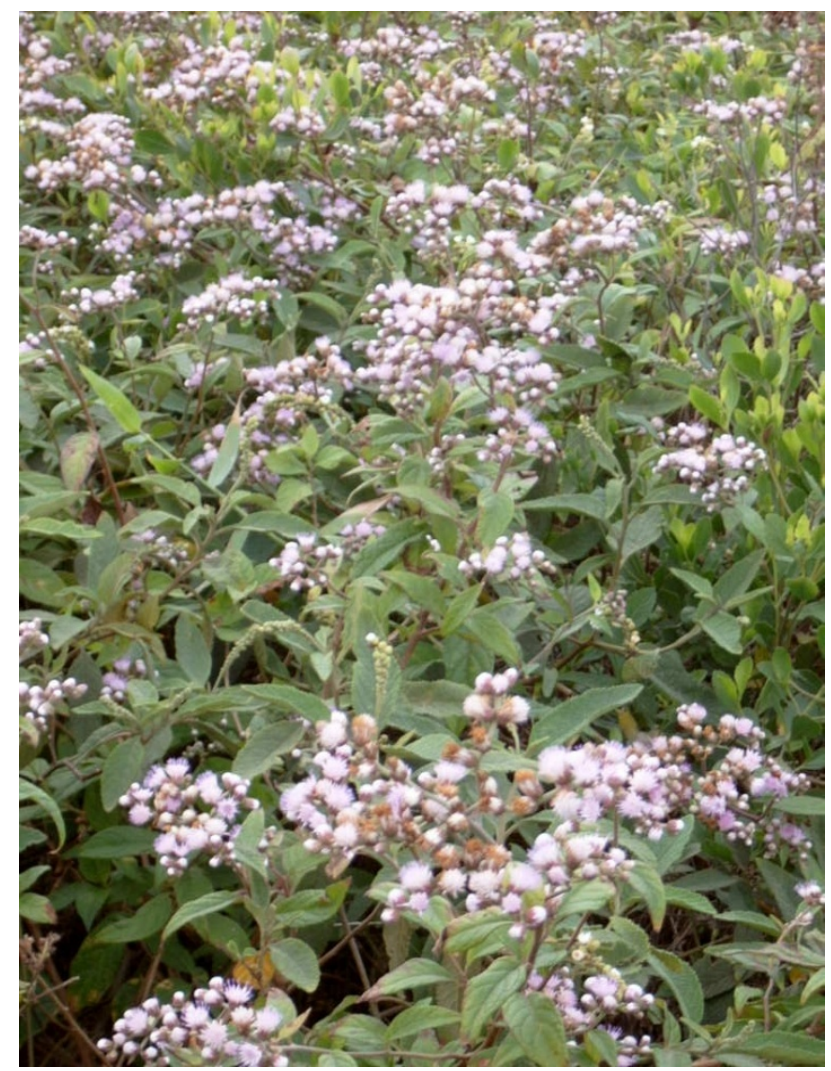

Figura 2 - Florescência da Planta Vernonia scorpioides (Lam) Pers 


\subsection{Lactonas sesquiterpênicas}

Plantas da família Compositae produzem vários compostos sesquiterpenoides, especialmente em seu metabolismo secundário produzem as lactonas sesquiterpênicas que representam constituintes ativos de uma variedade de plantas medicinais usadas na medicina tradicional para o tratamento de doenças inflamatórias. Recentes estudos nos últimos anos têm atraído a atenção da propriedade antitumoral das várias lactonas sesquiterpênicas com um extenso interesse em estudar as características da sua atividade antitumoral, o mecanismo molecular o seu potencial preventivo e terapêutico aplicado as lactonas sesquiterpênicas (BOHLMANN et al., 1978; MUHAMMAD et al., 2003; ZHANG, 2005; CHEN, 2006).

Lactonas sesquiterpênicas representam constituintes ativos de uma variedade de plantas medicinais usadas na medicina tradicional para o tratamento de doenças inflamatórias. Nos últimos anos a propriedade antitumoral das várias lactonas sesquiterpênicas tem atraído um extenso interesse em estudar as características da sua atividade antitumoral, o mecanismo molecular e o seu potencial preventivo e terapêutico aplicado as lactonas sesquiterpênicas (ZHANG, 2005).

Compreendem um grupo de substâncias com uma enorme variedade de efeitos biológicos. Estes compostos são terpenóides que constituem uma grande variedade de substâncias vegetais. Embora lactonas sesquiterpênicas formem compostos terpenóides característicos das Asteraceae, elas são bem conhecidas também de outras famílias de Angiospermas assim como de algumas Gimnospermas. São compostos que tem propriedades citotóxicas, antitumoral, antibacteriana e antifúngica, são extremamente distribuídas entre as espécies vegetais (PICMAN, 1986).

As lactonas sesquiterpênicas são divididas basicamente em quatro sub-grupos: Eudesmanolideos; Germacranolideos; Guaianolideos e o Pseudoguaianolideos (RODRIGUEZ; TOWERS; MITCHELL, 1976; HARBORME; BAXTER, 1993). Os Hirsutinolideos e glaucolideos são germacranolides altamente oxigenados, e foram isolados de várias espécies de Vernonia (HARBORNE; BAXTER, 1993).

As plantas medicinais que possuem lactonas sesquiterpênicas são utilizadas, popularmente, no tratamento de doenças inflamatórias. Ainda, a atividade 
antitumoral destas substâncias vem sendo estudada para a elucidação do mecanismo de ação tanto antitumoral como anti-inflamatório (ZHANG et al., 2005).

Várias lactonas sesquiterpênicas são conhecidas por serem tóxicas em humanos, animais parasitas, insetos e vertebrados. Muitos desses compostos ou plantas contendo estes são as causas de dermatite alérgica de contato em humanos, porém muitos deles são bem usados por sua atividade farmacológica (PICMAN, 1986).

Evans (1991) em seus estudos com as lactonas sesquiterpênicas também demonstrou suas propriedades antitumorais, citotóxicas e antimicrobianas.

Várias atividades biológicas das lactonas sesquiterpênicas como atividades antitumoral em alguns modelos in vivo e in vitro, atividade antibacteriana em cepas de Mycobacterium tuberculosis, M. diphtheriae, Staphylococcus aureus e Bacillus subtilis, atividade anti-fúngica contra Candida albicans, Trichophyton mentagrophytes, Saccharomyces cerevisiae entre outros, atividade anti-protozoária contra Entamoeba histolytica, Trichomonas vaginalis, Plasmodium vivax e Plasmodium falciparum (PICMAN, 1986).

Cinco lactonas isoladas da Calea urticifolia da família Compositae em recentes estudos mostraram atividade antimelanótica em células de melanoma B16F10, duas apresentaram potente ação antimelanótica por modulação da transcrição do RNAm tirosinase, sendo uma lactona induziu apoptose das células (OHGUCHI et al., 2009).

Atualmente já sabemos que as sub-frações de Vernonia scorpioides e todas outras plantas da família Asteraceae contêm lactonas sesquiterpênicas, muitos são os estudos comprovando a atividade antitumoral destas moléculas, tanto in vitro com in vivo (KHALIL et al., 2005; SWEENEY et al., 2005; BUSKUHL, 2007). 


\section{OBJETIVOS}

\subsection{Objetivo geral}

Determinar o efeito da subfração Acetato de etila III de Vernonia scorpioides sobre o crescimento de linhagem de células de melanoma F 10 in vivo e in vidro.

\subsection{Objetivos específico}

- Realizar estudo dos efeitos da subfração Acetato de etila III de Vernonia scorpioides sobre a proliferação e morte celular com varias concentrações e diferentes horas em células de melanoma B16F10 in vitro.

- Verificar a atividade da subfração Acetato de etila III de Vernonia scorpioides em animais inoculados com células de melanoma B16F10 tratados na concentração de $5 \mathrm{mg} / \mathrm{Kg}$, tratamento intra tumoral durante 7 dias.

- Verificar a atividade da subfração Acetato de etila III de Vernonia scorpioides em animais inoculados com células de melanoma B16F10 tratados na concentração de $5 \mathrm{mg} / \mathrm{Kg}$, tratamento intra tumoral, iniciando após 2 dias da inoculação com intervalo de dois dias entre os tratamentos.

- Verificar a atividade da subfração Acetato de etila III de Vernonia scorpioides em animais inoculados com células de melanoma B16F10 tratados na concentração de $5 \mathrm{mg} / \mathrm{kg}$, dose única sendo inoculada após 5 minutos da inoculação das células de melanoma.

- Realizar estudo histopatológico, ultraestrutural e morfométrico da massa tumoral após o tratamento com o extrato de Vernonia scorpioides. 


\section{MATERIAIS E MÉTODOS}

\subsection{Animais}

Foram utilizados 50 camundongos fêmeas C57BL/6 com aproximadamente 60 dias de idade, provenientes do biotério do Departamento de Patologia da Faculdade de Medicina Veterinária e Zootecnia da Universidade de São Paulo (FMVZ-USP). Os animais foram utilizados em conformidade com as normas e procedimentos éticos relativos ao uso de animais de laboratório da FMVZ-USP, protocolo $n^{\circ}$ 1520/2008. Durante todos os experimentos os animais foram alojados, em grupos de cinco animais, em caixas de plástico fosco com tampas metálicas, medindo 19,5 x 29,5 x $13 \mathrm{~cm}$, as quais foram mantidas em salas com temperatura e umidade aproximadamente constantes (temperatura entre $22-25^{\circ} \mathrm{C}$ e umidade relativa de 65 a $70 \%$ ) através de aeração, exaustão e ventilação. A iluminação da sala foi mantida em ciclo de noite/dia de $12 \mathrm{~h}$, sendo a fase clara iniciada às 6:00 horas. Os camundongos foram alimentados com a ração NUVILAB NUVITAL, balanceada para roedores, e água fornecida ad libitum. Todos os camundongos foram mantidos nestas condições por um período de adaptação de no mínimo três dias antes do início de cada experimento, quando estes foram pesados para o controle de peso e para o ajuste da dose da planta.

\subsection{Obtenção do extrato}

Folhas e inflorescências de Vernonia scorpioides foram coletadas na cidade de Navegantes, Santa Catarina, no endereço: Avenida Ivo Silveira, próximo à praia do Molhes, em ambiente de duna fixa e solo arenoso. A espécie foi identificada pela botânica Ana Claudia Araújo. A exsicata do vegetal encontra-se no herbário Barbosa Rodrigues sob especificação, Maique W. Biavatti 11 (15/03/2001).

O processo extrativo foi realizado com monitoramento químico por cromatografia em camada delgada (CCD), com padrão de lactona sesquiterpênica 
obtida por estudos anteriores, de todas as frações obtidas para direcionamento a separação por cromatografia subseqüente conforme figura 3 .

$O$ extrato bruto de $V$. scorpioides foi obtido por maceração de folhas $e$ inflorescências verdes, em etanol bidestilado, por 30 dias. Após, o extrato foi concentrado em rota-evaporador, reduzindo em $95 \%$ o volume alcoólico. Foram utilizados 18 litros de etanol para $5 \mathrm{~kg}$ da planta.

FASE I - Ao extrato bruto preparado acima foi adicionado $1 / 3$ de água do seu volume para então ser submetido a uma partição líquido - líquido através de um funil de separação, com solventes de polaridade crescente sendo: hexano (HEX), diclorometano (DCM), Acetato de Etila (AE), procurando assim obter uma semipurificação dos compostos de acordo com as suas polaridades.

Nesse processo de extração foram utilizados $1000 \mathrm{~mL}$ de cada solvente. As frações obtidas foram reduzidas à secura com auxilio de um secador de cabelos, até eliminação do solvente obtendo-se assim, as respectivas frações: HEX I, DCM I, AE I.

FASE II - a subfração DCM I foi submetida a uma partição em sílica e cromatografia. Assim como na fase anterior, as frações foram reduzidas à secura obtendo-se as seguintes subfrações: HEX II, DCM II, DCM: AE II, AE II, METANOL II.

FASE III - a subfração DCM II foi submetida à cromatografia em coluna flash e reduzida à secura assim como nas outras fases, obtendo-se assim as seguintes frações semi-puras: HEX III, DCM III, ACETATO DE ETILA III. 


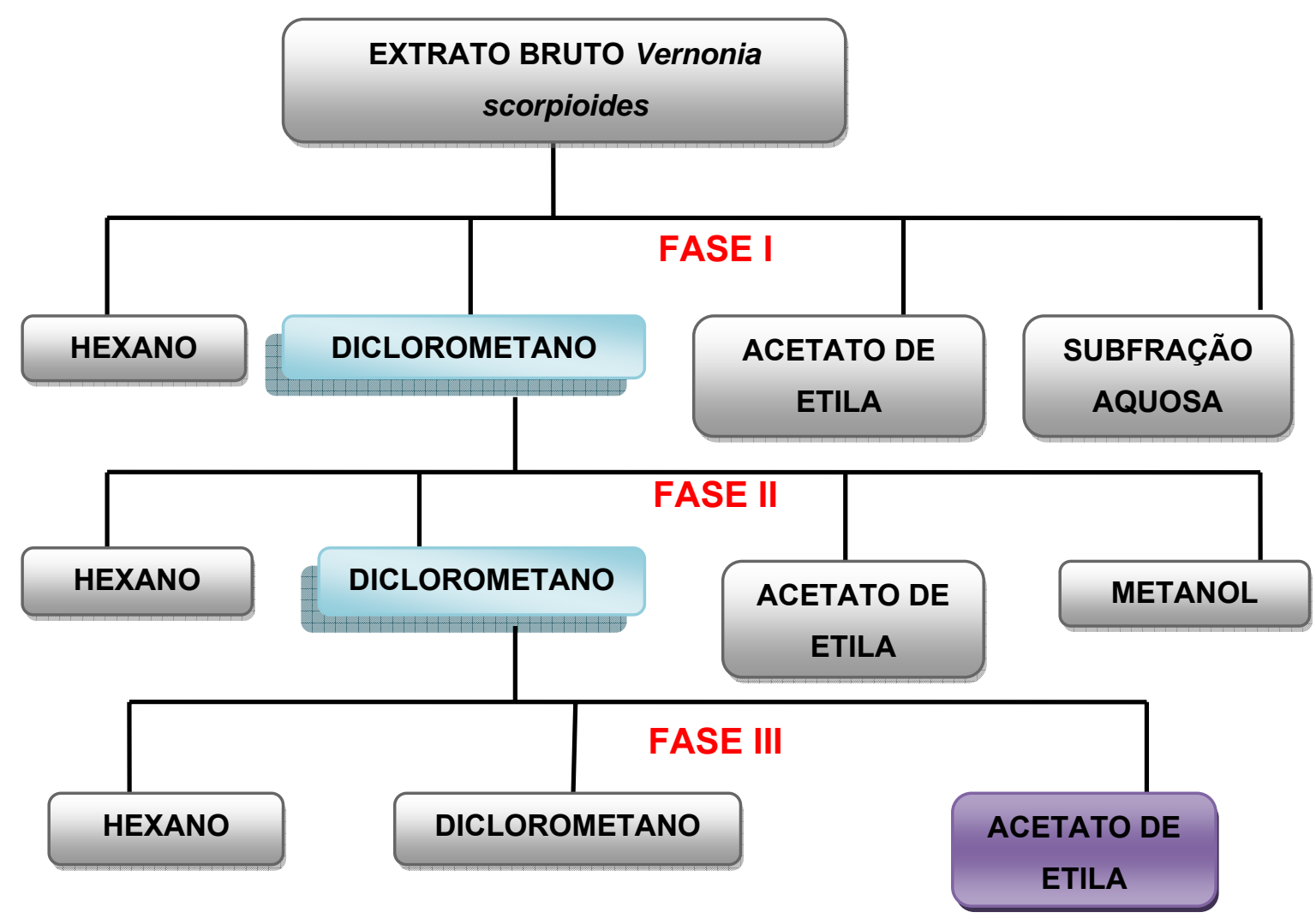

Figura 3 - Fluxograma mostrando delineamento da obtenção da subfração acetato de etila III

Todos solventes utilizados possuem grau de pureza para HPLC (VETEC $\left.{ }_{\circledast}\right)$.

Para o tratamento in vivo e in vitro a subfração acetato de etila III foi diluída em solução salina a $0,9 \%$ com $0,1 \%$ de tween 80 e submetida à lavadora ultra-sônica por 30 minutos para uma melhor dissolução da subfração.

\subsection{Linhagem celular e cultura de células}

Filder foi quem estabeleceu a linhagem B16F10 oriunda do melanoma de ocorrência natural do camundongo C57BL6 que, por meio de seleção progressiva, obteve $\mathrm{o}$ isolamento de variantes com diferentes graus de potencial metastático. Também foi relatado que o número de metástases experimentalmente obtidas é 
proporcional ao numero de células viáveis inoculadas e que muitos êmbolos tumorais falham em formar metástases e morrem (FILDER, 1973).

Inoculadas por via subcutânea, apresentam a capacidade de multiplicação neoplásica sem proporcionar o desenvolvimento de metástases enquanto que, quando inoculadas por via endovenosa, desenvolvem nidação em parênquima pulmonar formando nódulos macroscópicos na superfície dos pulmões (BIONDI, 2006).

\subsubsection{Melanoma murino B16F10}

As células de melanoma da linhagem B16F10 foram cultivadas no Laboratório de Oncologia Experimental do Departamento de Patologia da Faculdade de Medicina Veterinária e Zootecnia/USP.

Após descongelamento rápido em banho-maria a $37^{\circ} \mathrm{C}$, as células foram transferidas do frasco de congelamento para um tudo cônico de centrífuga onde já havia $10 \mathrm{ml}$ de meio RPMl sendo, então submetidas à centrifugação a 1200 RPM. Para replicação celular, as células foram semeadas em garrafas de cultura, em meio RPMI suplementado com $10 \%$ de soro fetal bovino e mantidas em estufa umidificada com $5 \%$ de $\mathrm{CO}_{2}$, a $37^{\circ} \mathrm{C}$. O descolamento das células para posterior replicação das células foram tripsinizadas, processo que neutraliza a adesão das células ao substrato (garrafa), possibilitando que se soltem para novo plaqueamento. $O$ processo constituiu na lavagem da cultura uma vez com PBS, para remoção do meio de cultura, incubação com tripsina-EDTA 0,25\% em PBS, por 5 minutos, apos a incubação, foi adicionado meio RPMI com $10 \%$ de soro fetal bovino para inativação da tripsina, as células foram centrifugadas a 1200 RPM, por 10 minutos ressuspendidas em meio e homogeneizadas vigorosamente para dissolver os aglomerados celulares. Para o plaqueamento, as células após serem ressuspendidas foram contadas na câmara de Newbauer e a viabilidade celular determinada pelo método de exclusão do corante de azul de tripan (0,01\% em PBS). Auxiliando na diferenciação entre células vivas e células mortas, por utilizar a propriedade de este corante penetrar apenas em células vivas. Foi adotada uma concentração de $10^{5}$ células para o cultivo em garrafas. 
Colheu-se uma alíquota de $10 \mu$ para avaliação da viabilidade celular e contagem de células.

\subsection{Viabilidade celular}

A viabilidade das células foi verificada com o corante vital Azul de Tripan. Células vivas apresentam-se não coradas, refringentes à luz, enquanto as células mortas coram-se em azul. A viabilidade dos cultivos celulares foi determinada, então, pela contagem das células em câmara de Newbauer em microscópio óptico. As células viáveis e não viáveis foram contadas em porcentagem de células totais. Considerou-se adequada, a cultura com um total de pelo menos $95 \%$ de células viáveis.

\subsection{Ensaio de citotoxicidade}

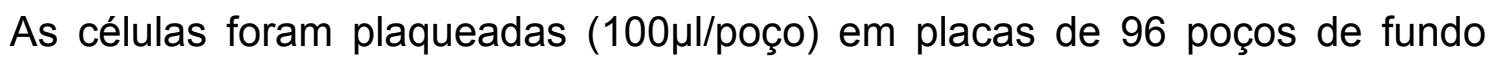
chato estéril (corning) em concentração de $5 \times 10^{4}$ células $/ \mathrm{ml}$ para tratamento de 24 horas, $3 \times 10^{4}$ células $/ \mathrm{ml}$ para tratamento de 48 horas, $2 \times 10^{4}$ células $/ \mathrm{ml}$ para tratamento de 72 e 96 horas. As placas foram pré-incubados por 24 horas em estufa a $37^{\circ} \mathrm{C}\left(5 \%\right.$ de $\mathrm{CO}^{2}$ e $100 \%$ umidade relativa). Após as 24 horas, as células foram

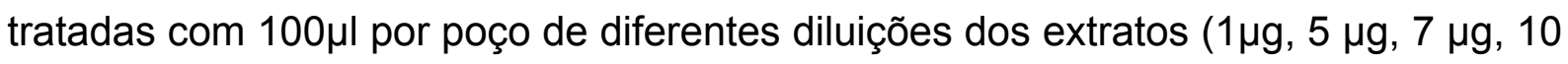
$\mu \mathrm{g}, 25 \mu \mathrm{g}, 50 \mu \mathrm{g}, 70 \mu \mathrm{g}$ e $100 \mu \mathrm{g}$ ), duas vezes a concentração, a fim de se alcançar a concentração final desejada. Dois grupos controles foram adicionados a cada placa sendo um grupo que só recebeu meio RPMI com $10 \%$ de soro fetal bovino e outro grupo controle com o solvente utilizado para a diluição da subfração Acetato de etila III (salina $0,9 \%$ e tween 80 a $0,1 \%$ ). As células foram incubadas por 24, 48, 72 e 96 horas de acordo com o tempo de tratamento. A coloração das células foi feita adicionando-se $20 \mu \mathrm{l} /$ poço de cristal violeta, permanecendo por 10 minutos, logo após sendo lavada. As placas foram deixadas para secar em temperatura ambiente, após o qual foi adicionado $100 \mu l$ poço de metanol para a realização da 
leitura. A leitura foi feita em leitor de ELISA com filtro para comprimento de onda de $540 \mathrm{~nm}$.

Para determinar o efeito do tratamento sobre as células foi utilizado a seguinte formula:

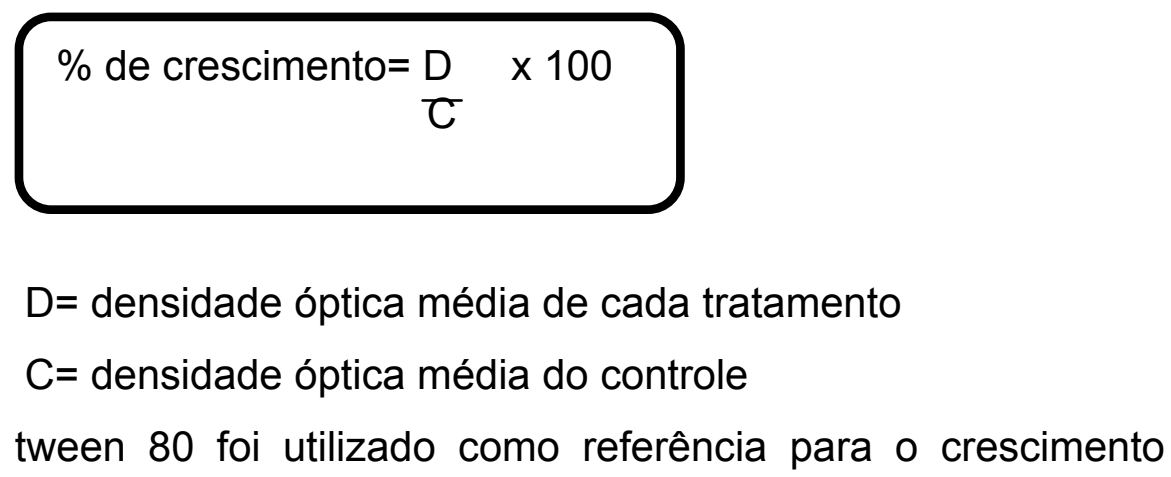
celular

4.6 Detecção de morte celular por laranja de acridina e brometo de etídio

As células de melanoma B16F10 foram plaqueadas $(100 \mu \mathrm{l} / \mathrm{poço})$ em placas de 96 poços de fundo chato estéril (Corning) em concentração de $5 \times 10^{4}$ células $/ \mathrm{ml}$ e pré incubadas por 24 horas em estufa a $37^{\circ} \mathrm{C}\left(5 \%\right.$ de $\mathrm{CO}_{2}$ e $100 \%$ umidade relativa).

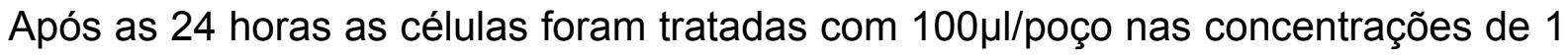
$\mu \mathrm{g}, 5 \mu \mathrm{g}, 25 \mu \mathrm{g}, 50 \mu \mathrm{g}$ de subfração Acetato de etila III, duas vezes concentrados, a fim de se alcançar a concentração final desejada. Um grupo controle recebeu meio RPMI-1640 acrescido de 10\% de soro fetal bovino, e outro grupo controle recebeu $0,1 \%$ de tween 80 em solução salina. As células foram incubadas por mais 1, 6, 12, 24 horas. Após o período de incubação, o sobrenadante dos poços foi retirado e recolocado $25 \mu \mathrm{l}$ do mesmo sobrenadante em cada poço. A verificação de células mortas e vivas após o tratamento com a subfração acetato foi feita adicionando-se 1 $\mu \mathrm{l}$ de solução contendo laranja de acridina $(100 \mu \mathrm{g} / \mathrm{ml})$ (Sigma) e brometo de etídio (100 $\mu \mathrm{lg} / \mathrm{ml})$ (Sigma) na proporção de $1: 1$, para cada $25 \mu \mathrm{l}$ de meio contendo as células (SPECTOR, 1998).

A visualização foi feita em microscópio de fluorescência Nikon Eclipse E800 com filtro para FITC/Texas Red, logo após a adição da solução. As imagens foram 
obtidas com o auxílio do software Image-Pro Plus versão 4.5 (Media CyberneticsEUA).

\subsection{Verificação de alterações morfólogicas}

As células foram plaqueadas ( $300 \mu \mathrm{l} /$ poço) em placas de 24 de fundo chato estéril (Corning) em concentração de $5 \times 10^{4}$ células $/ \mathrm{ml}$ e pré-incubadas por 24 horas em estufa a $37^{\circ} \mathrm{C}$ ( $5 \%$ de $\mathrm{CO}^{2}$ e $100 \%$ umidade relativa). Após as 24 horas as células foram tratadas com $300 \mu \mathrm{l} /$ poço de diferentes diluições da subfração Acetato de etila III, duas vezes concentrados, a fim de se alcançar a concentração final desejada (5 $\mu \mathrm{g}, 10 \mu \mathrm{g}, 30 \mu \mathrm{g}$ ).

As células foram incubadas por mais 12 e 24 horas. Após esse período foram tripsinizadas, processo que neutraliza a adesão das células ao substrato (garrafa ou placa de cultura) possibilitando que se soltem. O processo consistiu na lavagem da cultura uma vez com PBS, para remoção do meio de cultura, incubação com tripsinaEDTA $0,25 \%$ em PBS, por aproximadamente 5 minutos a $37^{\circ} \mathrm{C}$. Após a incubação, foi adicionado meio RPMI-1640 com 10\% soro fetal bovino para inativação da tripsina, as células foram centrifugadas a 1200 RPM, por 10 minutos, ressuspendidas no meio e homogeneizadas vigorosamente com pipetador automático para dissolver os aglomerados celulares, finalmente fixou-se as células com glutaraldeído 2,5\% por no mínimo 2 horas.

Após a fixação, o material foi preparado para inclusão. As células foram lavadas três vezes com solução salina $0.9 \%$, sendo então colocada solução de ósmio 1\%, que permaneceu por 24 horas. As células foram lavadas três vezes com solução salina $0,9 \%$, após o qual permaneceram por 24 horas em solução de acetato de uranila $0,5 \%$. A seguir foram realizadas as etapas de desidratação, inclusão e emblocamento.

A desidratação do material foi feita com quantidades crescentes de acetona em água tridestilada conforme tabela 4.1 . 
Tabela 4.1 - Protocolo de desidratação do material

\begin{tabular}{c|c|c}
$\begin{array}{c}\text { Concentração } \\
\text { acetona tridestilada }\end{array}$ & $\begin{array}{c}\text { Número de banhos } \\
\text { em água }\end{array}$ & Tempo de permanecia \\
\hline $\mathbf{3 0 \%}$ & Um & 10 minutos \\
\hline $\mathbf{5 0 \%}$ & Um & 10 minutos \\
\hline $\mathbf{7 0} \%$ & Um & 10 minutos \\
\hline $\mathbf{9 0 \%}$ & Um & 10 minutos \\
\hline $\mathbf{1 0 0 \%}$ & Três & 10 minutos cada banho \\
\hline
\end{tabular}

O processo de substituição e inclusão foi feito com concentrações crescentes de resina de inclusão (Araldite 502) em acetona, sob agitação, conforme tabela 4.2.

Tabela 4.2 - Proporção acetona: resina de inclusão

\begin{tabular}{c|c} 
Proporção acetona: resina de & Tempo de permanência \\
inclusão & 1 hora \\
\hline $3: 1$ & $1 \mathrm{hora}$ \\
\hline $1: 1$ & 1 hora \\
\hline $1: 3$ &
\end{tabular}

Após a última troca, o material foi colocado em resina para inclusão pura, permanecendo em estufa a $37^{0} \mathrm{C}$ por uma hora. A seguir, o material foi colocado em formas de inclusão e preenchidas com resina permanecendo em estufa a $60^{\circ} \mathrm{C}$ por 72 horas. Foram obtidos cortes ultrafinos para observação em microscópio eletrônico de transmissão, porém os cortes foram analisados em microscópio óptico Nikon Eclipse E800. As imagens foram obtidas com o auxílio do software Image-Pro Plus versão 4.5 (Media Cybernetics-EUA).

4.8 Tratamento in vivo durante sete dias

Os animais foram divididos em dois grupos, grupo controle e grupo que recebeu a subfração Acetato de etila III, compostos por 10 animais cada grupo. Estes animais 
foram inoculados com $200 \mu \mathrm{l}$ de células viáveis do melanoma B16F10 (1,5 x $10^{5}$ /animal) por via subcutânea, na região lombar dorsal.

Após 10 dias do desenvolvimento tumoral começou-se o tratamento diário por sete dias com a subfração Acetato de etila III, na concentração de $5 \mathrm{mg} / \mathrm{kg}$ em um volume final de $100 \mu \mathrm{l}$ intratumoral, resultando em 7 doses no final do teste. $O$ grupo controle recebeu $100 \mu \mathrm{l}$ de salina e tween 80 a 0,1\% intratumoral, a mesma concentração que foi utilizada para a diluição da subfração.

Após os sete dias de tratamento os animais foram eutanasiados pela administração intraperitoneal do anestésico Tiopental e a análise macroscópica foi realizada. Fragmentos de fígado, baço, rim, pulmão, coração, estômago, intestino delgado e sistema nervoso foram fixados em formol $10 \%$, rotineiramente processados e incluídos em parafina. Cortes de $5 \mu \mathrm{m}$ de espessura foram obtidos para confecção de lâminas, e coradas em hematoxilina-eosina para análise histopatológica.

\subsection{Tratamento in vivo em dias alternados}

Os animais foram divididos em dois grupos, grupo controle e grupo que recebeu a subfração Acetato de etila III, compostos por 10 animais cada grupo. Estes animais foram inoculados com $200 \mu \mathrm{l}$ de células viáveis do melanoma B16F10 (1,5 x $10 \%$ /animal) por via subcutânea, na região lombar dorsal.

A região onde foram inoculadas as células do melanoma foi depilada e demarcada. Decorridos 48 horas da inoculação começou-se o tratamento em dias alternados: a cada dois dias os animais recebiam tratamento intratumoral com a dose padrão utilizada $(5 \mathrm{mg} / \mathrm{kg})$, ao termino os animais receberam 7 doses da subfração Acetato de etila III.

Após dezenove dias de tratamento em dias alternados, os animais foram eutanasiados pela administração intraperitoneal de anestésico Tiopental e realizada a analise macroscópica. Fragmentos de fígado, baço, rim, pulmão, coração, estômago, intestino delgado e sistema nervoso foram fixados em formol $10 \%$, rotineiramente processados e incluídos em parafina. Cortes de $5 \mu \mathrm{m}$ de espessura foram obtidos 
para confecção de lâminas, e coradas em hematoxilina-eosina para análise histopatológica.

\subsection{Tratamento precoce}

Os animais foram divididos em dois grupos, grupo controle e grupo que recebeu a subfração Acetato de etila III, compostos por 10 animais cada grupo. Estes animais foram inoculados com $200 \mu \mathrm{l}$ de células viáveis do melanoma B16F10 (1,5 x 105 /animal) por via subcutânea, na região lombar dorsal.

Após a inoculação esperou-se cinco minutos para a absorção da suspensão celular e no mesmo local da inoculação foi aplicado o tratamento com a subfração Acetato de etila III $(5 \mathrm{mg} / \mathrm{kg})$, os animais receberam dose única da subfração Acetato de Etilalll.

Após dezenove dias do tratamento, os animais foram eutanasiados pela administração intraperitoneal de anestésico Tiopental e realizada a analise macroscópica. Fragmentos de fígado, baço, rim, pulmão, coração, estômago, intestino delgado e sistema nervoso foram fixados em formol $10 \%$, rotineiramente processados e incluídos em parafina. Cortes de $5 \mu \mathrm{m}$ de espessura foram obtidos para confecção de lâminas, e coradas em hematoxilina-eosina para análise histopatológica.

\subsection{Cálculo do volume tumoral}

Ao final de cada tratamento no dia da eutanásia dos animais o volume tumoral foi mensurado com auxilio de um micrometro.

Para o cálculo do volume tumoral utilizou-se a formula do volume da elipse, segundo Biondi 2006 
$V=L^{2} \mathrm{C} / 6$

$\mathrm{V}=$ volume $\mathrm{em} \mathrm{mm}^{3}$

$\mathrm{L}=$ largura do tumor tomada em seu maior eixo, $\mathrm{em} \mathrm{mm}^{3}$

$\mathrm{C}=$ comprimento do tumor tomando em seu maior eixo,

\subsection{Análise estatística}

Os dados obtidos dos experimentos foram avaliados com o teste estatístico de análise de variância (ANOVA), com nível de significância de $1 \% \quad(p<0,0001)$, utilizando-se o pós-teste e pós-teste Dunnett. para a identificação de possíveis diferenças entre os grupos. 


\section{$5 \quad$ RESULTADOS}

5.1 Rendimento dos extratos

A partir de $8,319 \mathrm{Kg}$ de partes aéreas flores e folhas de Vernonia scorpioides foram obtidos 18 litros de extrato hidroalcóolico. Após extração do álcool pelo rotaevaporador foram obtidos 2 litros de extrato bruto ao qual foi submetido a partições líquido-líquido subseqüentes, obtendo-se 136,48g de subfração diclorometano I, $83,82 \mathrm{~g}$ de subfração diclorometano II, e finalmente $10,51 \mathrm{~g}$ de Acetato de etila III, conforme figura 4.

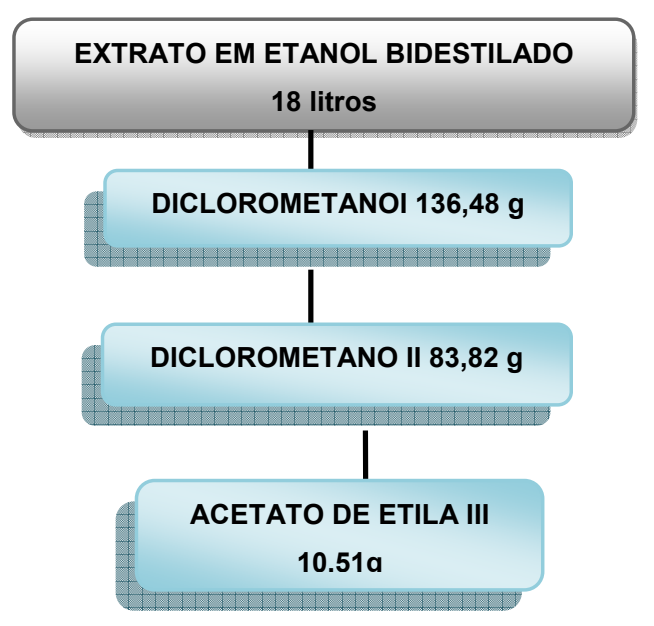

Figura 4 - Fluxograma do rendimento das subfrações

\subsection{Ensaio de citotoxicidade}

As células de melanoma murino B16F10 em cultura têm característica fibroblastóides, crescendo aderidas à superfície da garrafa de forma espraiada, e, podendo crescer umas sobre as outras. 
5.2.1 Tratamento com a subfração acetato de etila III de Vernonia scorpioides por 24 horas.

As células foram tratadas com a subfração acetato de etila III nas

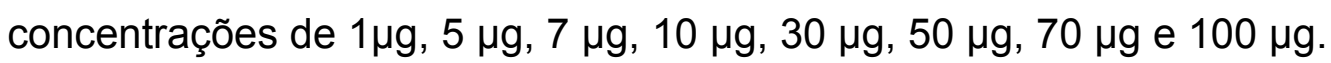

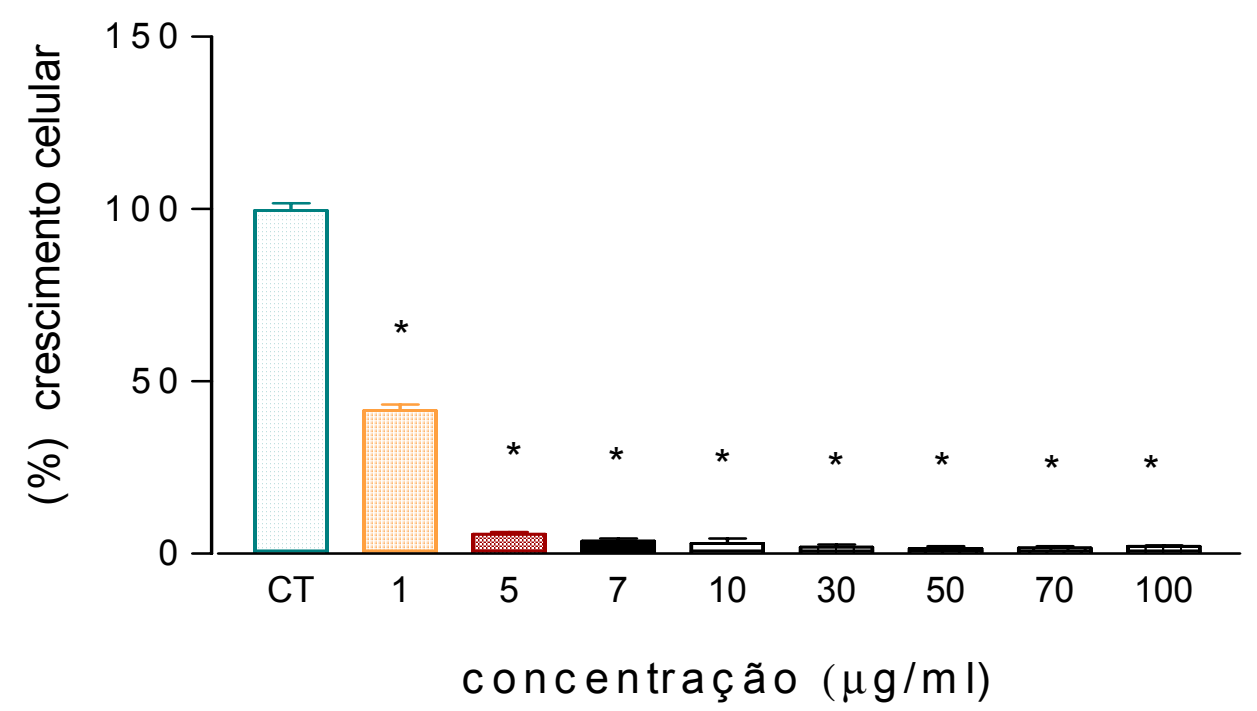

Figura 5 - Gráfico do crescimento de células de melanoma B16F10 após tratamento por $24 \mathrm{~h}$ com várias concentrações da subfração acetato etila III de Vernonia scorpioides. Teste estatístico ANOVA $(p<0,0001)$ e pós-teste Dunnett. * $p<0,01$ representa o nível de significância em relação ao controle
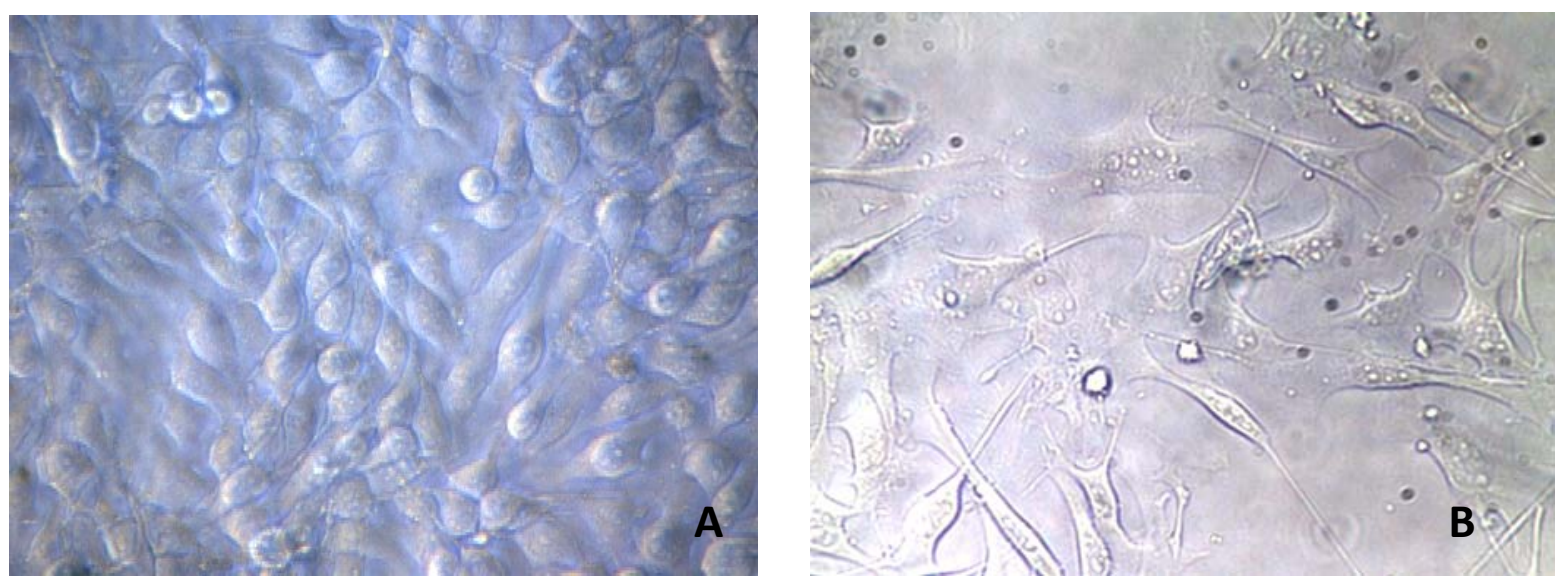

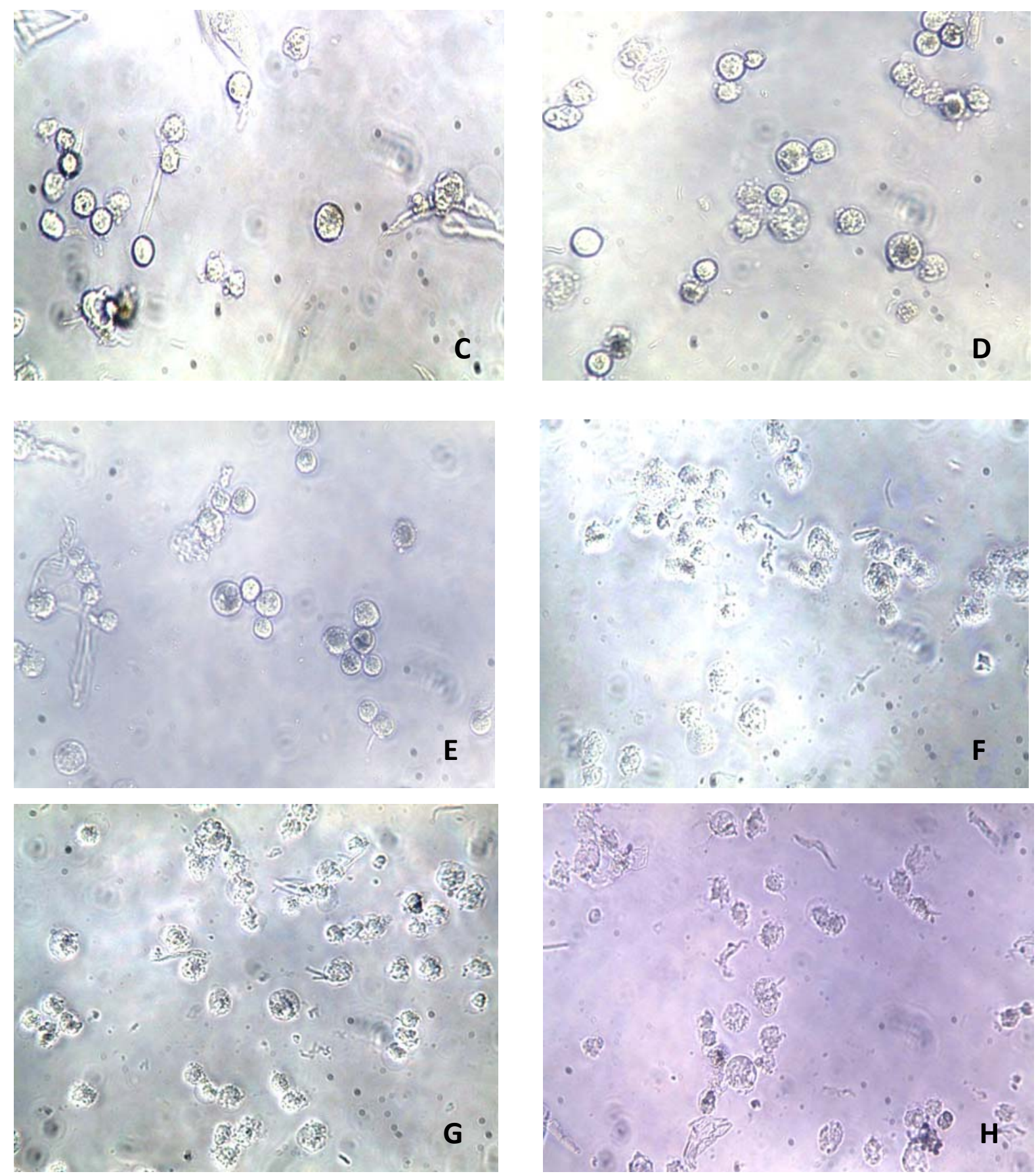

Figura 6 - Cultivo de células B16F10 in vitro com exposição à subfração acetato de etila III por 24 horas. (A) grupo controle com $0,1 \%$ de tween 80 , grupos tratados com subfração Acetato de etila III $1 \mu \mathrm{g}(\mathrm{B}), 5 \mu \mathrm{g}(\mathrm{C}), 7$ $\mu g(D), 10 \mu g(E), 30 \mu g(F), 50 \mu g(G)$ e $70 \mu g(H)$. Notar que as alterações celulares começam a ocorrer a partir do tratamento com concentração de $5 \mu \mathrm{g} / \mathrm{ml}$, permanecendo o tratamento com $1 \mu \mathrm{g} / \mathrm{ml}$ semelhante ao controle. Em concentrações maiores pode-se observar perda da morfologia celular normal, e aumento de debris celulares. Objetiva 40x 
Ao término do tratamento de 24 horas todas as concentrações apresentaram ser significativamente diferentes do grupo controle conforme figura 5 , as células do grupo controle permaneceram vivas, mantinham-se em crescimento normal, aderidas ao substrato bem esticadas mantendo aparência brilhosa, permaneciam coesas, formando um tapete de células sem muitos espaços entre uma e outra conforme figura $6(\mathrm{~A})$, o grupo que recebeu $1 \mu \mathrm{g}$ da subfração apresentou quantidade de células vivas diferentes quando comparadas aos grupos controle, conforme figura 5 e figura $6(\mathrm{~B})$, Os grupos que receberam tratamentos de $5 \mu \mathrm{g}, 7 \mu \mathrm{g}, 10 \mu \mathrm{g}$, $25 \mu \mathrm{g}, 50 \mu \mathrm{g}$ e $70 \mu \mathrm{g}$, apresentaram as mesmas características não ocorrendo crescimento celular, as células estavam todas mortas, com suas membranas prejudicadas e vários restos celulares no meio conforme figura $6(C),(D),(E),(F)$, $(\mathrm{G}),(\mathrm{H})$.

5.2.2 Tratamento com a subfração acetato etila III de Vernonia scorpioides por 48 horas

As células foram tratadas com a subfração acetato de etila III nas

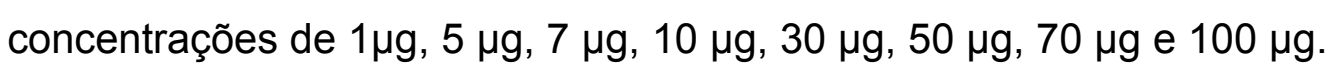

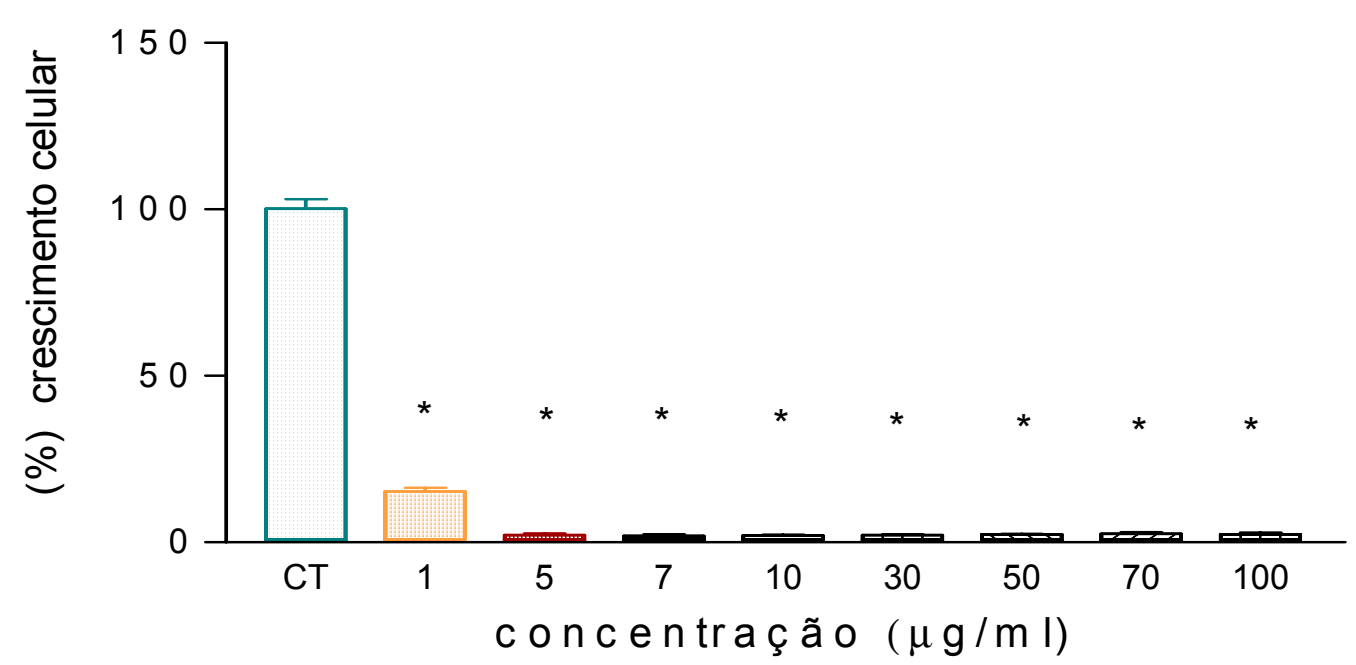

Figura 7 - Gráfico do crescimento de células de melanoma B16F10 após tratamento por $48 \mathrm{~h}$ com várias concentrações da subfração acetato de etila III de Vernonia scorpioides. Teste estatístico ANOVA $(p<0,0001)$ e pós-teste Dunnett. * $p<0,01$ representa o nível de significância em relação ao controle 

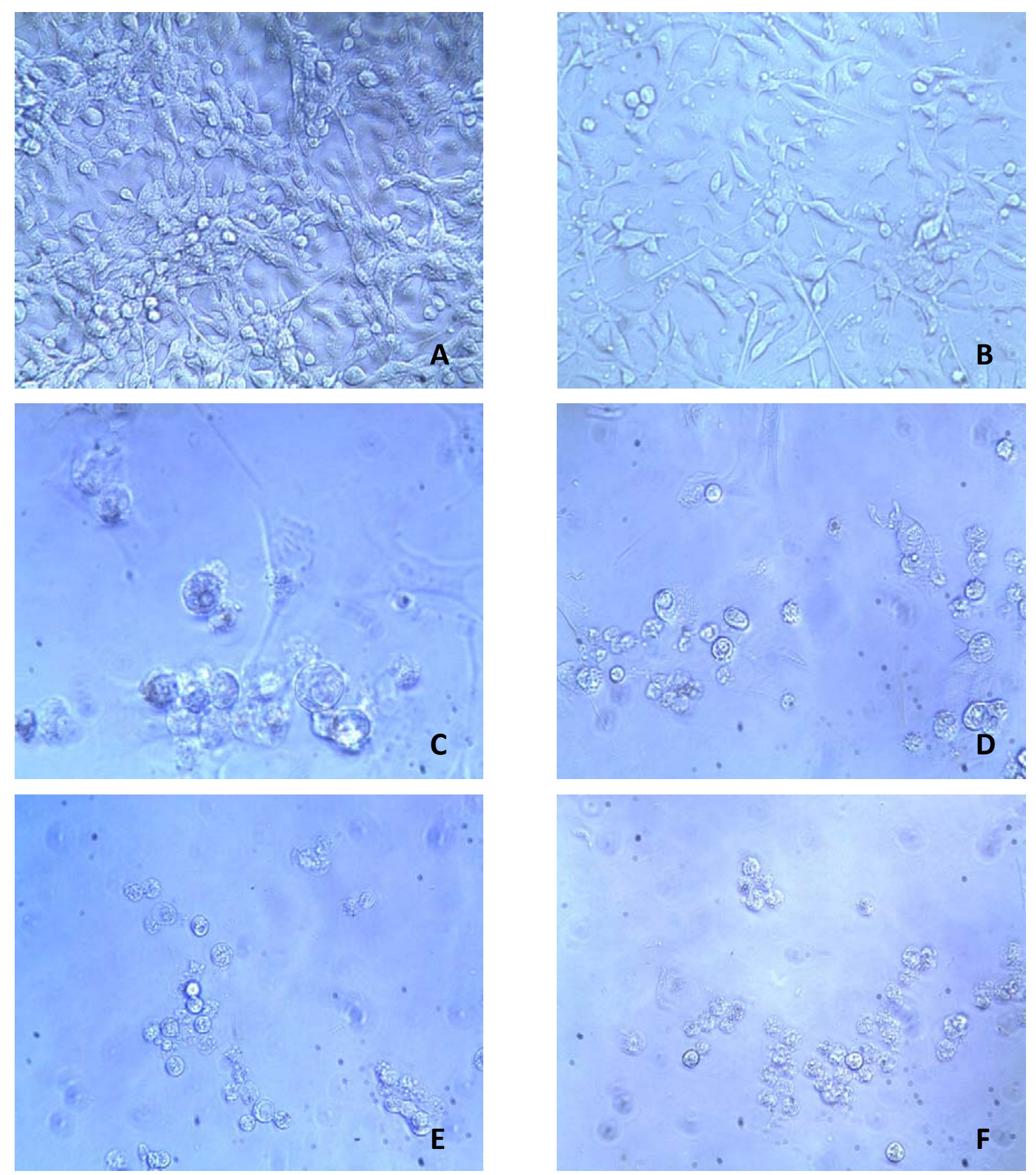

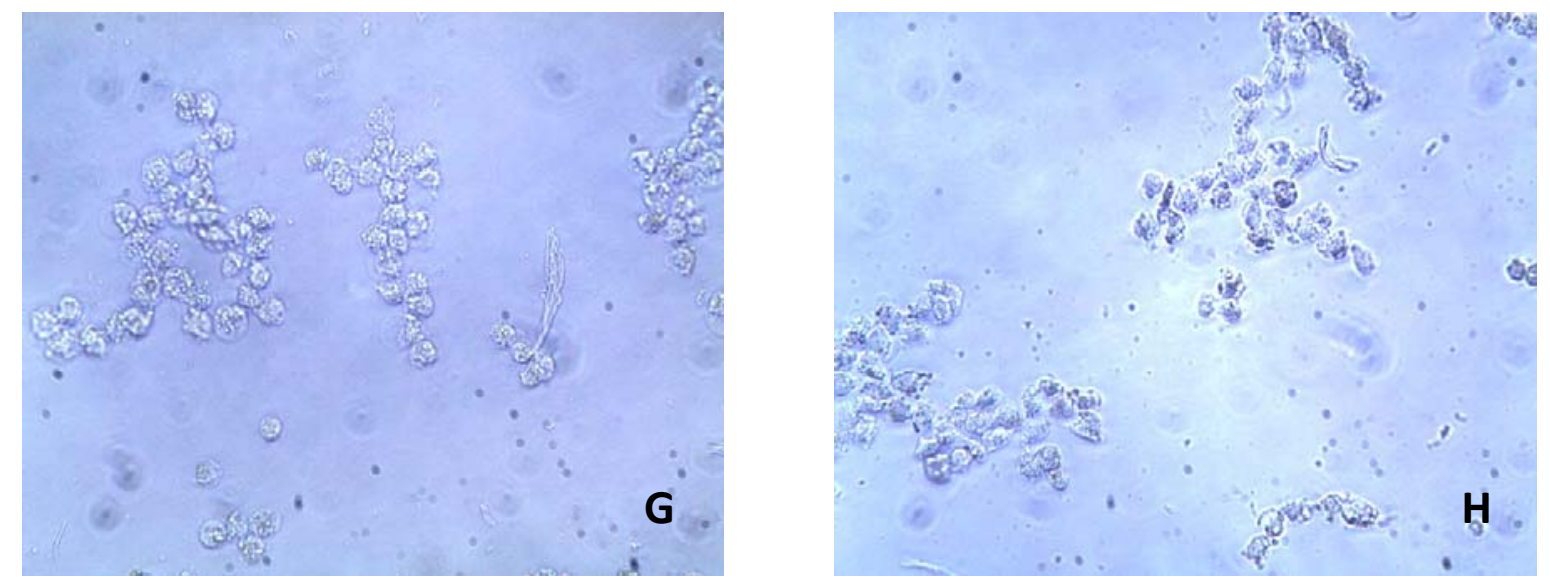

Figura 8 - Cultivo de células B16F10 in vitro com exposição à subfração acetato de etila III por 48 horas. (A) grupo controle com $0,1 \%$ de tween 80 , grupos tratados com subfração Acetato de etila III $1 \mu \mathrm{g}(\mathrm{B}), 5 \mu \mathrm{g}(\mathrm{C}), 7 \mu \mathrm{g}(\mathrm{D}), 10 \mu \mathrm{g}$ $(E), 30 \mu \mathrm{g}(\mathrm{F}), 50 \mu \mathrm{g}(\mathrm{G})$ e $100 \mu \mathrm{g}(\mathrm{H})$. Notar que as alterações celulares começam a ocorrer a partir do tratamento com concentração de $5 \mu \mathrm{g} / \mathrm{ml}$, permanecendo o tratamento com $1 \mu \mathrm{g} / \mathrm{ml}$ semelhante ao controle. Em concentrações maiores pode-se observar perda da morfologia celular normal, e aumento de debris celulares. Objetiva 20x.

Na figura 7 se analisa que ao término do tratamento de 48 horas todas as concentrações apresentaram serem significativamente diferentes do grupo controle, as células do grupo controle permaneceram vivas, mantinham-se em crescimento normal, aderidas ao substrato bem esticadas mantendo aparência brilhosa, permaneciam coesas, formando um tapete de células sem muitos espaços entre uma e outra conforme figura $8(A)$, o grupo que recebeu $1 \mu \mathrm{g}$ da subfração apresentou quantidade de células vivas diferentes quando comparadas aos grupos controle, a densidade celular reduzida quando comparada ao grupo controle, conforme visto nas figuras 7 e $8(B)$, Os grupos que receberam tratamentos de $5 \mu \mathrm{g}$, $7 \mu \mathrm{g}, 10 \mu \mathrm{g}, 25 \mu \mathrm{g}, 50 \mu \mathrm{g}$ e $100 \mu \mathrm{g}$, continham as mesmas características não ocorrendo crescimento celular, se verifica a elevada toxicidade, onde as células não estavam aderidas ao substrato, contraídas, o meio apresenta muitos restos celulares, demonstrando morte celular devido à alta toxicidade do subfração acetato de etila III de Vernonia scorpioides, conforme visto figura $8(C),(D),(E),(F),(G)$ e $(\mathrm{H})$. 
5.2.3 Tratamento com a subfração acetato etila III de Vernonia scorpioides por 72 horas

As células foram tratadas com a subfração acetato de etila III nas concentrações de $1 \mu \mathrm{g}, 5 \mu \mathrm{g}, 7 \mu \mathrm{g}, 10 \mu \mathrm{g}, 30 \mu \mathrm{g}, 50 \mu \mathrm{g}, 70 \mu \mathrm{g}$ e $100 \mu \mathrm{g}$.

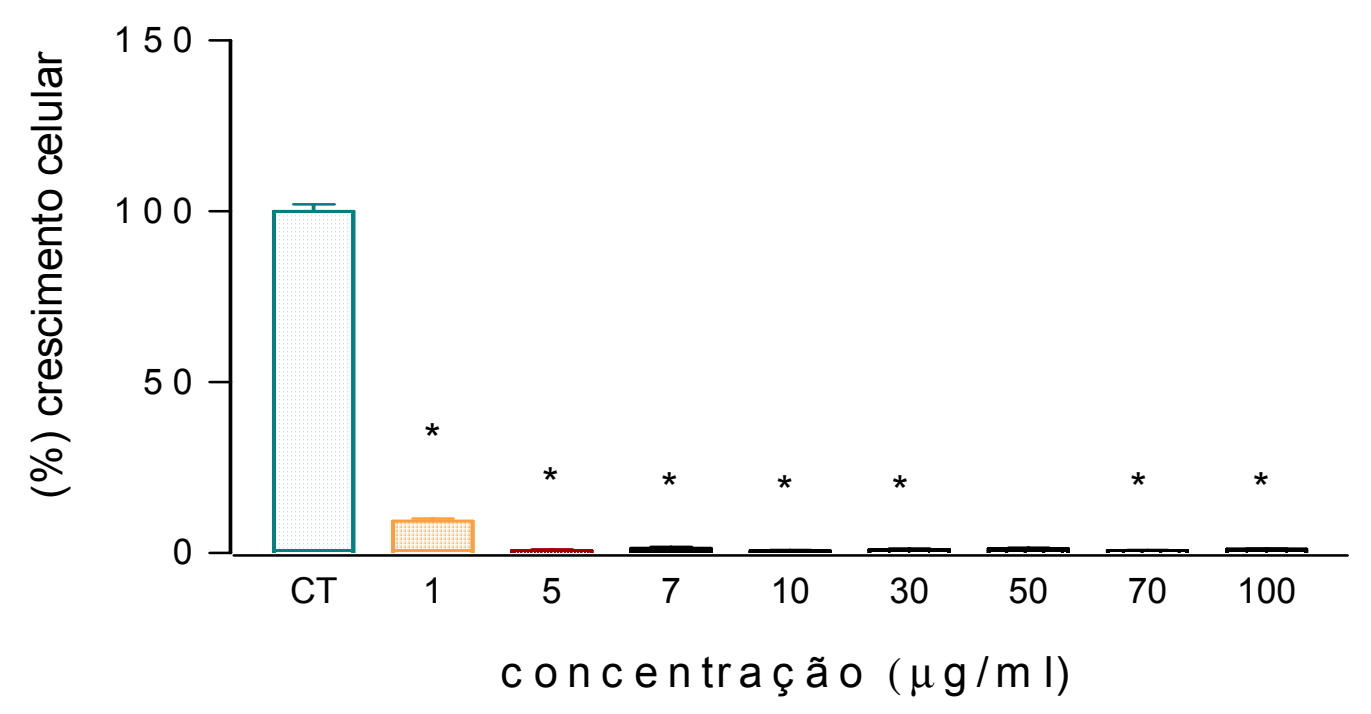

Figura 9 - Gráfico do crescimento de células de melanoma B16F10 após tratamento por $72 \mathrm{~h}$ com várias concentrações da subfração acetato etila III de Vernonia scorpioides. Teste estatístico ANOVA $(p<0,0001)$ e pós-teste Dunnett. * $p<0,01$ representa o nível de significância em relação ao controle 

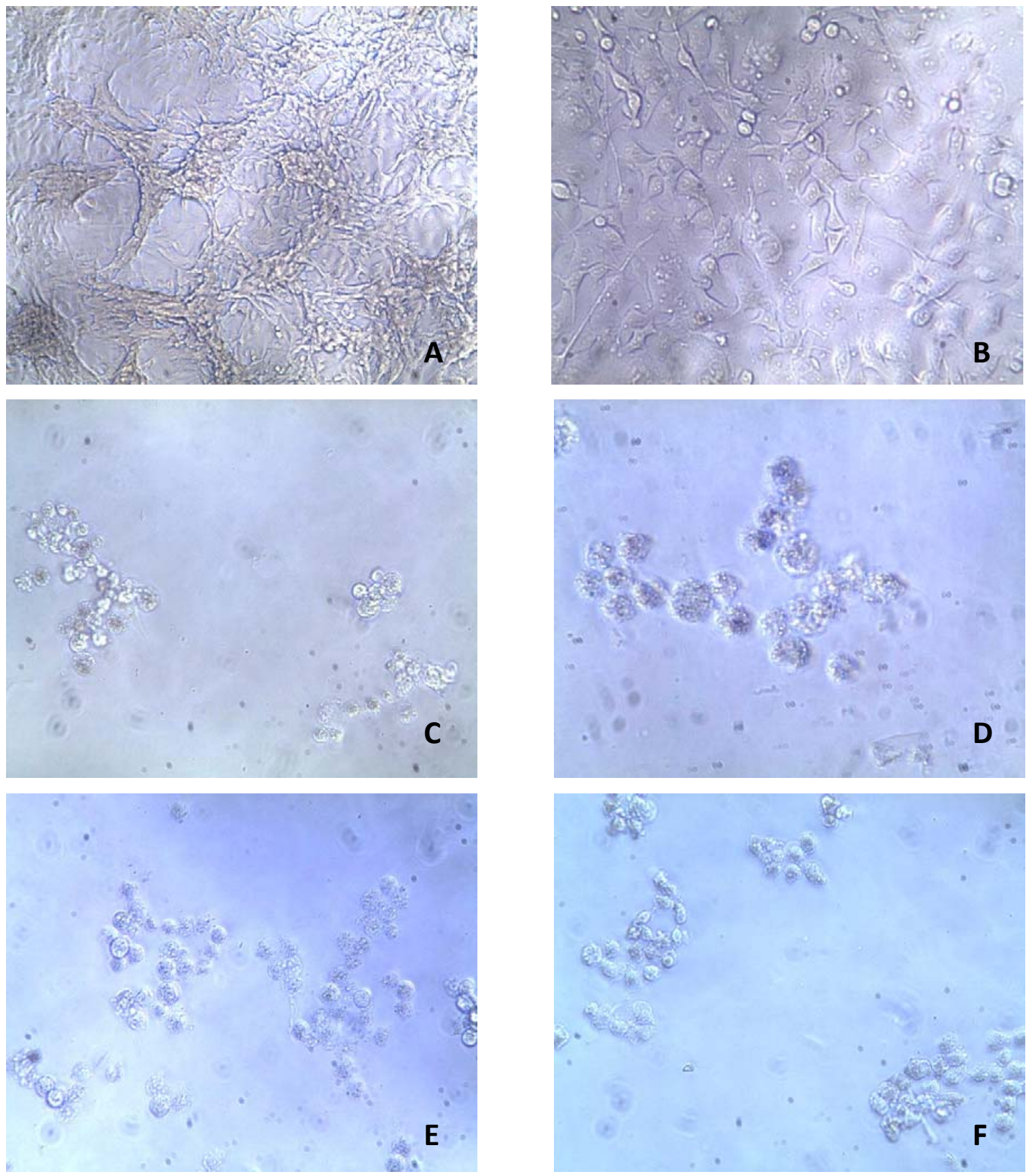

Figura 10 - Cultivo de células B16F10 in vitro com exposição à subfração acetato de etila III por 72 horas. (A) grupo controle com $0,1 \%$ de tween 80 , grupos tratados com subfração aceteto de etila III $1 \mu \mathrm{g}(\mathrm{B}), 5 \mu \mathrm{g}(\mathrm{C}), 7 \mu \mathrm{g}(\mathrm{D}), 10 \mu \mathrm{g}$ $(E)$ e $100 \mu \mathrm{g}(\mathrm{F})$. Notar que as alterações celulares começam a ocorrer a partir do tratamento com concentração de $5 \mu \mathrm{g} / \mathrm{ml}$, permanecendo o tratamento com $1 \mu \mathrm{g} / \mathrm{ml}$ semelhante ao controle. Em concentrações maiores pode-se observar perda da morfologia celular normal, e aumento de debris celulares. Objetiva $20 x$ 
A figura 9 mostra que após exposição das células a subfração acetato de etila III de Vernonia scorpioides por um período de 72 horas, ocorreu o crescimento normal do grupo controle conforme figura 10 (A), o grupo exposto a concentração $1 \mu \mathrm{g}$ não apresentou um crescimento celular elevado mantendo viva as células já existentes, demonstrando citotoxicidade muito leve nas células conforme figura 10 (B). As concentrações de $5 \mu \mathrm{g}, 7 \mu \mathrm{g}, 10 \mu \mathrm{g}, 25 \mu \mathrm{g}, 50 \mu \mathrm{g}, 70 \mu \mathrm{g}$ e $100 \mu \mathrm{g}$ mostraram elevada toxicidade, onde as células não estavam aderidas ao substrato, se apresentavam contraídas, o meio apresenta muitos restos celulares, causando morte celular devido à alta toxicidade do subfração acetato III de Vernonia scorpioides conforme figura 10 (C), (D), (E) e (F) se pode ver as concentrações de $5 \mu \mathrm{g}, 7 \mu \mathrm{g}, 10 \mu \mathrm{g}$ e $100 \mu \mathrm{g}$.

5.2.4 Tratamento com a subfração acetato de etila III de Vernonia scorpioides por 96 horas.

As células foram tratadas com a subfração acetato de etila III nas

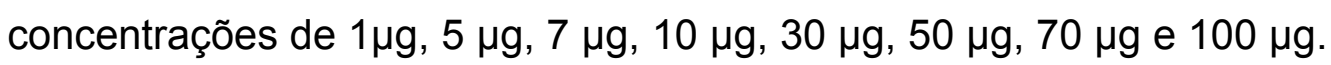

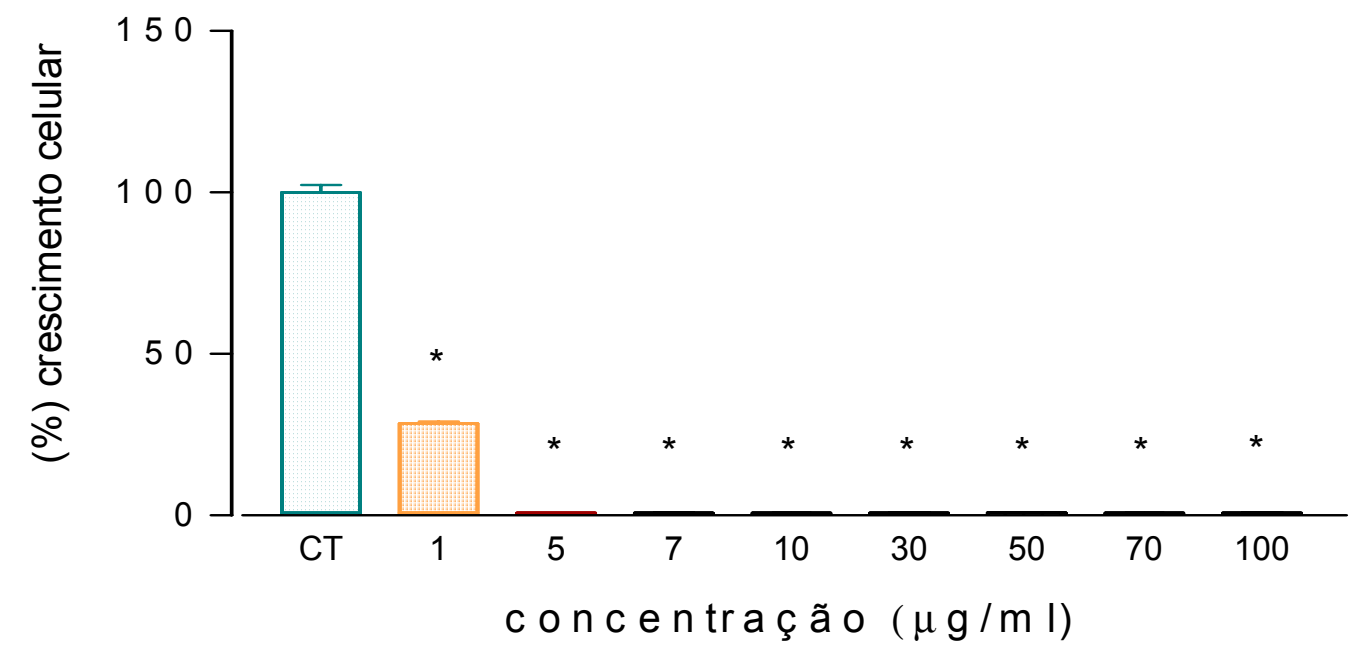

Figura 11 - Gráfico do crescimento de células de melanoma B16F10 após tratamento por 96h com várias concentrações da subfração acetato de etila III de Vernonia scorpioides. Teste estatístico ANOVA $(p<0,0001)$ e pós-teste Dunnett. * $p<0,01$ representa o nível de significância em relação ao controle 

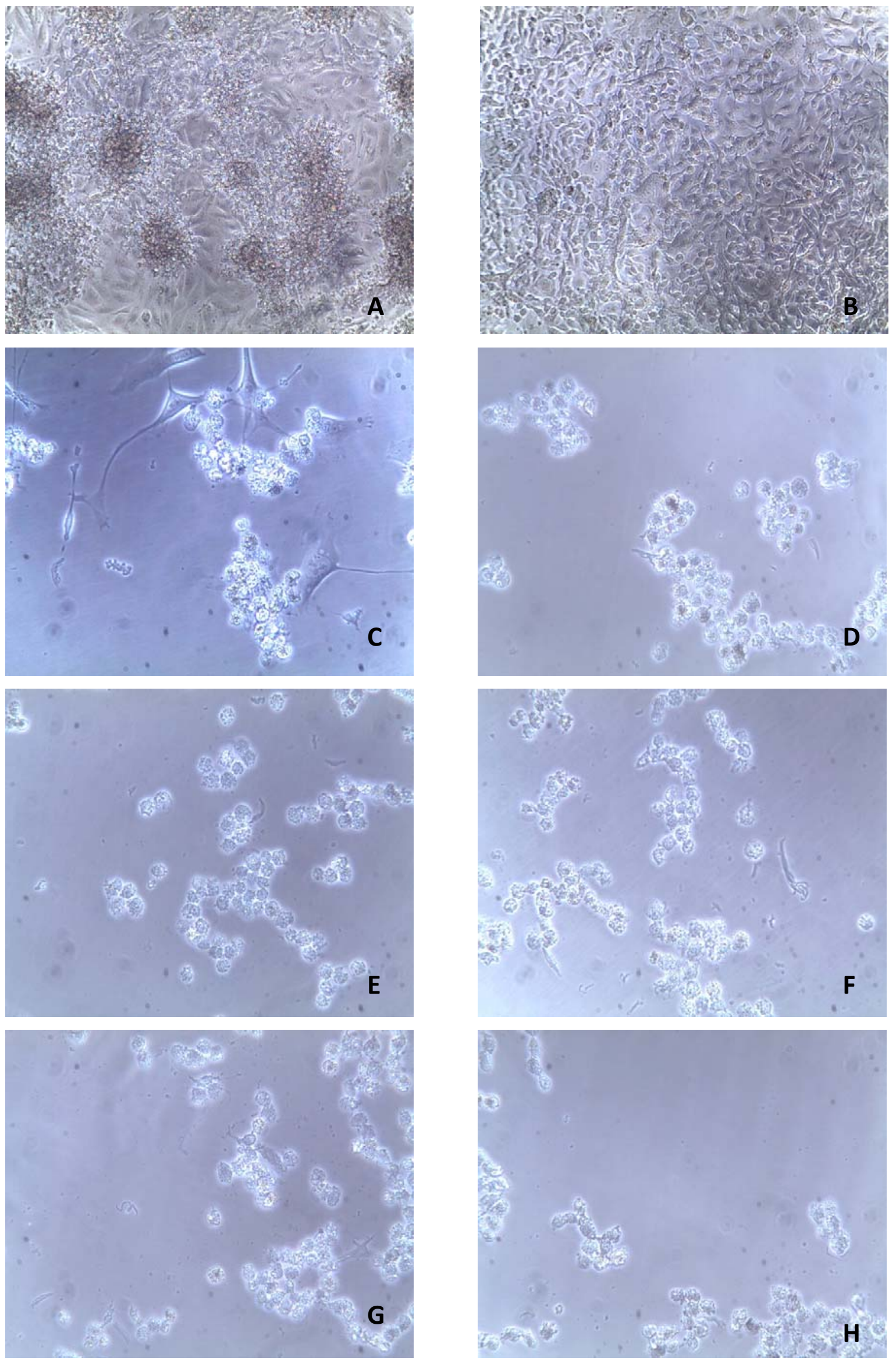


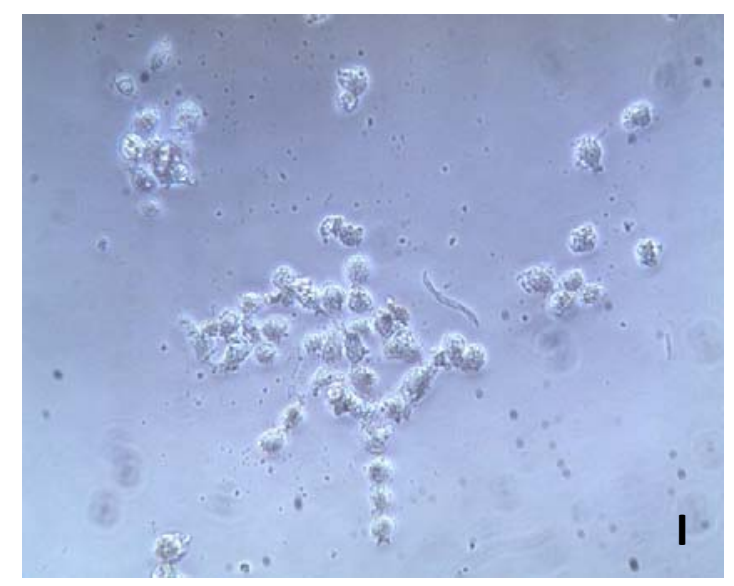

Figura 12 - Cultivo de células B16F10 in vitro com exposição à subfração acetato de etila III por 96 horas. (A) grupo controle com $0,1 \%$ de tween 80 , grupos tratados com subfração acetato de etila III $1 \mu \mathrm{g}(\mathrm{B}), 5 \mu \mathrm{g}(\mathrm{C}), 7 \mu \mathrm{g}(\mathrm{D})$,

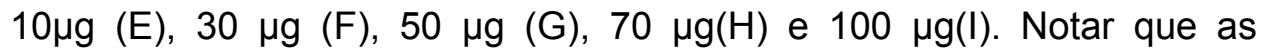
alterações celulares começam a ocorrer a partir do tratamento com concentração de $5 \mu \mathrm{g} / \mathrm{ml}$, permanecendo o tratamento com $1 \mu \mathrm{g} / \mathrm{ml}$ semelhante ao controle. Em concentrações maiores pode-se observar perda da morfologia celular normal, e aumento de debris celulares. Objetiva 20x

Após as 96 horas de exposição das células a subfração acetato de etila III de Vernonia scorpioides (figura 11) todas as concentrações apresentaram ser significativamente diferentes do grupo controle, as células do grupo controle permaneceram vivas, mantinham-se em crescimento normal, aderidas ao substrato bem esticadas mantendo aparência brilhosa, permaneciam coesas, formando um tapete de células sem muitos espaços entre uma e outra, aglomerados celulares (Figura $12(\mathrm{~A})$ ), o grupo de $1 \mathrm{\mu g} / \mathrm{ml}$ apresentou crescimento celular, porém menor a densidade celular também esta reduzida em comparação ao grupo controle (Figura 11 e figura 12 (B)), as concentrações de $5 \mu \mathrm{g}, 7 \mu \mathrm{g}, 10 \mu \mathrm{g}, 25 \mu \mathrm{g}, 50 \mu \mathrm{g}, 70 \mu \mathrm{g}$ e $100 \mu \mathrm{g}$ mostraram elevada toxicidade, onde as células não estavam aderidas ao substrato, apresentavam-se contraídas, muitos restos celulares no meio, demonstrando morte celular devido a alta toxicidade do subfração acetato de etila III de Vernonia scorpioides. Figura $12(C),(D),(E),(F),(G),(H)$ e (I). 
5.2.5 Densidade óptica dos tratamentos com a subfração acetato de etila III de Vernonia scorpioides ao longo do tempo

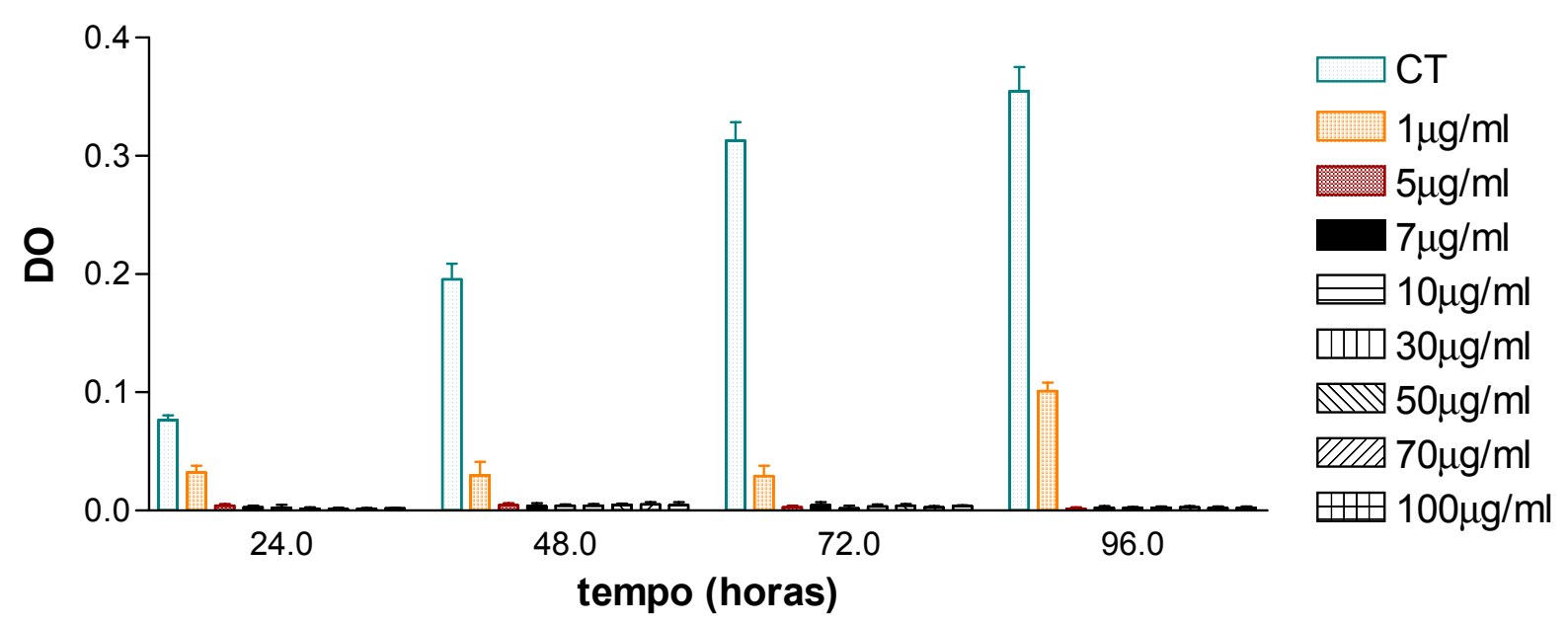

Figura 13 - Densidade óptica de células B16F10 tratadas com diversas concentrações da subfração acetato de etila III de Vernonia scorpioides por 24, 48, 72 e 96 horas. Em 96 horas observa-se um aumento da densidade óptica da concentração de $1 \mu \mathrm{g} / \mathrm{ml}$ um indicativo de aumento da proliferação celular.

Como se pode observar na figura 13, um comparativo da densidade óptica do ensaio de citotoxicidade entre diferentes horas de tratamento 24, 48, 72 e 96 horas, as células tratadas com a concentração de $1 \mu \mathrm{g} / \mathrm{ml}$ permaneceram no mesmo nível de crescimento, porém menores quando comparadas ao grupo controle, nota-se uma diferença do crescimento entre 72 e 96 horas de tratamento, apesar de ter ocorrido morte celular as células continuaram em proliferação aumentando a quantidade de células .

5. 4 Detecção de morte celular - Laranja de acridina e brometo de etídio

Para verificar a possibilidade de morte celular, a técnica de laranja de acridina/ brometo de etídio foi realizada. Sendo a laranja de acridina um corante vital, corando as células vivas em verde. As células mortas são coradas pelo brometo de etídio em 
vermelho, que só penetra em células com alteração de permeabilidade celular (SPECTOR, 1998).

Para determinar se ocorre morte celular logo no início do tratamento, o teste foi realizado nos seguintes tempos: 1, 6, 12 e 24 horas. As concentrações utilizadas foram 1, 5, 25 e $50 \mu \mathrm{g} / \mathrm{ml}$ da subfração acetato de etila III de Vernonia scorpioides.

Pode-se observar na figura 14 que após uma hora de exposição, o tratamento com $1 \mu \mathrm{g} / \mathrm{ml}$ não produziu efeitos evidentes em relação ao grupo controle (figura 14(C), (A) e (B). No tratamento com $5 \mu \mathrm{g} / \mathrm{ml}$, as diferenças em relação ao grupo controle começam a surgir, com presença de células mortas adjacentes às células vivas (figura 14 (D)). $O$ tratamento com concentrações mais altas $(25$ e $50 \mu \mathrm{g} / \mathrm{ml}$ ) resultou em maior número de células mortas e células com alterações morfológicas em membrana citoplasmática figura $14(E)$ e $(F)$.

Após 6 horas de exposição à subfração acetato de etila III, é possível observar um evidente efeito citotóxico na concentração mais baixa de $1 \mu \mathrm{g} / \mathrm{ml}$. Nota-se um aumento de células mortas, alterações morfológicas nas células (células arredondadas) e redução da densidade celular em relação ao controle (figura 15 (C)). Os tratamentos com concentrações maiores $(5,25$ e $50 \mu \mathrm{g} / \mathrm{ml})$ provocaram morte de todas as células (figura $15(D),(E)$ e $(F)$ ).

Com 12 e 24 horas de exposição, o padrão de resposta ao tratamento se mantém semelhante ao tempo de 6 horas, ou seja, o tratamento com $1 \mu \mathrm{g} / \mathrm{ml}$ apresenta células mortas, densidade celular diminuída e persiste a alteração morfológica (figura $16(\mathrm{C})$ e $17(\mathrm{C})$ ). Nas concentrações maiores $(5,25$ e $50 \mu \mathrm{g} / \mathrm{ml}$ ) as células estão todas mortas. Figuras 16 (D, E e F) e 17(D, E e F)). 

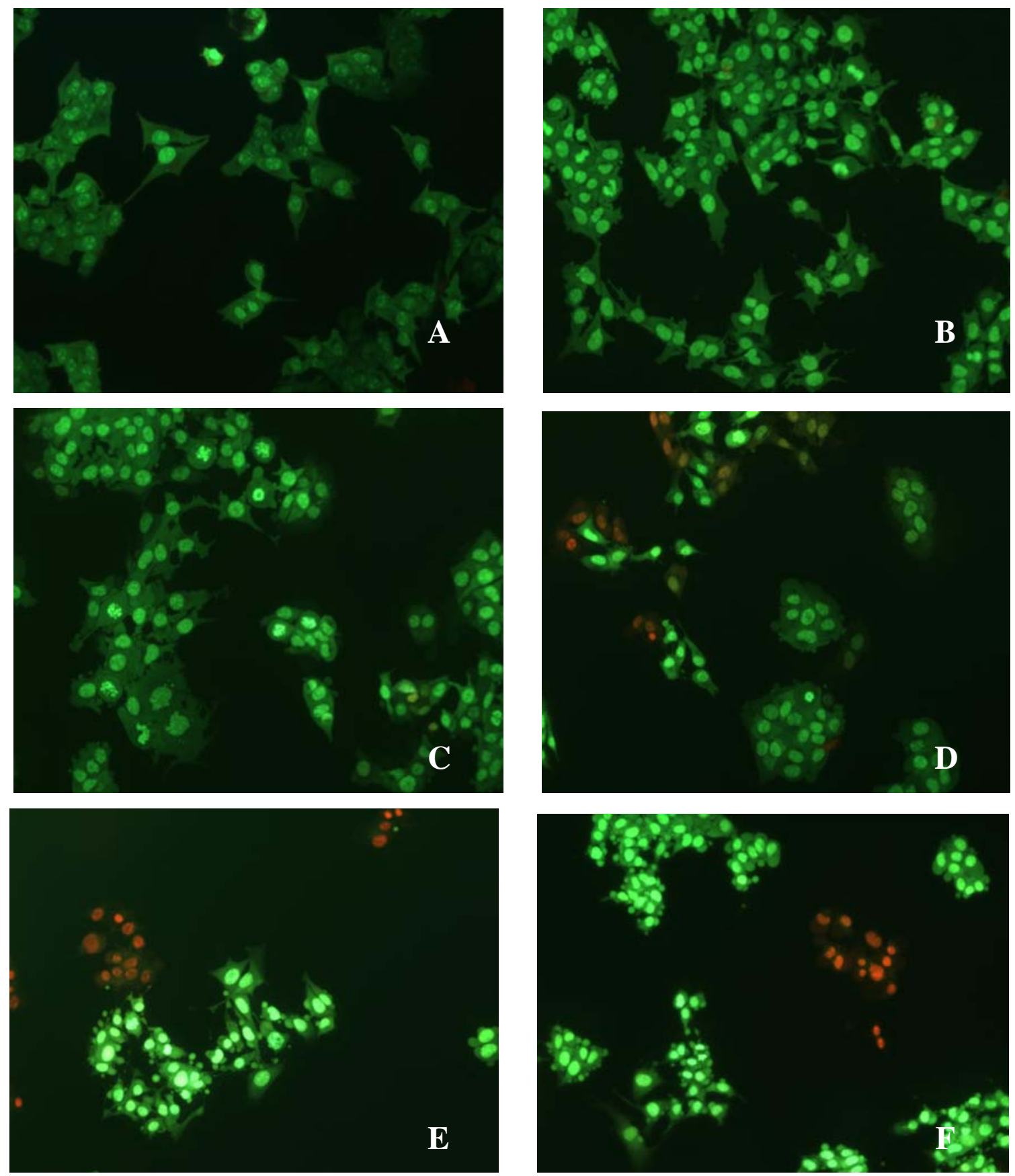

Figura 14 - Detecção de morte celular por fluorescência utilizando a técnica da laranja de acridina/brometo de etídio. As células foram expostas por 1 hora à subfração acetato de etila III de Vernonia scorpioides. (A) controle; (B) controle com 0,1\% tween; (C) tratamento de $1 \mu \mathrm{g} / \mathrm{ml}$; (D) tratamento de $5 \mu \mathrm{g} / \mathrm{ml}$. Pode-se notar a presença de células mortas; Os tratamentos de $25 \mu \mathrm{g} / \mathrm{ml}(\mathrm{E})$ e de $50 \mu \mathrm{g} / \mathrm{ml}(\mathrm{F})$ apresentam grupos de células mortas e alterações na morfologia celular. Objetiva de 10x 

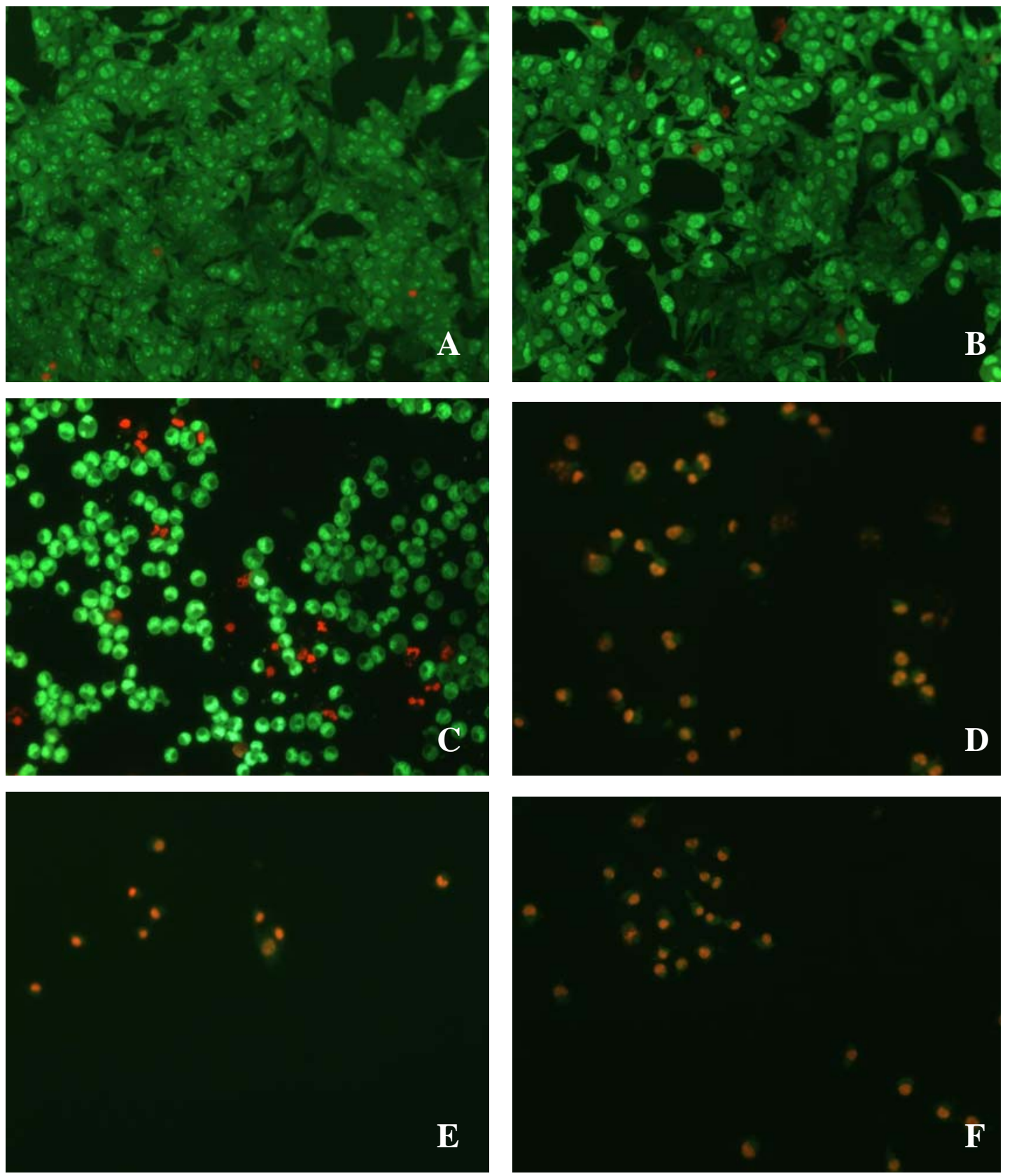

Figura 15 - Detecção de morte celular por fluorescência utilizando a técnica da laranja de acridina/brometo de etídio. As células foram expostas por 6 horas à subfração acetato de etila III de Vernonia scorpioides. (A) controle; (B) controle com 0,1\% tween; (C) tratamento de $1 \mu \mathrm{g} / \mathrm{ml}$. Observar a presença de células mortas e alteração de morfologia celular; Os tratamentos de $5 \mu \mathrm{g} / \mathrm{ml}$ (D), $25 \mu \mathrm{g} / \mathrm{ml}$ (E) e de $50 \mu \mathrm{g} / \mathrm{ml}(\mathrm{F})$ provocaram morte de todas as células. Objetiva de $10 \mathrm{x}$ 

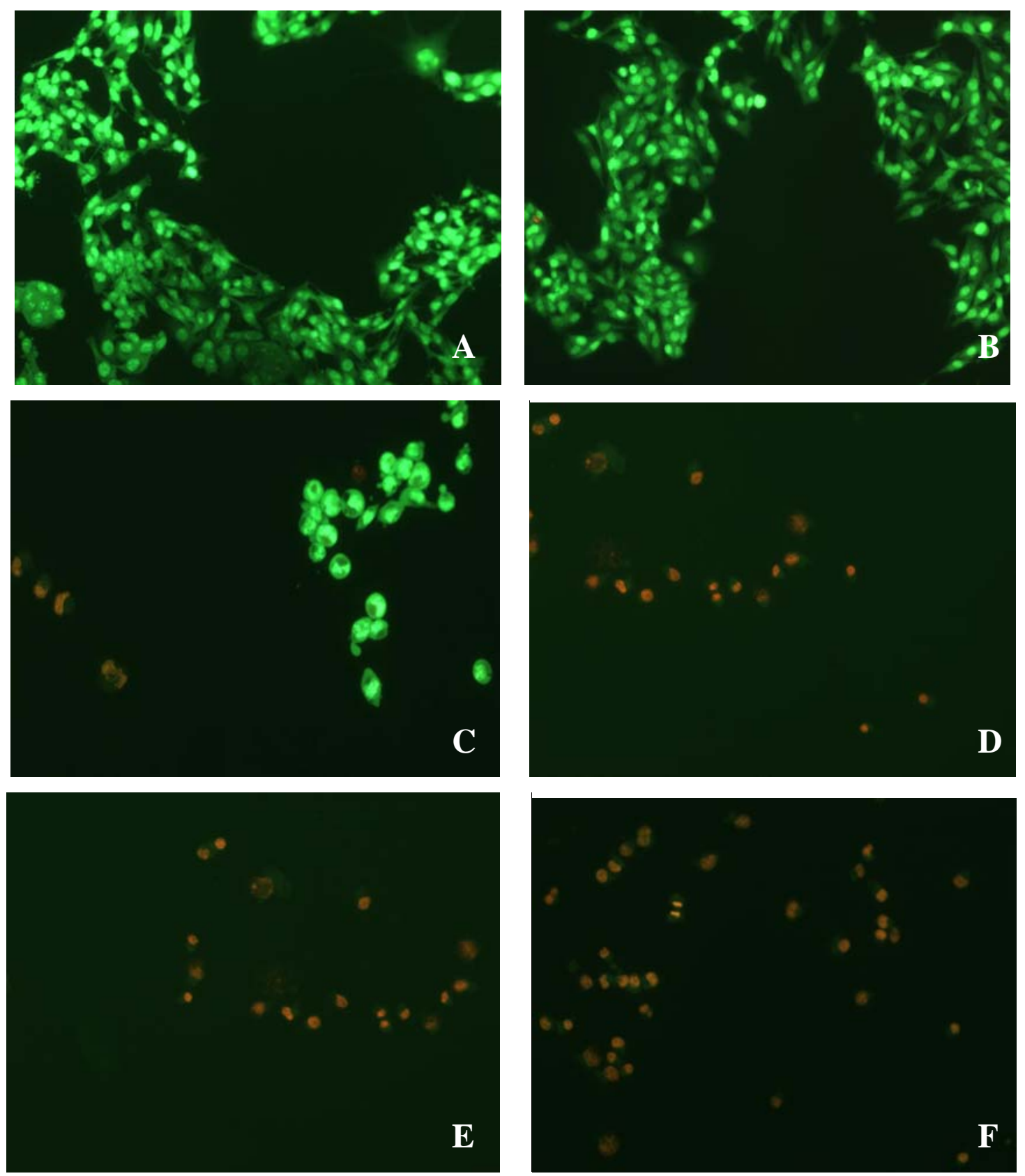

Figura 16 - Detecção de morte celular por fluorescência utilizando a técnica da laranja de acridina/brometo de etídio. As células foram expostas por 12 horas à subfração acetato de etila III de Vernonia scorpioides. (A) controle; (B) controle com 0,1\% tween; (C) tratamento de $1 \mu \mathrm{g} / \mathrm{ml}$. Observar a redução da densidade celular, presença de células mortas e alteração de morfologia celular; Os tratamentos de $5 \mu \mathrm{g} / \mathrm{ml}$ (D), 25 $\mu \mathrm{g} / \mathrm{ml}(\mathrm{E})$ e de $50 \mu \mathrm{g} / \mathrm{ml}(\mathrm{F})$ provocaram morte de todas as células. Objetiva de 10x 

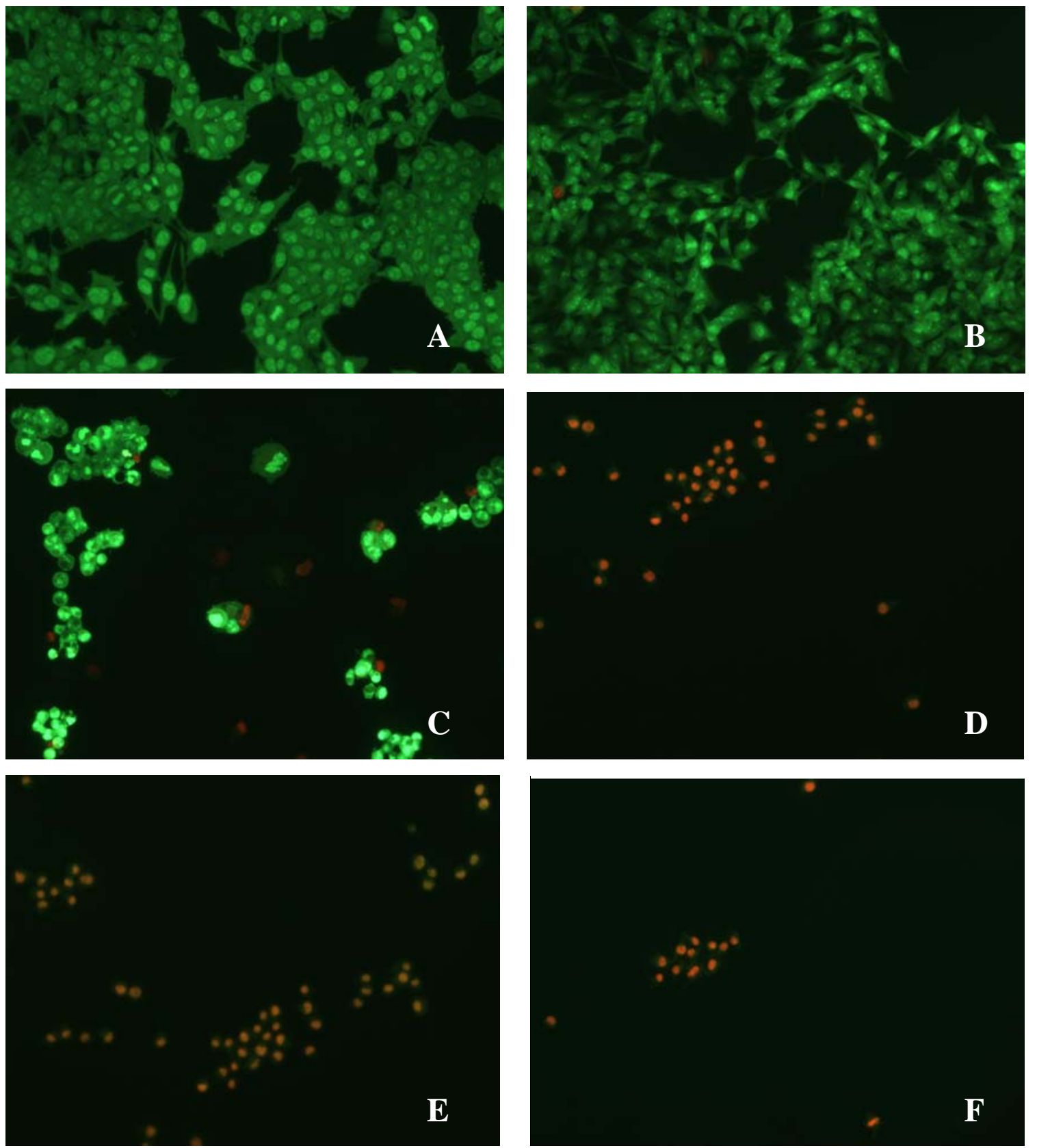

Figura 17 - Detecção de morte celular por fluorescência utilizando a técnica da laranja de acridina/brometo de etídio. As células foram expostas por 24 horas à subfração acetato de etila III de Vernonia scorpioides. (A) controle; (B) controle com 0,1\% tween; (C) tratamento de $1 \mu \mathrm{g} / \mathrm{ml}$. Observar que as células mantêm a morfologia alterada, há presença de células mortas e número reduzido de células vivas; Os tratamentos de 5 $\mu \mathrm{g} / \mathrm{ml}(\mathrm{D}), 25 \mu \mathrm{g} / \mathrm{ml}$ (E) e de $50 \mu \mathrm{g} / \mathrm{ml}(\mathrm{F})$ provocaram morte de todas as células. Objetiva de $10 x$ 
5. 5 Verificação de alterações morfológicas

As células B16F10 do grupo controle que não foram submetidas ao tratamento com a subfração acetato III de Vernonia scorpioides as células permaneciam vivas, apresentavam a carioteca e cromatina bem preservadas, núcleos bem delimitados algumas células já em processo de divisão celular, presença de pequeno corpúsculos residuais, porém insignificantes (Figura $19(A)$ e (B)).

As células B16F10 após 12 horas de exposição à subfração acetato de etila III, é possível observar um evidente efeito citotóxico nas concentrações de $5 \mu \mathrm{g} / \mathrm{ml}$ e $30 \mu \mathrm{g} / \mathrm{ml}$. Nota-se um desarranjo celular, células mortas, alterações morfológicas nas estruturas das células, a membrana plasmática já se apresenta danificada com rupturas e muitos debris celulares (Figura 19 (B) e (C)).

Com 24 horas de exposição, o padrão de resposta ao tratamento e mantém semelhante ao de 12 horas, mostrando evidente um quadro de morte celular, apresentando mais restos celulares no meio (Figura $19(E)$ e $(F)$ ). 

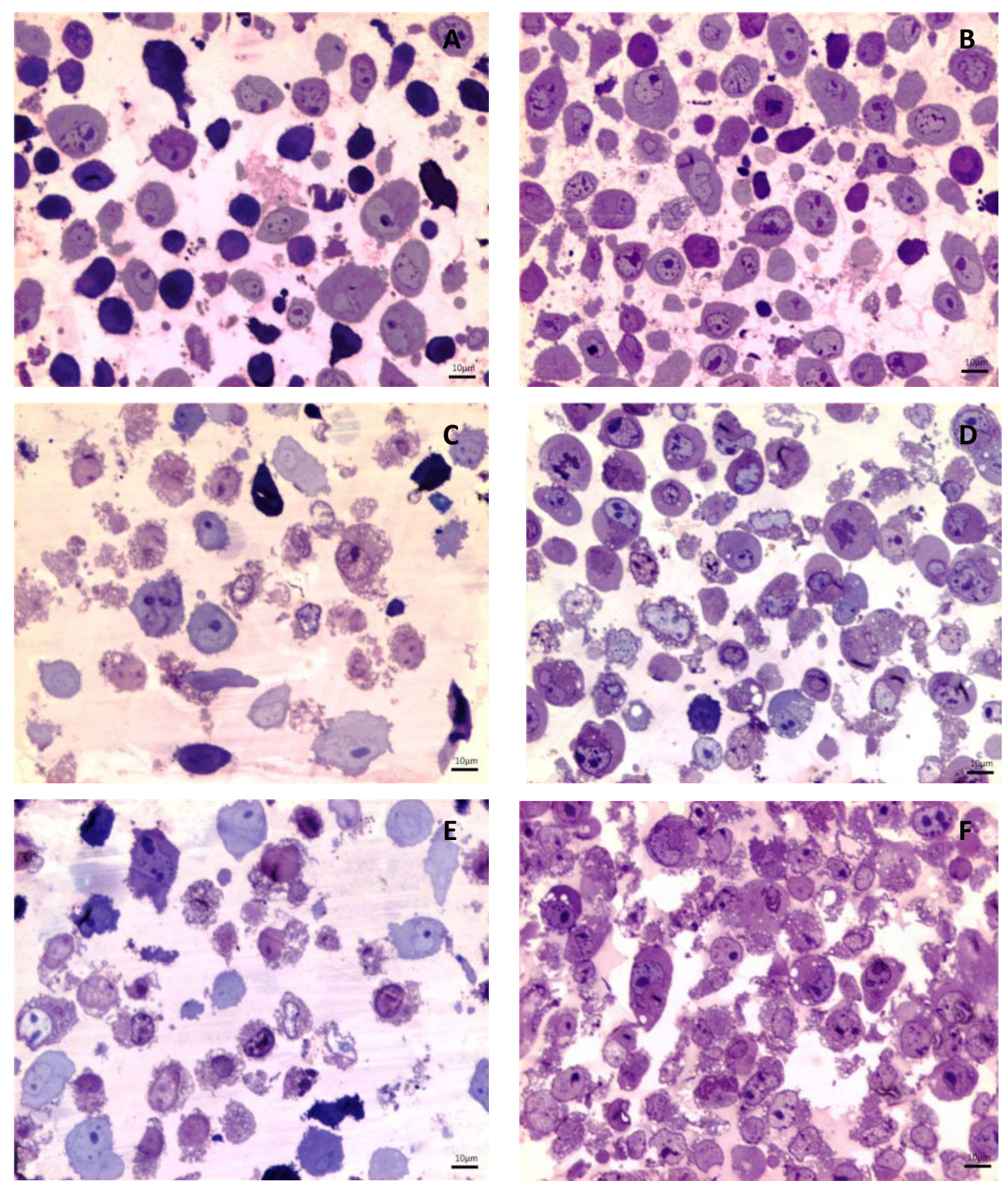

Figura 19 - Corte ultra fino do cultivo de células B16F10 in vitro com exposição à subfração acetato de etila. (A) grupo controle em exposição ao tratamento por 12 horas, (B) grupo controle em exposição ao tratamento por 24 horas, (C) tratamento de $5 \mu \mathrm{g} / \mathrm{ml}$ em exposição por 12 horas, (D) tratamento de $30 \mu \mathrm{g} / \mathrm{ml}$ em exposição por 12 horas, (E) tratamento de $5 \mu \mathrm{g} / \mathrm{ml}$ em exposição por 24 horas e (F) tratamento de $30 \mu \mathrm{g} / \mathrm{ml}$ em exposição por 24 horas. Notar que as alterações já começam a ocorrer logo nas primeiras 12 horas de tratamento. 
5. 6 Avaliação macroscópica dos camundongo

A avaliação macroscópica foi realizada em todos os grupos durante os experimentos.

\subsubsection{Tratamento 7 dias}

Grupo controle - os animais exibiam lesões cutâneas, ulcero necróticas, nodulares, por vezes confluentes, de coloração enegrecida. Eram extensas, medindo até $8 \mathrm{~cm}$ de extensão figura 19. A necropsia dos órgãos internos revelou baço de forma preservada e volume aumentado em todos os animais, em media de $25 \mathrm{~cm}$; tinham superfície vinhosa, homogênea e brilhante. Os demais órgãos exibiram número, topografia e distribuição habituais.

Animais tratados - após a inoculação das células neoplásicas, esperou-se por aproximadamente 10 dias para o inicio do tratamento, período em que a neoplasia cutânea era macroscopicamente aparente medindo em média $2 \mathrm{~cm}$ de extensão figura 20. No final do tratamento as lesões demonstraram ulceras profundas, de fundo enegrecido e bordos elevados nos locais de inoculação da subfração. Os órgãos internos revelaram o mesmo padrão do grupo controle.

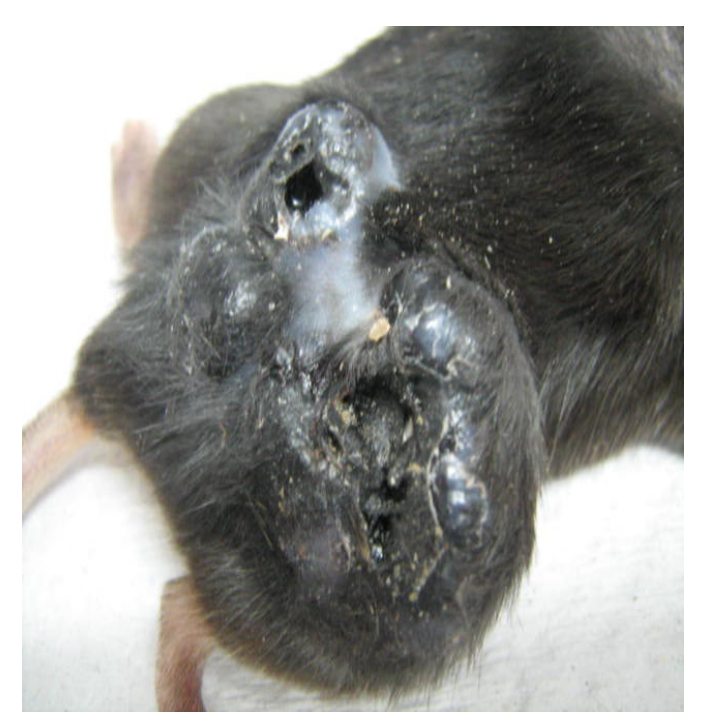

Figura 19 - Animal grupo controle

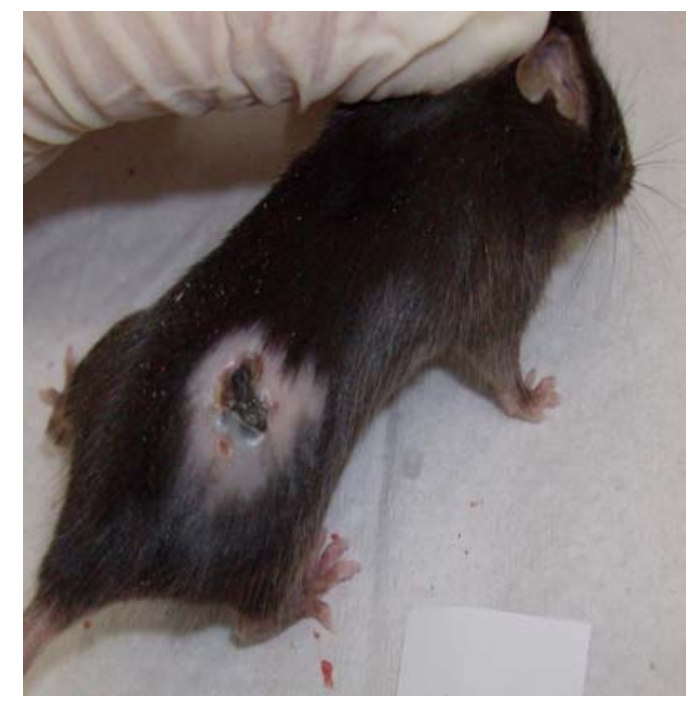

Figura 20 - Animal após 7 dias de tratamento 
5.6.2 Tratamento dias alternados e tratamento precoce

Grupo controle - os animais exibiam alterações cutâneas e nos órgãos internos de padrão semelhante ao grupo controle previamente descrito. O tamanho esplênico se correlacionava com a extensão da neoplasia cutânea.

Animais tratados em dias alternados - dois dias após a inoculação das células neoplásicas iniciou-se o tratamento em dias alternados. Os camundongos não exibiam lesões macroscópicas no inicio do tratamento. Durante o período de estudo desenvolveram pequenos nódulos sem ulceração (Figura 21).

Animais com tratamento precoce - após inoculação de células de melanoma B16F10 foi inoculado a subfração Acetato de etila III, observando-se que alguns camundongos desenvolveram pequenos nódulos cutâneos e outros não apresentaram lesões macroscópicas. O exame dos órgãos internos não apresentou alterações significativas exceto pelo baço que tinha pequeno aumento (Figura 22).

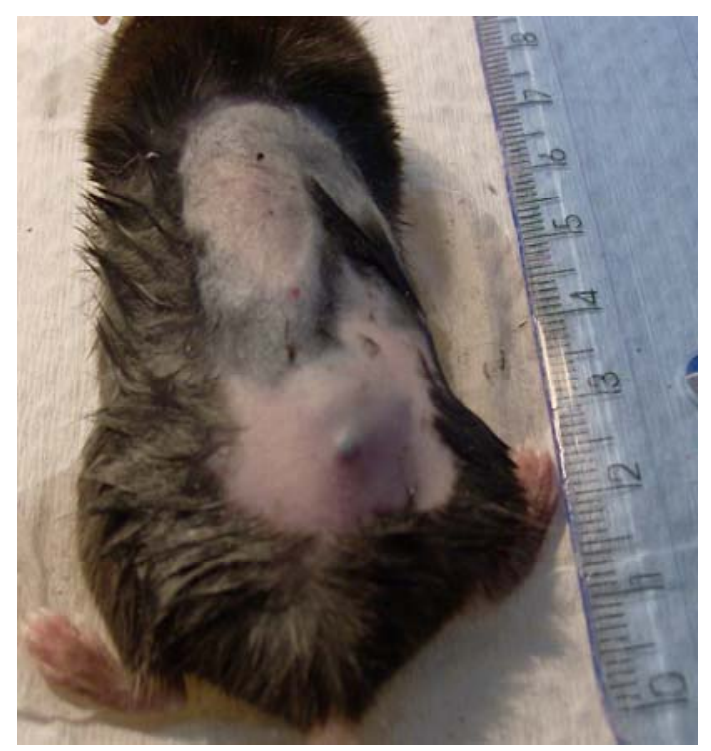

Figura 21 - Animal após tratamento dias alternados.

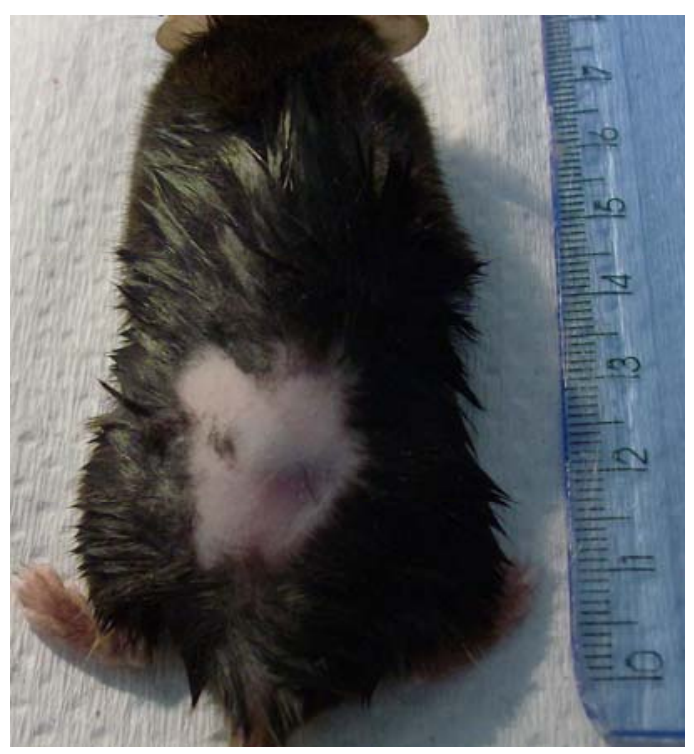

Figura 22 - Animal após tratamento precoce. 


\subsection{Avaliação microscópica dos órgãos camundongos C57BL/6}

Após os tratamentos os animais foram eutanasiados e cortes $5 \mu \mathrm{m}$ de espessura foram obtidos para confecção de lâminas, e coradas em hematoxilinaeosina para análise histopatológica.

Conforme a figura 23 se pode visualizar a diferença entre o baço dos animais normais que não foram submetidos a células tumorais e ao tratamento com a subfração acetato de etila III de Vernonia scorpioides e o baço de um animal do grupo controle com tumor.

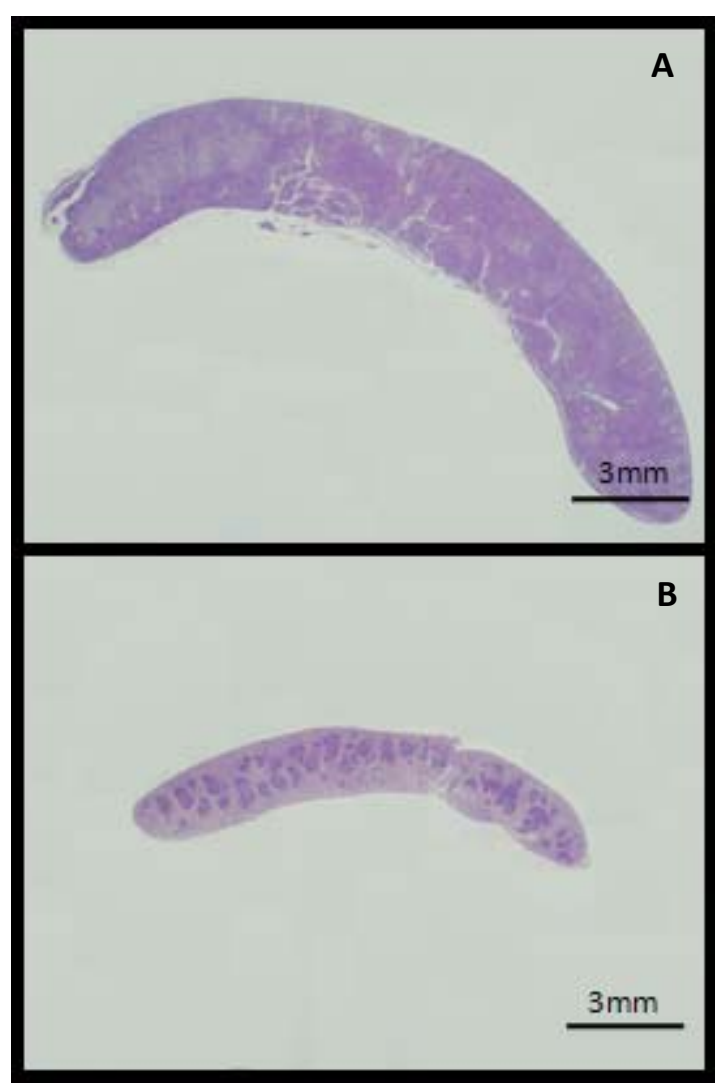

Figura 23 - Comparativo entre baço normal figura (B) baço de camundongo C57BL/6 não submetido ao estudo, obtido a partir do arquivo do biotério do Departamento de Patologia da Faculdade de Medicina Veterinária e Zootecnia da Universidade de São Paulo (FMVZ-USP), (sem tumor e sem tratamento). Forma alongada com boa delimitação entre a polpa branca e a polpa vermelha, e baço de animal do grupo controle figura (A) corte histológico do baço mostrando pobre delimitação entre a polpa vermelha e branca 


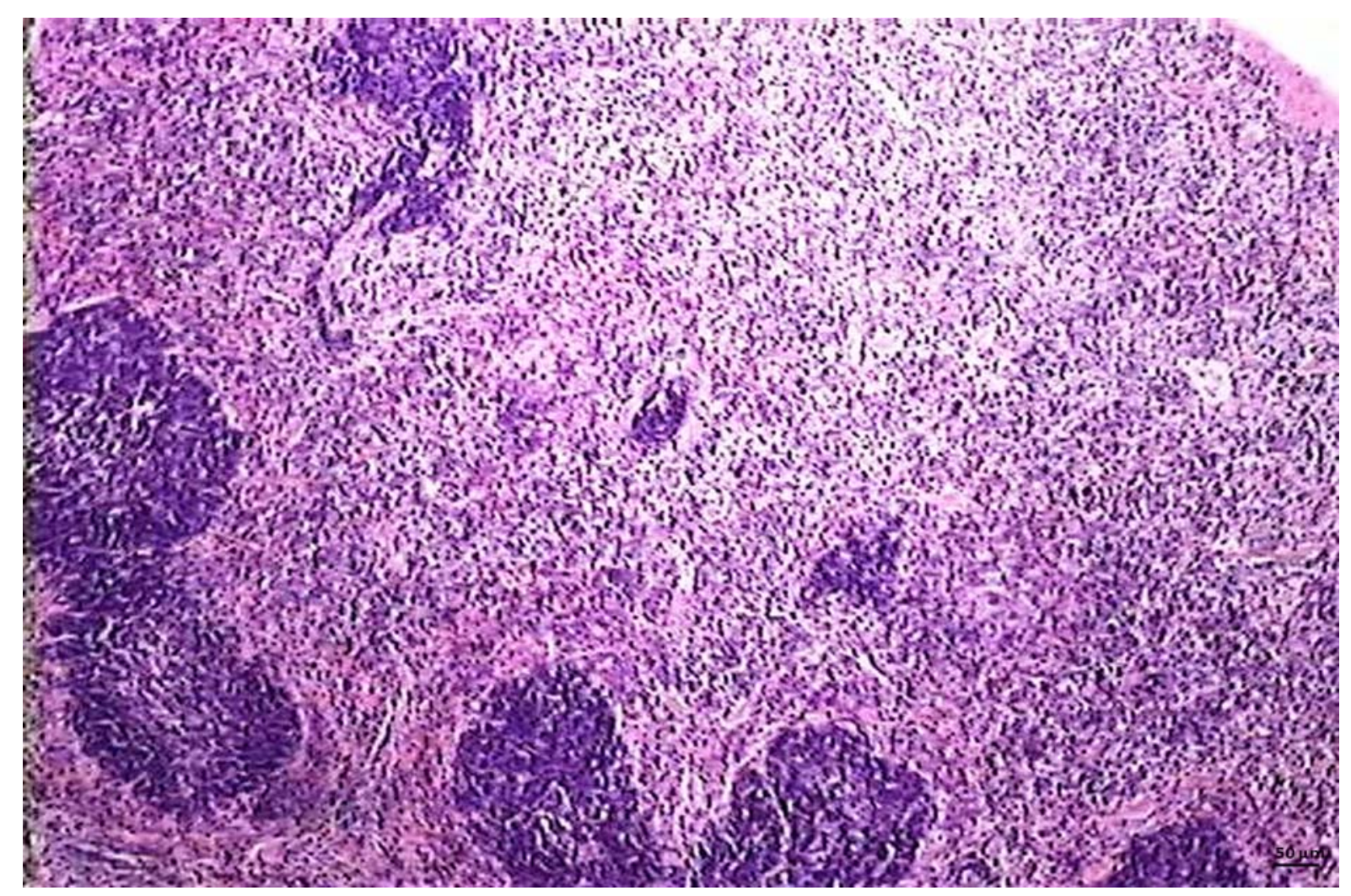

Figura 24 - Baço de camundongo C57BL/6 não submetido ao estudo, obtido a partir do arquivo do biotério do Departamento de Patologia da Faculdade de Medicina Veterinária e Zootecnia da Universidade de São Paulo (FMVZ-USP), (sem tumor e sem tratamento). No extremo direito do campo pequeno segmento de cápsula explenica. (HE, objetiva 4X) 


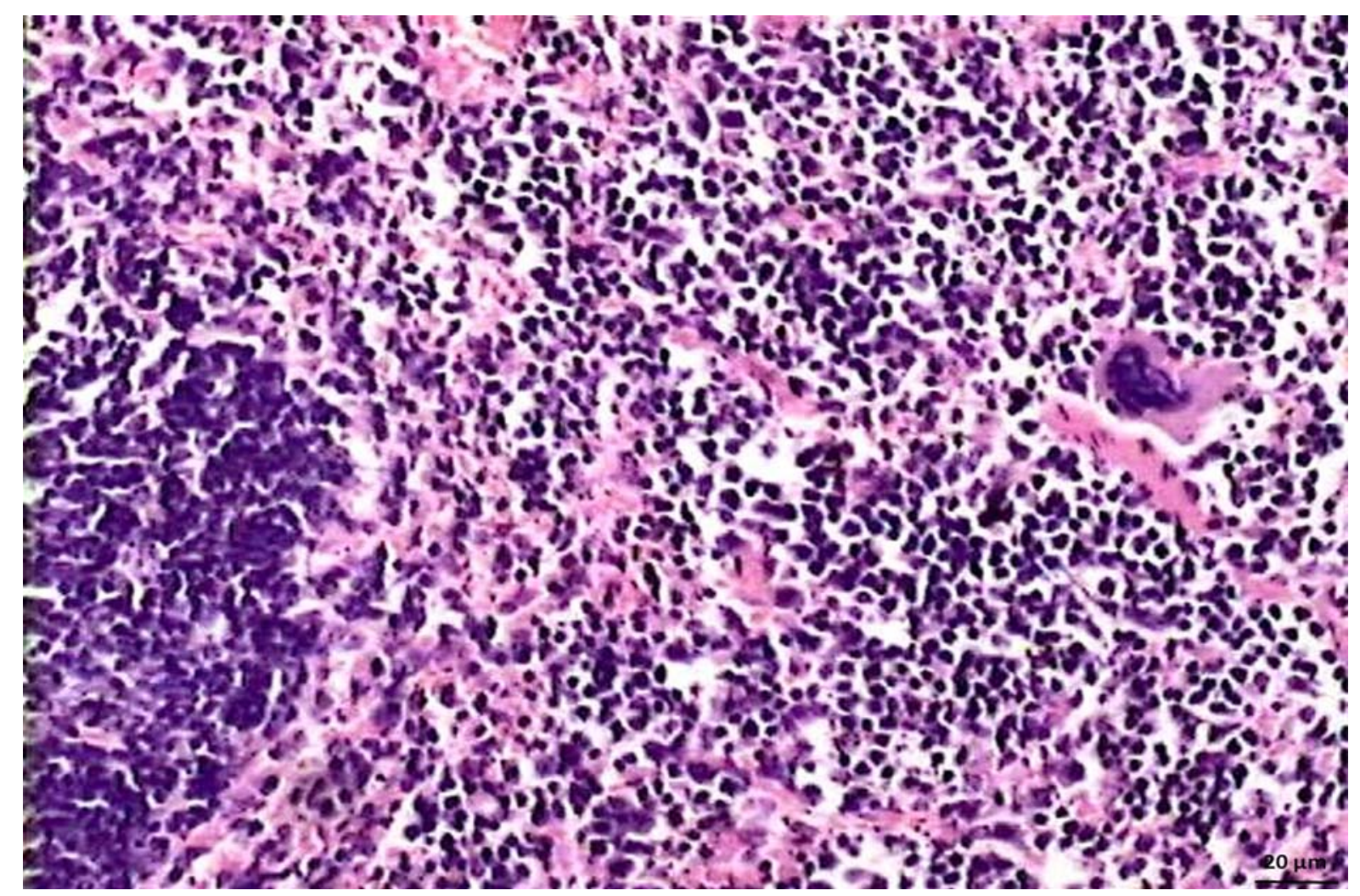

Figura 25 - Baço de camundongo C57BL/6 não submetido ao estudo, obtido a partir do arquivo do biotério do Departamento de Patologia da Faculdade de Medicina Veterinária e Zootecnia da Universidade de São Paulo (FMVZUSP), (sem tumor e sem tratamento)polpa vermelha contendo células hematopoeticas, com megacariócitos. Em proporção de 0-2/CGA (HE, objetiva 20X)

5.7.1 Tratamento sete dias

Grupo controle - cortes histológicos realizados nas lesões tumorais cutâneas evidenciaram extensa neoplasia nodular, sólida, com focos de necrose e hemorragia. A superfície cutânea exibiu necrose epidérmica com ulceração recobertas por crosta fibrino-neutrofílica-necrótica com evicencias de açao bacteriana. As células neoplásicas são pouco coesas, poligonais, volumosas com núcleos arredondados e centrais e nucléolos eosinofílicos conspícuos. Os citoplasmas são eosinofílicos com moderada a intensa pigmentação melânica. Presença de numerosas figuras de mitose, típicas e atípicas. Taxa mitóticas: 4/CGA.(campo de grande aumento), (figura 28). Não se observa infiltrado inflamatório. 
Baço - tamanho aumentado (figura 23 A), constituído por palpa branca pouco evidente e acentuada expansão da polpa vermelha (Figura 26) com infiltração difusa dos sinusóides por células de linhagem linfóide maduras e imaturas ao lado de numerosos megacariócitos figura 27 (Média de 7/CGA), quando comparado ao baço normal figuras 24 e 25. Não se evidenciaram células neoplásicas. Os baços tiveram aumento volumétrico proporcional ao volume da tumoração cutânea.

Os demais órgãos examinados não mostraram alterações microscópicas e estavam livres de infiltração neoplásicas

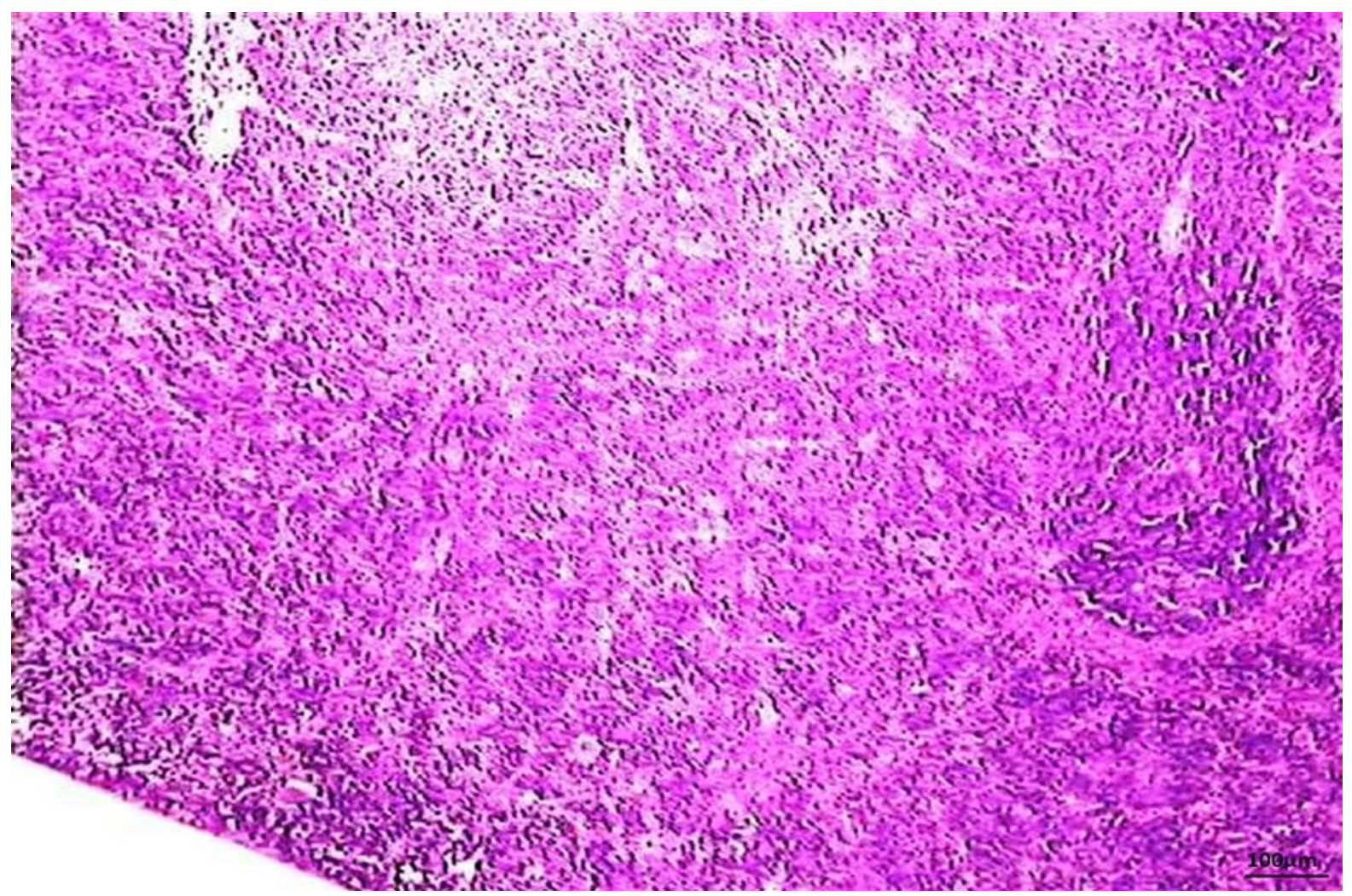

Figura 26 - Grupo controle, corte histológico do baço mostrando pequeno nódulo da polpa branca com artéria centro folicular e acentuada expansão da polpa vermelha devido a presença de numerosas células linfóides (HE, objetiva 4X). 


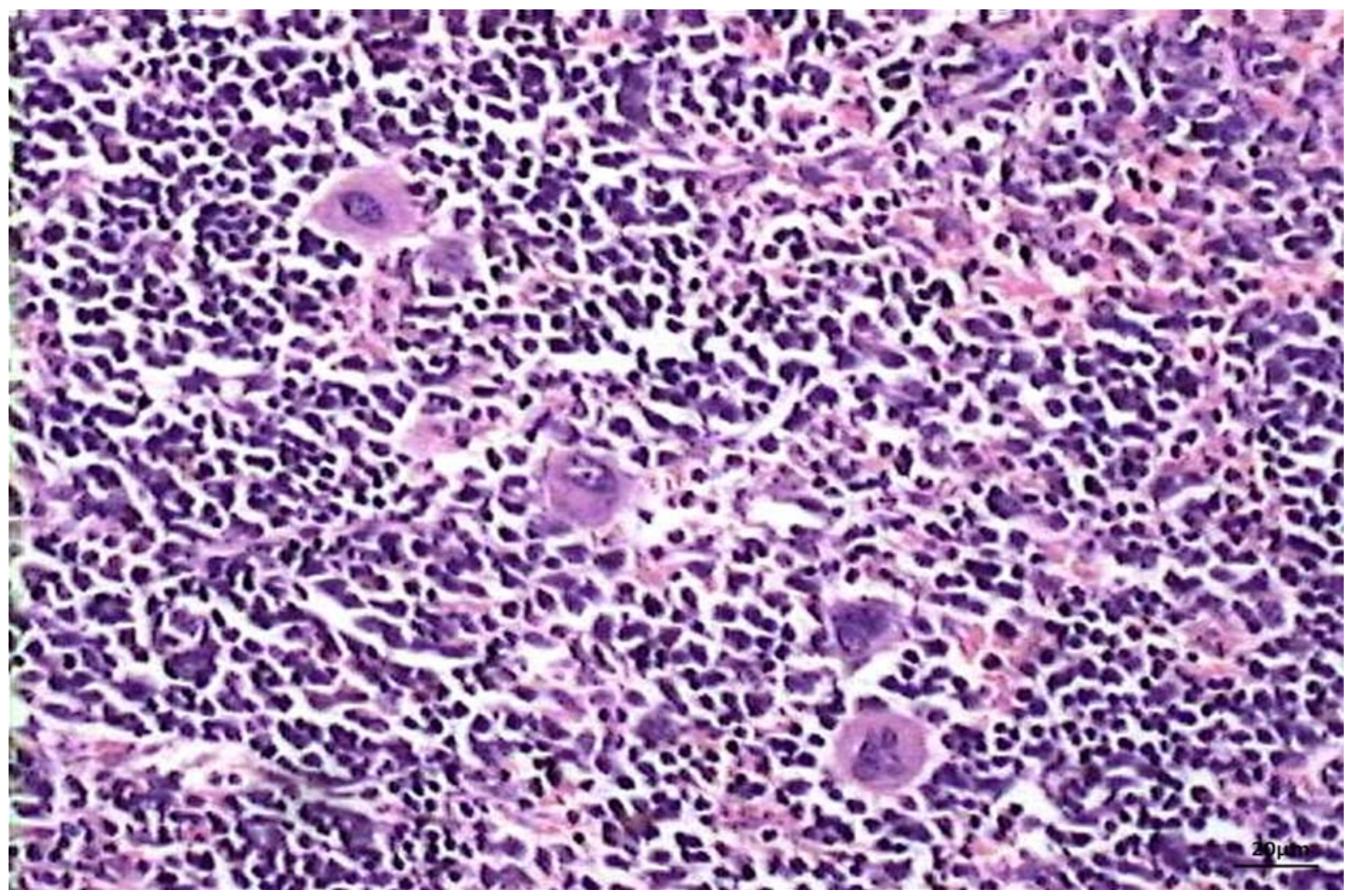

Figura 27 - Grupo controle, baço mostrando numerosos megacariócitos em proporção de 5-7/CGA (HE, 20X)

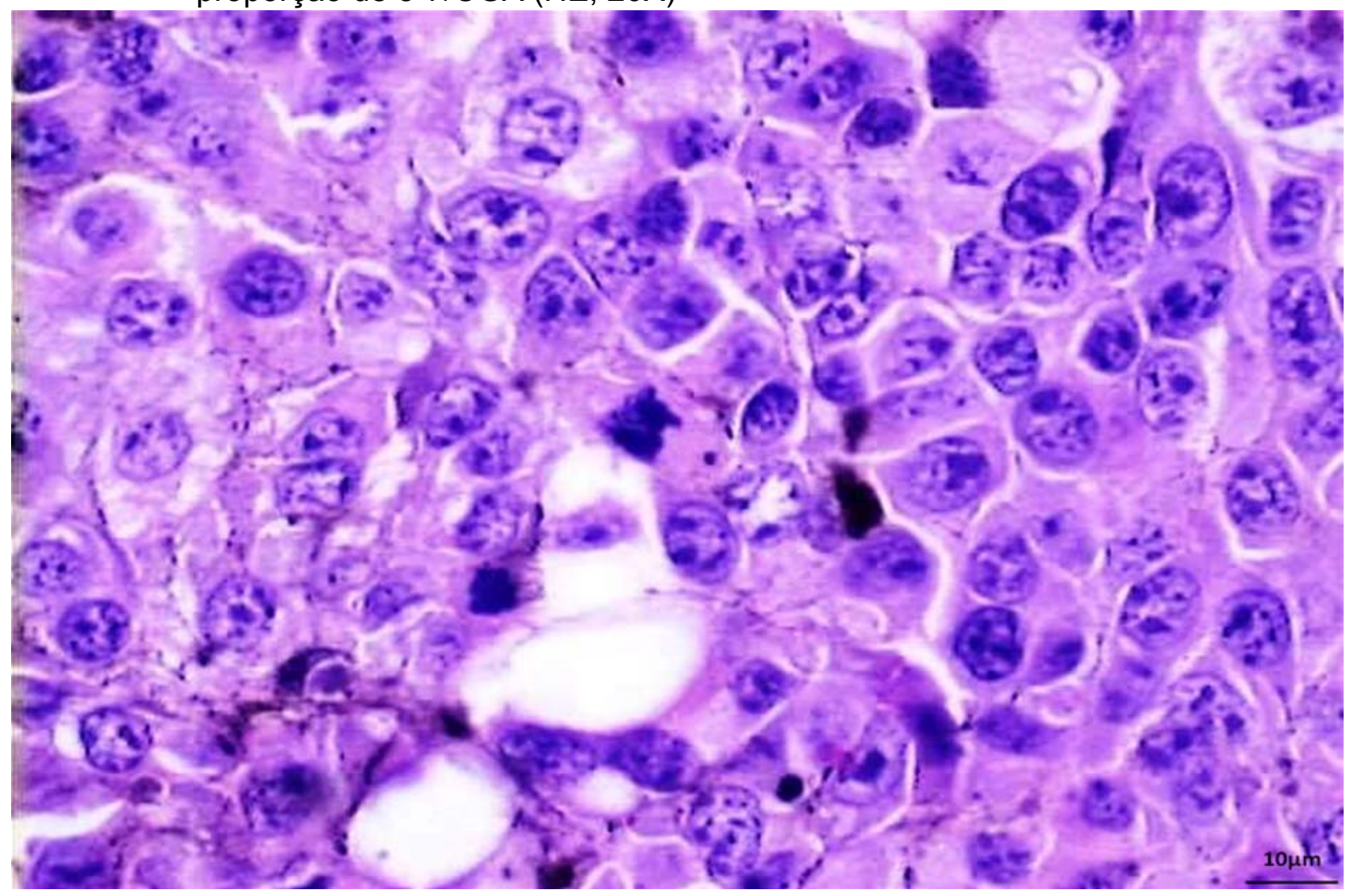

Figura 28 - Grupo controle, neoplasia constituída por células pouco coesas, poligonais volumosas com nucléolos evidentes, figuras de mitose e pigmento castanho citoplasmático. (HE, 40X). 
Animais tratados - as neoplasias cutâneas continuaram viáveis com nódulos sólidos de células neoplásicas. Associaram-se extensas áreas de necrose tumoral extensa (figura 29), e em alguns casos, exsudato neutrofilico com formação de microabscessos. Um dos camundongos, cujo crescimento tumoral foi menor, exibiu em um corte histológico, necrose total das células neoplásicas. Foram substituídas por material amorfo eosinofilico com grande quantidade de pigmento melânico figura 30.

Fígado amplamente amostrado em todos os animais demonstrou a arquitetura histológica preservada, sendo constituído por hepatócitos sem sinais de esteatose ou de injuria tóxica, figura 32.

Rim constituído por glomérulos e túbulos preservados e sem sinais de toxicidade, figura 31.

Baço manteve o mesmo padrão lesional descrito nos animais do grupo controle.

Demais órgãos sem alterações significativas.

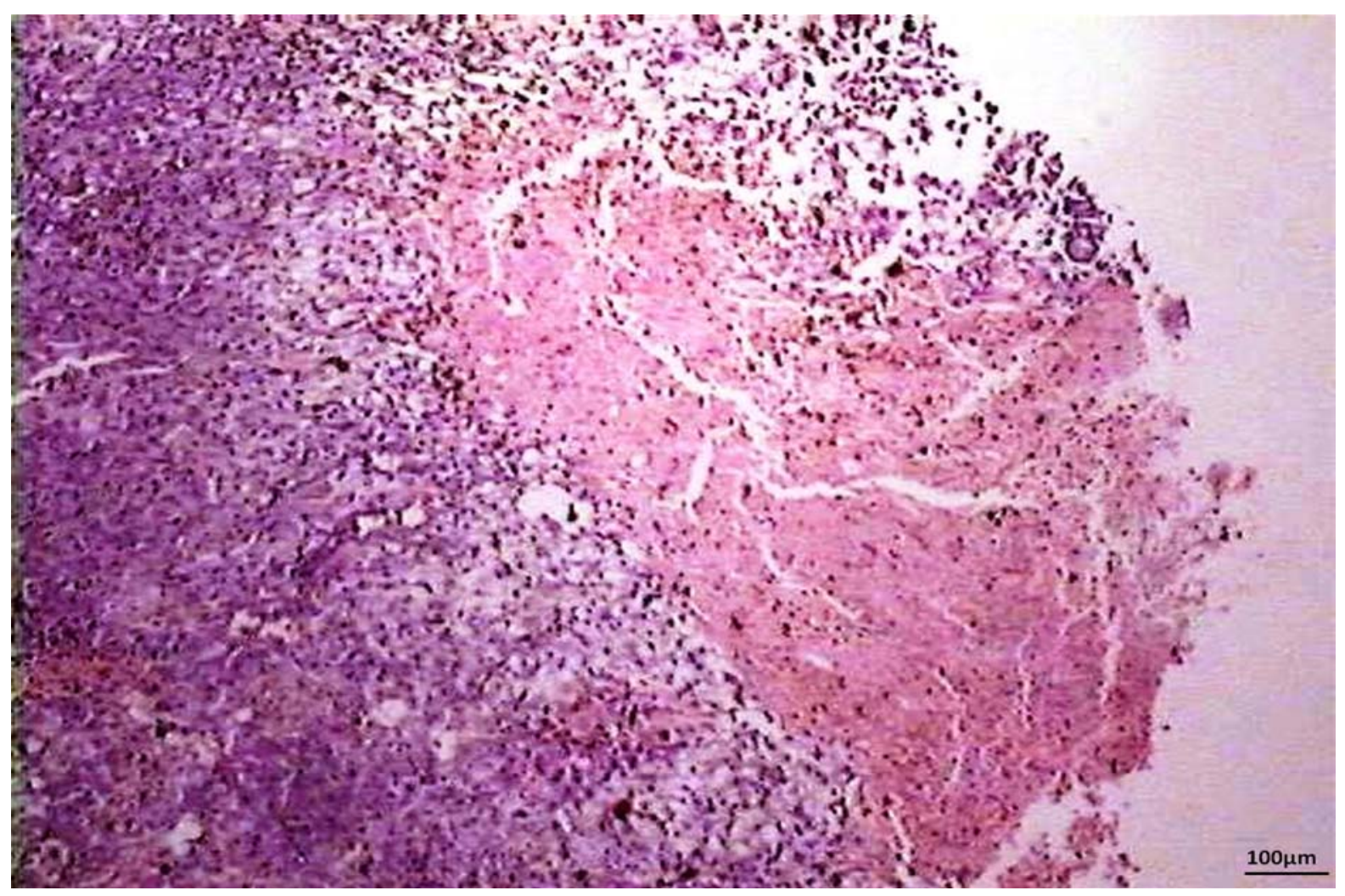

Figura 29 - Tratamento 7 dias, corte histológico realizados na neoplasia cutânea evidenciam extensas áreas de necrose ( $\mathrm{HE}$, objetiva $4 \mathrm{X})$ 


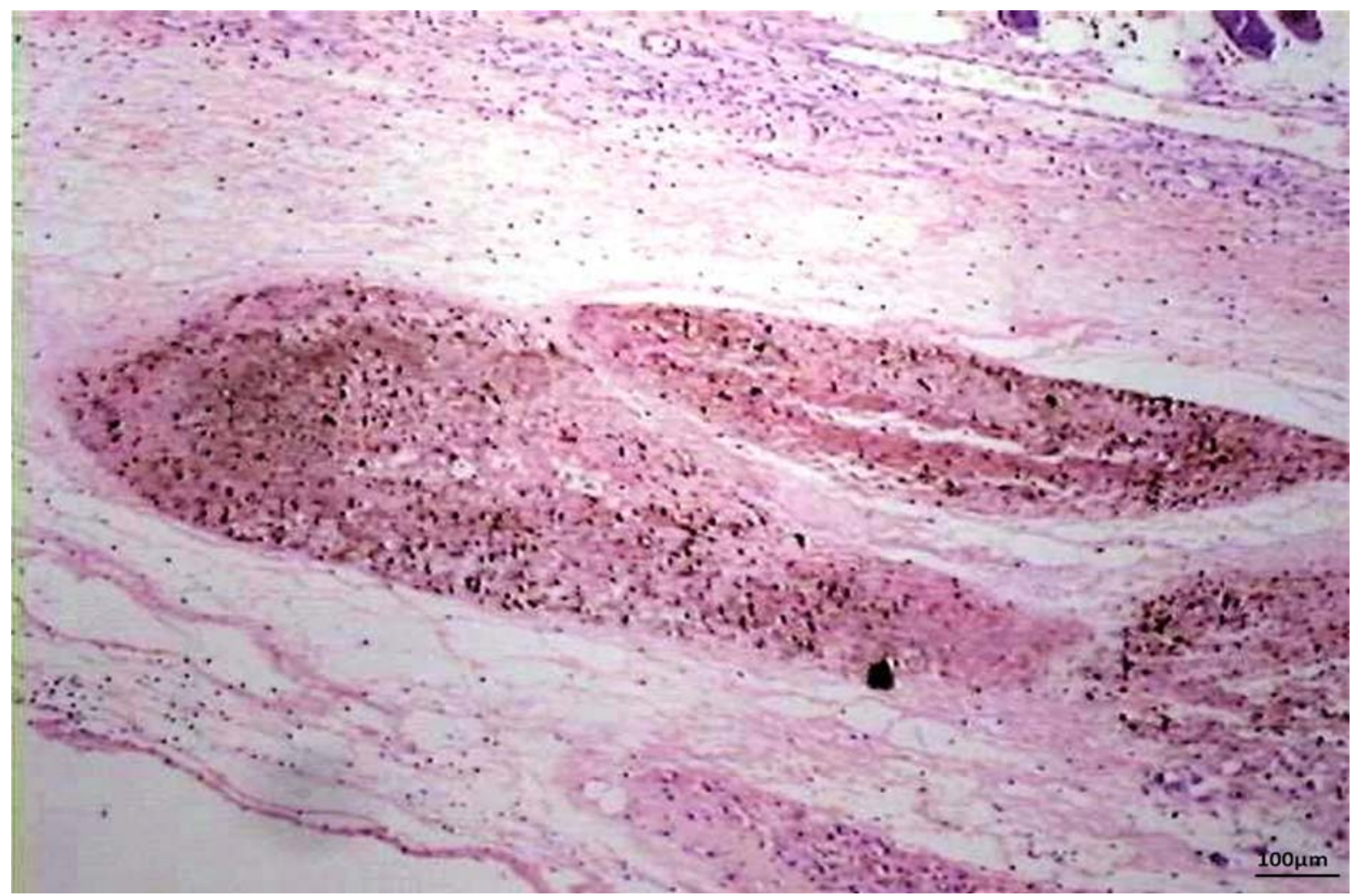

Figura 30 - Tratamento 7 dias, corte de pele mostrando remanescente de neoplasia extensamente necrótica com pigmento melânico (HE, objetiva 4X)

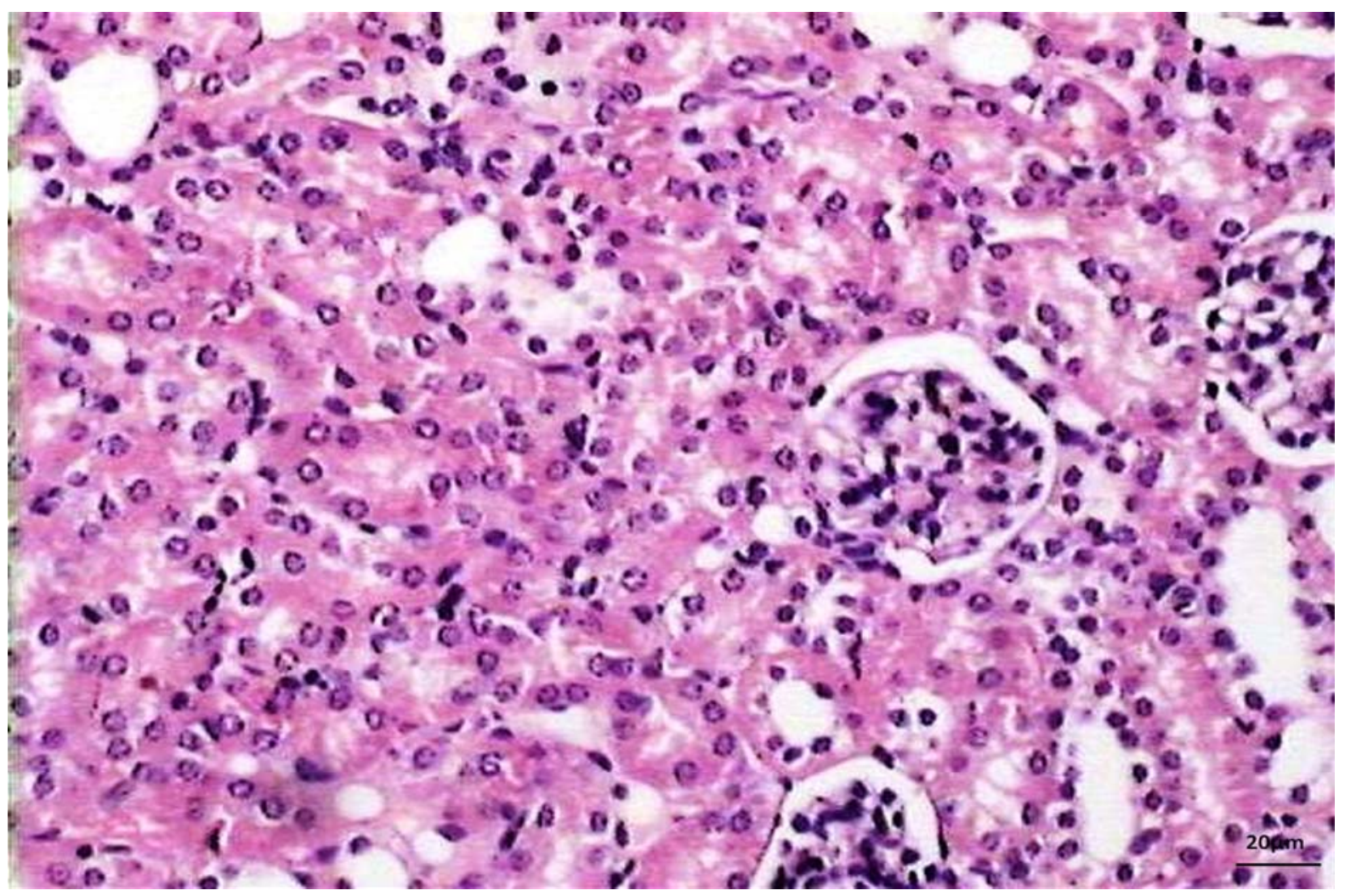

Figura 31 - Tratamento 7 dias, rim, corte histológico de rim mostrando glomérulos e túbolos sem alteração (HE, objetiva 20X) 


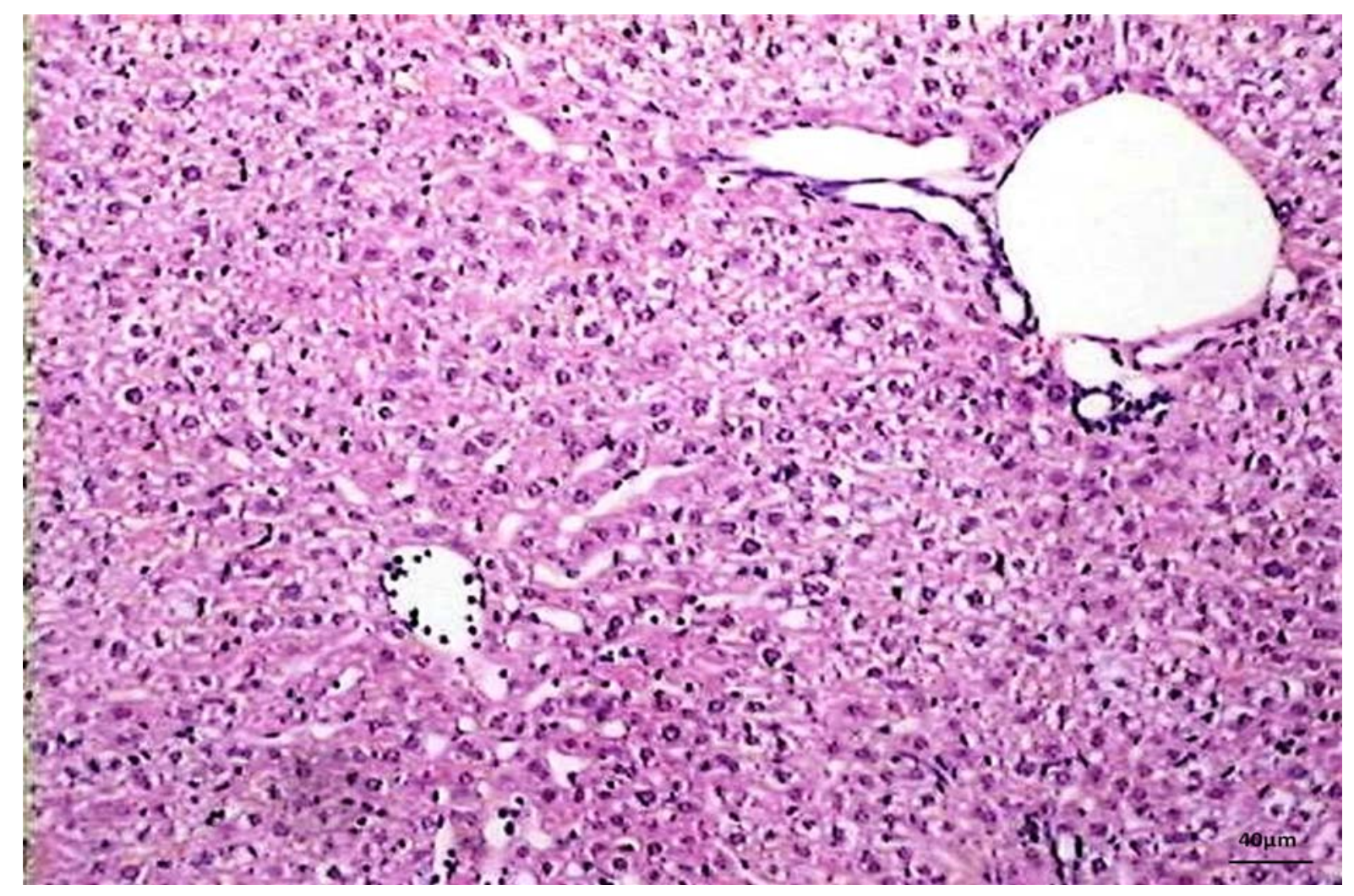

Figura 32 - Tratamento 7 dias, corte histológico de fígado evidencia veia centro lobular, trabéculas de hepatócitos permeadas por sinusóides e espaço porta contendo a tríade portal mostrando estrutura histológica preservada (HE, objetiva 10x)

\subsubsection{Tratamento dias alternados e tratamento precoce}

Grupo controle - as lesões cutâneas e nos órgão internos tem padrão semelhante ao grupo controle previamente descrito. A lesão microscópica esplênica foi mais intensa nos casos em que houve maior crescimento tumoral cutâneo.

Tratamento dias alternados - todos os camundongos exibiam neoplasia cutânea viável que formava pequenos nódulos ao lado de necrose de padrão focal ou geográfica.

Os baços apresentavam alargamento da polpa branca com infiltração linfóide da polpa vermelha de leve a moderada intensidade conforme visto na figura 33.

Os demais órgãos não exibiram alterações significativas. 
Tratamento precoce - as alterações foram semelhante ás descritas para o tratamento em dias alternados. Nenhum dos animais exibia neoplasia com ulceração e necrose epidérmica.

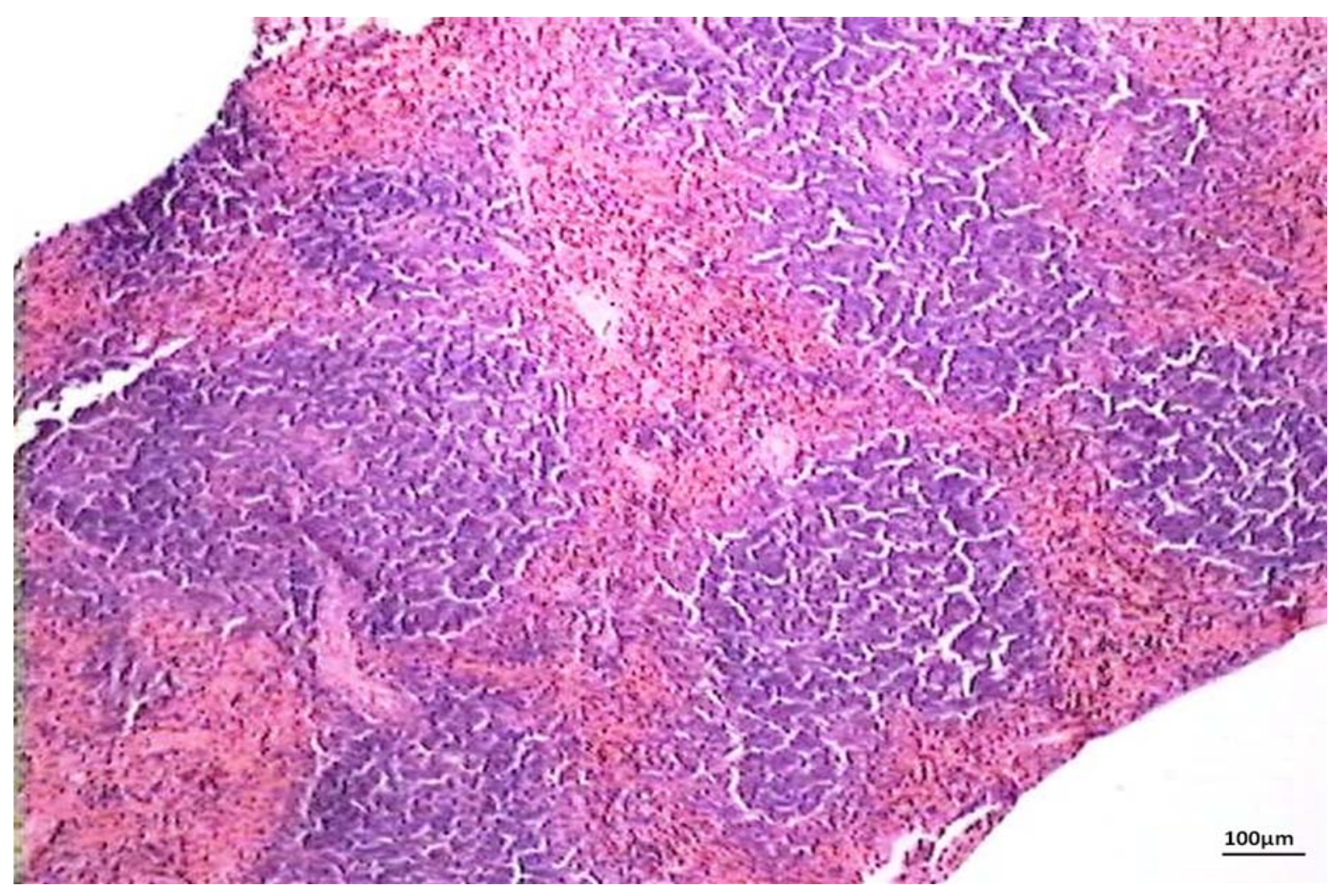

Figura 33 - Tratamento dias alternados, corte histológico de baço mostrando lesão em fase inicial com infiltração da polpa vermelha por células linfóides (HE, objetiva de $4 \mathrm{X})$ 


\subsubsection{Volume tumoral}

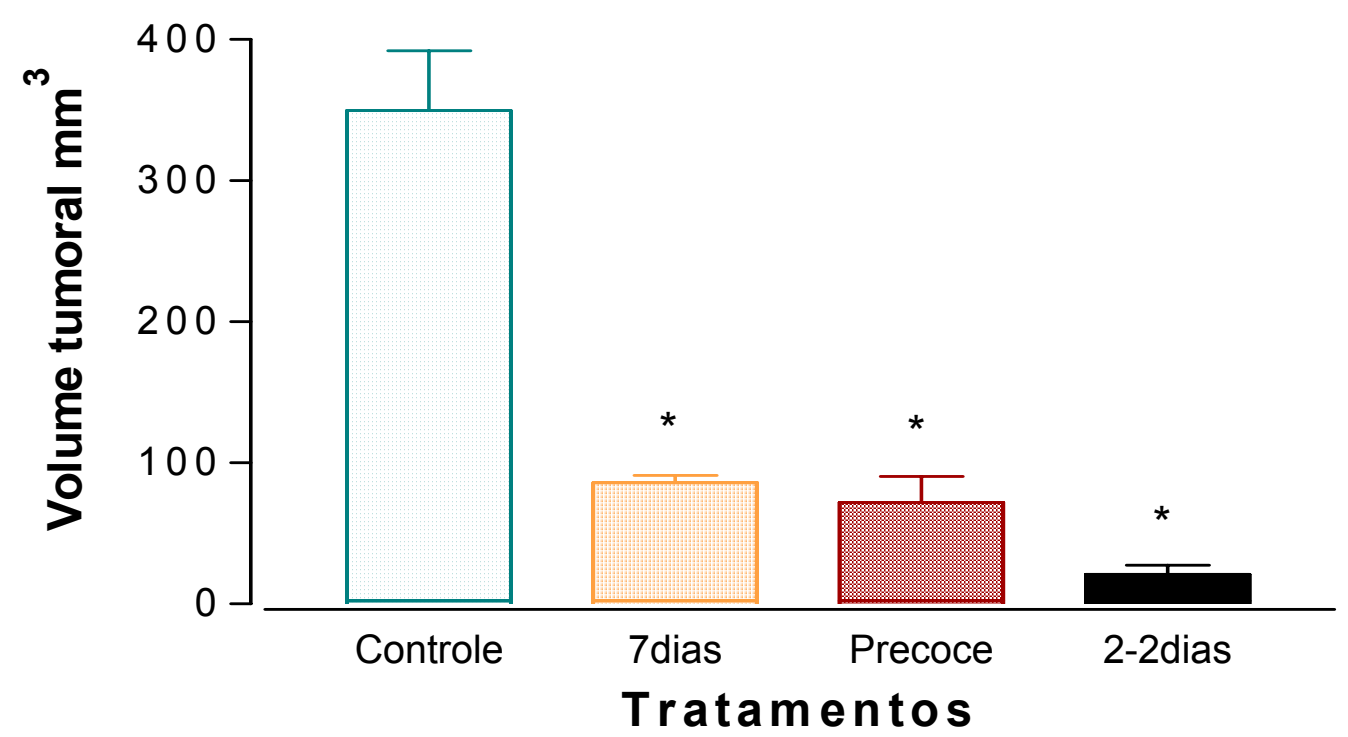

Figura 34 - Gráfico do volume tumoral em camundongos C57BL6 inoculados com melanoma B16F10 após diferentes tratamentos com $5 \mathrm{mg} / \mathrm{kg}$ da subfração acetato de etila III de Vernonia scorpioides. Teste estatístico ANOVA $(p<0,0001)$ e pós-teste Dunnett. ${ }^{*} p<0,01$ representa o nível de significância em relação ao controle

Ao término de realizado todos os experimentos in vivo um estudo comparativo entre os tratamentos foi analisado conforme figura 34, onde se observa que o grupo controle apresentou o volume tumoral superior a todos os tratamentos, quando os animais receberam tratamento de 7 dias e precoce o resultado dos volumes tumorais foi semelhante. Quando os animais receberam tratamento a cada dois dias logo após 48 horas da inoculação das células tumorais o volume final do tumor reduziu significantemente em relação aos outros grupos principalmente ao grupo controle, mostrando-se ser o tratamento mais eficaz. 


\section{DISCUSSÃO}

Melanoma é um dos tumores mais agressivos e que freqüentemente apresenta quimioresistência às drogas comumente utilizadas. Muitos agentes quimioterápicos têm como mecanismos de ação bloquear o ciclo celular, não causando a morte celular por apoptose. A procura por novos tratamentos quimioterápicos para esse tumor tem sido de grande importância (ROZENBLAT et al., 2008).

Nos tumores, a resistência às drogas é principalmente atribuída para o improvável reparo do DNA, provocando defeitos nos processos apoptóticos (ROZENBLAT et al., 2008).

O estudo com plantas medicinais cada vez mais esta mostrando grandes descobertas de novos fármacos. Os produtos naturais são de extrema importância para a busca de novos agentes quimioterápicos. Na oncologia existem vários quimioterápicos oriundos de plantas, porém o trabalho com plantas é muito complexo devido à grande variedade de constituintes químicos (CHANG, 2000).

A planta do gênero Vernonia vem sendo estudada por vários pesquisadores, possuindo mais de 1000 espécies. Estima-se que 20\% dessas espécies encontramse no Brasil (LOPES, 1991).

O gênero Vernonia pertence às Asteraceae (Compositae), família de plantas que produzem um composto característico, as lactonas sesquiterpênicas, com diversas atividades biológicas já documentadas (PICMAN, 1986; KRISHNA-KUMARI et al., 2003). Diferentes espécies de Vernonia são relatadas na literatura por possuírem diversos efeitos biológicos: a infusão de folhas de $V$. canescens é usada para impedir hemorragia e diminuir a inflamação; $V$. deppeana é administrada oralmente para diminuir dor estomacal; $V$. leiocarpa é usada contra a asma; $V$. patens é utilizada como vermífugo (LANS et al., 2001) e V. cinerea como antibacteriano (GUPTA et al., 1993). Estas propriedades antifúngicas, antibacterianas, citotóxicas e antitumorais são atribuídas à presença das lactonas sesquiterpênicas (KUMARI, 2003).

As drogas anticâncer existentes comercialmente apresentam limitações terapêuticas. Muitos pesquisadores têm direcionado seus estudos para a geração de um único composto com características biológicas diferentes da atividade antiproliferativa da maioria dos quimioterápicos utilizados atualmente. Apesar de muitas dessas drogas estudadas serem efetivas no tratamento de cânceres em 
humanos, estudos em torno do entendimento de seus mecanismos terapêuticos e citotóxicos tem sido extensivamente realizados, na busca de modificações farmacológicas que permitam que certas drogas ofereçam maior proteção contra a toxicidade dos tecidos normais sem comprometer a atividade antitumoral do medicamento (INDAP; AMBAYE, 1991).

O extrato bruto alcoólico da planta Vernonia scorpioides é aplicado sobre úlceras de membros inferiores em idosos no Centro de Idosos de Itajaí. Sua ação em lesões da derme foi estudada experimentalmente em cobaias (LEITE et al., 2002), mostrando que na fase de cicatrização, as lesões tratadas com o extrato eram mais fibrosadas. Juntamente foi mostrado um efeito citotóxico deste extrato na fase aguda de lesões cutâneas provocadas em camundongos (DALAZEN et al., 2005).

Atualmente já se sabe que as subfrações de Vernonia scorpioides e outras plantas da família Asteraceae contêm lactonas sesquiterpênicas. Muitos são os estudos comprovando a atividade antitumoral destas moléculas, tanto in vitro com in vivo (KHALIL et al., 2005; SWEENEY et al., 2005; BUSKUHL, 2007).

O mecanismo de ação antitumoral mais atual das lactonas sesquiterpênicas é a inibição do Fator Nuclear kappa B (NF-kappa B), responsável pela ativação de diversos genes, inclusive os genes responsáveis pela multiplicação celular e pela apoptose (MULLER et al., 2004). Algumas lactonas sesquiterpênicas contém uma estrutura funcional em comum ( $\alpha-m e t i l e n o-\gamma$ lactona) que é a responsável por interferir na via de sinalização do NF-kappaB e nas proteínas MAPK (Proteínas Kinases Mitogênicas Ativadas) indutoras de mitose (ZHANG et al., 2005). Lactonas sesquiterpênicas modificadas em laboratório têm sido testadas in vitro contra uma série de células tumorais, sendo que algumas apresentam atividade antitumoral e outras não (QUINTERO et al., 1999).

Vários trabalhos encontrados na literatura referentes ao gênero Vernonia (Asteraceae) mostraram as atividades referentes a esse gênero de plantas (DALAZEN et al., 2005).

Lactonas sesquiterpênicas foram isoladas de Inula viscosa (Compositae) e sua atividade citotóxica foi demonstrada, inibindo a fase do ciclo celular em $G_{2} / M$ causando morte celular por apoptose, lactonas sesquiterpênicas podem estar representando um potente agente quimioterapêutico contra neoplasias que apresentam quimioresistências às drogas existentes (ROSENBLAT et al., 2008). 
Alguns relatos demonstram a citotoxicidade das lactonas sesquiterpênicas. Chem et al., (2007) verificaram a citotoxicidade de lactonas em células tumorais HT29 com $60 \%$ de diminuição das células, A2058 e HepG2 com quase 100\% de diminuição das células.

Estudos mostram que vários tipos de lactonas sesquiterpênicas apresentaram resultados extremamente citotóxicos para os tipos celulares Hela, Jukart T e PBMCs (HILMI et al., 2003). Lactonas de Inua helenium foram isoladas e demonstraram possuir ação citotóxica para os tipos celulares Hela, B16F10 e MK-1(KONISHI et al., 2002).

Recentemente, um estudo isolou lactonas sesquiterpênicas de Calea Urticifolia, conhecida por possuir quantidade abundante em lactonas sesquiterpênicas. Este estudo mostrou os efeitos inibitórios dessas lactonas no melanoma em camundongos C57B16, induzindo as células neoplásicas a apoptose $(\mathrm{OHGUCHI}$ et al., 2009). Pesquisadores observaram interessantes atividades biológicas de lactonas sesquiterpênicas em algumas linhagens de células tumorais, dentre elas a indução de apoptose (UMEMURA et al., 2008).

A subfração acetato de etila III de Vernonia scorpioides foi escolhida para ser estudada neste trabalho devido a sua alta atividade contra o tumor ascítico de Erlich, avaliada em estudos prévios com camundongos Swiss. No processo de partição do extrato bruto de Vernonia scorpioides até a chegada à subfração acetato de etila III, todas as frações intermediárias foram testadas em tumor ascítico de Erlich por um período de sete dias de tratamento. Ao final deste período, após lavagem do peritônio foi feita a contagem de células. As frações que produziam remissão total do tumor ascítico eram submetidas à nova partição, a fim de se obter frações cada vez mais purificadas. Na fase III, a subfração que produziu morte celular total de células tumorais ascíticas foi a acetato de etila III. Por esta razão partimos para um estudo mais aprofundado focando em sua ação antitumoral, agora com células de melanoma murino B16F10.

Do extrato de Vernonia scorpioides que originou a subfração acetato de etila III foi feita a partição de várias subfrações até purificação de lactonas sesquiterpênicas que serão estudadas posteriormente. Porém algumas lactonas dessa partição do extrato já foram estudadas: a lactona sesquiterpênica do tipo hirsutinolídeo e glaucolides foram isoladas a partir da subfração etanol I de Vernonia scorpioides e testada nas linhagens celulares L929, B16F10 e Hela, mostrando uma citotoxicidade 
direta sobre essas células. O hirsutinolídeo teve a necrose como principal mecanismo de morte celular para as células B16F10, L929, assim como para as células Hela, apesar de ser observado apoptose em pequeno número de células (BUSKUHL, 2007).

As ações quimiopreventivas e terapêuticas da subfração acetato de etila III da planta Vernonia scorpioides foram avaliadas neste estudo em dois modelos experimentais. Primeiramente foi avaliado seu efeito sobre células de melanoma murino B16F10 em cultura submetidas à exposição de várias concentrações da subfração acetato de etila III por períodos de 24, 48, 72 e 96 horas. Posteriormente, utilizou-se o modelo in vivo para tratamento intratumoral em camundongos C57BL/6 portadores de melanoma. Foram realizados três tipos de tratamento intratumoral.

Para realizar os experimentos in vitro e in vivo, usou-se como solvente para o processo de solubilização da subfração acetato de etila III solução salina $0,9 \%$ acrescida de tween $80(0,1 \%)$. A subfração acetato de etila III é constituída de compostos vegetais que possuem característica gordurosa. O tween 80 mostrou boa eficácia em solubilizar a subfração sem comprometimento da viabilidade celular, comprovado nos grupos controle tratados com salina e tween 80 a $0,1 \%$. As células do grupo controle com tween permaneceram viáveis, com crescimento característico da linhagem, apresentando morfologia fibroblastóide típica desta linhagem celular, bem aderidas ao substrato, coesas formando um tapete de células (Figuras 6 (A), 8 (A), $10(A), 12(A))$.

Os ensaios de citotoxicidade mostraram um efeito do tipo dose-resposta, podendo se observar que a inibição de crescimento se inicia com $1 \mu \mathrm{g} / \mathrm{ml}$.

O tratamento com $1 \mu \mathrm{g} / \mathrm{ml}$ nos tempos testados mostra redução de crescimento em relação ao controle estatisticamente significativo. Pode-se observar menor densidade celular, porém as células mantêm o crescimento. As células tratadas com esta concentração não demonstram grandes alterações em sua morfologia, como pôde ser observado pelas imagens (Figuras 6(B), 8(B), 10(B) e 12(B)). Porém entre 72 horas e 96 horas ocorre um aumento do numero de células, as células que permaneceram vivas começam a multiplicar-se (Figura 13), o que pode estar relacionado à perda da ação citotóxica da subfração acetato de etila III de Vernonia scorpioides.

As concentrações de $5 \mu \mathrm{g}, 7 \mu \mathrm{g}, 10 \mu \mathrm{g}, 25 \mu \mathrm{g}, 50 \mu \mathrm{g}, 70 \mu \mathrm{g}$ e $100 \mu \mathrm{g}$ mostraram elevada toxicidade nos diferentes tempos de tratamento. Nestas concentrações 
houve morte de praticamente todas as células. As imagens mostram células arredondadas, com perda da vitalidade e elevada quantidade de debris celulares (Figuras $6(C),(D),(E),(F),(G)$ e $(H), 8(C),(D),(E),(F),(G)$ e $(H), 10(C),(D),(E)$ e $(F)$ e $12(C),(D),(E),(F),(G),(H)$ e $(I))$.

A coloração por brometo de etídio e laranja de acridina possibilita identificar em vermelho (brometo de etídio) as células mortas necróticas ou em apoptose tardia penetrando naquelas células em que o mecanismo de controle da permeabilidade celular está comprometido. As células apoptóticas apresentam os sinais característicos apoptose, condensação e marginalização da cromatina nuclear, fragmentação do DNA, vacuolização citoplasmática e lise celular. Em verde (laranja de acridina) as células vivas apresentam o núcleo amarelo-esverdeado, podendo ainda identificar a presença de figuras de apoptose pela análise morfológica do núcleo celular e coloração que as células adquirem (SPECTOR, 1998; BORTNER; CIDLOWSKI, 2002).

Com o decorrer do tempo de exposição das células ao extrato observa-se o efeito tóxico da subfração frente às células B16F10. A concentração de $1 \mu \mathrm{g} / \mathrm{ml}$ demonstra uma possível interferência no crescimento celular, com o passar das horas células mortas eram visualizadas, os aspectos morfológicos estavam diferentes às células do controle, as que permaneceram vivas não apresentavam a membrana esticada, estavam arredondadas, as mortas mostraram-se adjacentes umas as outras, formando blocos de célula, mostrando uma sensibilidade maior das células ao tratamento. As concentrações de $5 \mu \mathrm{g}, 25 \mu \mathrm{g}$ e $50 \mu \mathrm{g}$ foram extremamente tóxicas, ao final do experimento após 24 horas de tratamento não apresentaram células vivas.

O uso da metodologia relativa à microscopia eletrônica revela alterações profundas no citoplasma e núcleo celular de células tratadas com a subfração acetato de etila III, com o comprometimento das estruturas celulares relativas às organelas e estrutura nuclear. As células B16F10 do grupo controle e controle com $0,1 \%$ de tween apresentaram a carioteca e cromatina bem preservadas, presença de pequenos corpúsculos residuais, porém insignificantes.

Após 12 horas do início do tratamento, muitas células mortas podiam ser observadas, 24 horas após muitos debris celulares e células mortas. As células 
submetidas ao tratamento de $30 \mu \mathrm{g} / \mathrm{ml}$ apresentaram características semelhantes ao tratamento de $5 \mu \mathrm{g}$, porém já no início verificava-se uma maior citotoxicidade nas células. Todo esse processo de morte celular pode estar ocorrendo através de apoptose. Conforme a literatura, vários autores identificaram o efeito das lactonas sesquiterpênicas em várias linhagens de células tumorais interferindo na progressão do ciclo celular e induzindo a morte celular por apoptose. (SONG et al., 2005; CHEN et.al. 2006; TABOPTA et.al.2007; CHANG-LONG et al., 2008; ANDERSON et.al.2008; ROZENBLAT et.al. 2008).

A morte celular pode estar ocorrendo por vários motivos. Agentes químicos e drogas provocam lesões que podem ser diretamente ou pela alteração da homeostasia eletrolítica. Neste grupo encontram-se as substâncias citotóxicas, como por exemplo, as drogas antitumorais (ROBBINS; COTRAN, 2005).

A apoptose tem um papel importante no controle do número de células no desenvolvimento de um ambiente fisiológico. Recentes estudos mostram que muitas drogas anticancer ou agentes quimiopreventivos atuam diretamente prevenindo a promoção e progressão do tumor (CHEM et al., 2007).

Estudos mostram uma ativação de caspases envolvidas na apoptose por lactonas sesquiterpênicas (CHEM et al., 2007).

Ao término dos estudos in vitro, após verificar a ação citotóxica da subfração acetato de etila III de Vernonia scorpioides, iniciou-se os testes in vivo para verificar a ação direta da subfração em modelo melanoma in vivo, já que não foram encontradas referências relacionadas a estudo em modelos in vivo com tratamento de Vernonia scorpioides em melanoma.

Nos testes in vivo o tratamento foi realizado intratumoral, com ação direta sobre o tumor devido a estudos anteriores mostrarem a ineficácia da subfração DCM de Vernonia scorpioides em tratamento do modelo de Sarcoma 180 ascítico por via endovenosa. $\mathrm{Na}$ via sistêmica a subfração ficou com sua atividade citotóxica inativada (KREUGER et al., 2009).

Todos os animais dos grupos controle dos experimentos apresentaram as mesmas características: as lesões cutâneas mostraram neoplasia de crescimento rápido, constituído por células pouco coesas, com alta atividade mitótica levando a necrose e ulceração epidérmica característicos de neoplasia de alto grau com alta taxa de mortalidade. 
O baço dos camundongos do grupo controle apresentou aumento volumétrico proporcional à extensão da neoplasia cutânea. Exibiram polpa branca pouco conspícua com acentuada expansão da polpa vermelha por conta de proliferação e infiltração de células linfóides dos sinusóides esplênicos, na ausência de células neoplásicas. Este padrão de alteração caracteriza um tipo de hiperplasia linfóide reacional não folicular análoga à hiperplasia linfóide difusa encontrada nos linfonodos, encontrado em processos infecciosos agudos, rejeição a transplante ou de origem desconhecida (STERNBERG et al., 1999). No presente estudo, os camundongos foram submetidos à injúria neoplásica podendo ser responsável por este tipo de alteração que caracteriza reação imunológica sistêmica, mesmo sem a presença de células neoplásicas no órgão descrito. Não foi encontrado na literatura este tipo de alteração secundária a melanoma.

Após o tratamento com a subfração durante sete dias, verificou-se que nos locais de inoculação, a neoplasia exibiu extensas áreas de necrose de padrão geográfico. Nos camundongos com menor crescimento tumoral, houve maior resposta ao tratamento, inclusive na ausência total de células viáveis em cortes histológicos, sendo substituído por material eosinofílico amorfo rico em melanina. É importante ressaltar que a subfração foi testada em uma neoplasia de alto grau, apresentando elevado crescimento tumoral, onde as células que não entraram em contato direto com a fração em estudo continuaram viáveis com crescimento e atividade mitótica. Assim os camundongos examinados mantiveram extensas neoplasias. Em alguns casos, identificou-se exsudato neutrofílico com formação de micro abscessos podendo ser secundário ao próprio padrão de necrose tumoral ou a inoculação da subfração.

O fígado foi extensamente amostrado em todos os animais tratados com a subfração para a pesquisa de hepatotoxicidade. Todos os cortes mostraram arquitetura histológica preservada, ausência de sinais de hepatite ou de alterações citológicas nos hepatócitos, como esteatose. Concluímos que apesar de tratar-se de substancia citotóxica (PICMAN, 1986), os animais estudados não apresentaram hepatoxicidade com administração tópica da droga.

O rim demonstrou arquitetura preservada, ausência de processo inflamatório, ausência de destacamento do epitélio tubular ou de sinais de glomerulopatias demonstrando não ter ocorrido nefrotoxicidade pela administração tópica da droga. 
Nos camundongos com tratamento a cada dois dias (inicio 48 horas após inoculação do tumor), observou-se que com a aplicação da subfração anteriormente ao surgimento das lesões macroscópicas houve menor crescimento da neoplasia. Todos os camundongos tinham lesões tumorais cutâneas, porém de tamanho menor quando comparadas ao grupo que recebeu tratamento de 7 dias após lesões macroscópicas aparentes (em torno de 10 dias).

Os camundongos com tratamento precoce tiveram alterações lesionais semelhantes às encontradas com o tratamento em dias alternados. Nos dois grupos, a neoplasia não havia alcançado grandes extensões volumétricas quando foi inoculada a subfração acetato de etila III, e no momento em que os animais foram sacrificados, as tumorações eram menores que as do grupo controle, mostrando assim que houve maior efeito do tratamento quando o volume tumoral é menor. Nos casos onde há extensa neoplasia, o efeito da subfração foi extensa necrose com pequeno impacto no volume tumoral total.

Ao final dos tratamentos verifica-se uma redução do volume tumoral significativo quando comparados ao grupo controle. Conforme histopatológico uma extensa área de necrose é vista e a mensuração do volume tumoral comprova a redução tumoral dos animais tratados, porém o tratamento mais eficaz contra melanoma murino em camundongos C57BI6 foi o tratamento onde os animais começaram a receber as doses da subfração acetato de etila III de Vernonia scorpioides após 48 horas da inoculação.

A ação citotóxica direta da subfração acetato de etila III, pode ser em parte, devido à presença de lactonas sesquiterpênicas contida nesta subfração, aos quais apresentam atividade antitumoral já descrita na literatura (BUSKUHL, 2007; KREUGER et al., 2009). Muitos estudos promissores com lactonas sesquiterpênicas têm demonstrado a sua ação citotóxica direta sobre células tumorais de diversas linhagens (SONG et al., 2005; CHEN et al., 2006; TABOPTA et al., 2007; CHANGLONG et al., 2008; ANDERSON et al., 2008; ROSENBLAT et al., 2008).

Ao término desse estudo verificou-se a excelente atividade antitumoral da subfração acetato de etila III, como já era o esperado devido aos resultados obtidos anteriormente. A subfração acetato de etila III manteve sua ação citotóxica direta sobre as células de melanoma B16F10 como visto nos ensaios in vitro na concentração acima de $5 \mu \mathrm{g} / \mathrm{ml}$. No modelo in vivo não ocorreu uma remissão total do tumor devido à grande dificuldade de difusão da droga pela massa tumoral. Em 
nosso estudo verificou-se uma morte celular por necrose na área tumoral onde a subfração conseguiu agir. Quando a droga foi administrada precocemente, verificouse menor crescimento do tumor, sem nódulos satélites. Veículos para a administração da droga devem ser estudados mais tarde com o objetivo de melhorar a penetração da subfração no tecido neoplásico.

Rosenblat em seu estudo sugeriu que a ação citotóxica de lactonas sesquiterpênicas, composto presente na Vernonia scorpioides, pode estar diretamente ligada a alquilação do DNA celular, porém o mecanismo exato que leva as lactonas sesquiterpênicas terem atividade antitumoral in vitro ou in vivo não está ainda bem elucidada (ROSENBLAT et al.,2009).

Muitos estudos ainda devem ser realizados com as subfrações da Vernonia scorpioides. Algumas lactonas sesquiterpênicas já foram isoladas e devem ser estudadas posteriormente, já que sua ação antitumoral tem se mostrado bastante promissora. Pode-se até mesmo servir como um excelente adjuvante no tratamento de neoplasias que dificilmente respondem a quimioterápicos ou neoplasias que apresentam resistência à quimioterapia. Como já foi citado anteriormente, lactonas sesquiterpênicas podem vir a ser uma droga muito promissora no auxilio a esses tratamentos, devido a sua ação indutora de morte celular por apoptose. 


\section{CONCLUSÕES FINAIS}

$\checkmark$ A subfração acetato de etila III de Vernonia scorpioides apresentou citotoxicidade frente às células de melanoma murino B16F10 em concentrações acima de $1 \mu \mathrm{g} / \mathrm{ml}$ em tratamento in vitro.

$\checkmark$ Ocorre morte celular já na primeira hora de tratamento nas concentrações acima de $5 \mu \mathrm{g} / \mathrm{ml}$ em tratamento in vitro.

$\checkmark$ As células de melanoma murino B16F10 quando submetidas a concentrações acima de $5 \mu \mathrm{g} / \mathrm{ml}$ da subfração acetato de etila III de Vernonia scorpioides apresentaram alterações celulares profundas nas primeiras horas, inviabilizando as células.

$\checkmark \mathrm{O}$ tratamento in vivo com a subfração acetato de etila III de Vernonia scorpioides apresentou atividade com ação direta sobre o tumor causando principalmente necrose, na concentração de $5 \mathrm{mg} / \mathrm{kg}$ nos animais tratados.

$\checkmark$ Quando o tumor é tratado com a subfração acetato de etila III de Vernonia scorpioides após 10 dias da inoculação das células tumorais ocorre redução do volume tumoral, porém o desempenho do tratamento é menor.

$\checkmark$ Quando o tratamento é precoce, a resposta do tumor ao tratamento é mais eficaz, podendo mesmo impedir o crescimento da massa tumoral.

$\checkmark$ A subfração acetato de etila III de Vernonia scorpioides apesar de ser citotóxica com ação direta sobre as células tumorais não demonstrou nefrotoxicidade e hepatotoxicidade nos camundongos tratados. 


\section{REFERÊNCIAS}

AJITH, T. A.; JANARDHANAN, K. K. Cytotoxic and antitumor activities af a polypore macrofungus Phellinus rimosus (Brek) Pilat. Jornal of Ethnofharmacology, v. 84, p. 157-162, 2002.

ALBERTON, B. E. Análise fitoquímica e avaliação da toxicidade de Vernonia scorpioides (Lam.) Pers. Itajaí: Universidade do Vale do Itajaí, 2002. Monografia

ALMEIDA, S.; PALHANO, G. C. Vernonia scorpioides (Lam.) Pers.: Avaliação da atividade e efeito cicatrizante em feridas na pele de cobaias. Itajaí: Universidade do Vale do Itajaí, 2001. Monografia

ANDERSON, W. A. D.; JOHN M. KISSANE, M. D. Pathology, 7. ed .Rio de Janeiro RJ: Guanabara Koogan S.A.; 1982.

ANDERSON, K. N.; BEJCEK, B. E.; Parthenolide induces apoptosis in glioblastomas without affecting NF-ḰB. Journal of Pharmacological Sciences, n. 106, p. 318-320, 2008.

AWE, S. O.; OLAJIDE, O.; MAKINDE, J. M. Cathartic effect of the leaf extract of Vernonia amygdalina. Phytotherapy Research, v.12, p. 57-58,1998.

BARBOSA-FILHO, J. M.; ALENCAR, A. A.; NUNES, X. P.; TOMAZ, A. C. A.; SENAFILHO, J. G.; ATHAYDE-FILHO,P. F.; SILVA, M. S.; SOUZA, M. F. V.; CUNHA, E. V. L. Sources of alpha-, beta-, gama-, delta- and epsilon- carotenes: a twentieth century review. Revista Brasileira de Farmacognosia, v. 18, p. 135-154, 2008.

BIONDE, L. R. Influência do hipotireoidismo na progressão do melanoma experimental. 2006. 55 f. Dissertação (Mestrado em ciencias) - Faculdade de Medicina Veterinária e Zootecnia, Universidade de São Paulo, São Paulo, 2006.

BLIND, L. Z.; MOYA, R. F. P. Estudo da atividade antineoplásica das subfrações do extrato bruto de Vernonia scorpioides até o isolamento de uma substância pura. Itajaí:Universidade do Vale do Itajaí, 2005. Monografia. 
BOGONI, M. T. M.; DELLAGNELO, P. Estudo da atividade da subfração da planta Vernonia scorpioides em modelos experimentais de inflamação em camundongos. Itajaí: Centro de Educação Superior de Ciencias da Saúde, Universidade do Vale do Itajaí, 2005. Monografia.

BOHLMANN, F.; MAHANTA, P. K.; JAKUPOVIC, J.; RASTOGI, R. C.; NATU, A. New sesquiterpene lactones from Inula species. Phytochemistry, v. 17, p. 1165-1172, 1978.

BORTNER, C. D.; CIDLOWSKI, J. A. Cellular machanisms for the repression of apoptosis. Annual review of pharmacology and toxicology, v. 42, p. 259-281, 2002.

BRASILEIRO FILHO, G. Bogliolo - patologia geral. Rio de Janeiro: Guanabara Koogan, 2000.

BRISKIN, D. P. Medicinal plants and phytomedicines. Linking plant biochemistry and physiology to human health. Planta Physiology, v. 124, p. 507-1115, 2000.

BRUNETON, J. Elementos de fitoquimica y de farmacognosia. Zaragoza: Acribia, 1991.

BUSKUHL, H. Avaliação in vitro do mecanismo de ação citotóxica de Lactonas Sesquiterpenicas e outras substancias isoladas de Vernonia scorpioides (LAM) PERS. 2007. 119 p. Dissertação (Mestrado em Ciências Farmacêuticas) Universidade do Vale do Itajaí, Itajaí, 2007.

CABRERA, A. L.; KLEIN, R. M. Flora ilustrada Catarinense: I parte as plantas compostas, Tribo: Vernonia. Itajaí: Raulino Reitz, 1980.

CAMPOS, M. P. Avaliação da atividade antifúngica e antibacteriana de extratos e frações de Vernonia scorpioides (Lam.) Pers. Itajaí: Universidade do Vale do Itajaí, 2001. Monografia

CARVALHO, M. G.; COSTA, P. M.; ABREU, H. S. Flavones from Vernonia diffusa. Journal Brazilian Chemistry Societ, v. 10, p. 163-166, 1999. 
CHANG LONG, L.; HEZ HEN, W.; YOUNG PING, H.; YAN FANG, Y.; YAN WEN, L.; JIAN WEN, L. 6-0-Angeloylenolin induces apoptosis through a mitochondrial/caspase and NF-ḰB pathway in human leukemia HL60 cells. Biomedicine \&

Pharmacotherapy. n.62, p. 401-409. 2008.

CHANG, J. Medicinal herbs: drugs or dietary supplements. Biochemical Pharmacology. V. 59, p. 211-219. 2000.

CHEN, C-N.; HUANG, H-H.; WU, C-L.; LIN, C. P. C.; HSU, J. T. A.; HSIEH, H-P.; CHUANG, S-E.; LAI,G-M. Isocostunolide, a sesquiterpene lactone, induces mitochondrial membrane depolarization and caspase-dependent apoptosis in human melanoma cells. Cancer Letters, v. 246, p. 237-252, 2007.

CHEN, X.; ZHAN, Z. J.; ZHANG, X. W.; DING, J.; YUE, J. M. Sesquiterpene lactones with potent cytotoxic activities from Vernonia chinensis. Planta Médica, v. 71, n. 10, p. 949-954, 2005.

CORREA, M. P. Dicionário das plantas úteis do Brasil e das exóticas cultivadas. Rio de Janeiro: Imprensa Nacional, 1978.

DALAZEN, P.; MOLON, A.; BIAVATTI, M. W.; KREUGER, M. R. O. Effects of the topical application of the extract on Vernonia scorpioides on excisional wounds in mice. Brazilian Journal of Pharmacognosy, v. 15, p. 82-87, 2005.

FILDER, I. J. Selection of successive tumour lines for metastasis. Nature new Biology, v. 242, n. 4, p. 148-149, 1973.

FRANK, S. J.; MEYERS, M. Interferons as adjuvant therapy for high risk melanoma. Melanoma Letters, v. 13, p. 1-4, 1995.

FREIRE, M. F. I.; ABREU, H. S.; CRUZ, L. C. H.; FREIRE, R. B. Inhibition of fungal growth by extracts of Vernonia scorpioides (LAM.) Pers. Revista de Microbiologia, v. 27, n. 1, p. 1-6, 1996.

GALLIN, J. L.; SNYDERMAN, R. Inflammation, 3: ed. New York: Lippincott Williams \& Wilkins, 1999. 
GUPTA, M.; MAZUMDER, U. K.; MANIKANDAN, L.; HALDAR, P. K.;

BHATTACHARYA, S.; KANDAR, C. C. Antibacterial activity of Vernonia cinerea.

Fitoterapia, v. 74, p. 148-150, 2003.

HARBORME, J.; BAXTER, H. Phytochemical dictionary. London: Taylor \& Francis, 1993.

HELMBACH, H.; ROSSMANN, E.; KERN, M. A.; SCHDENDORF, D. Drug-Resistance in Human Melanoma. International Journal Cancer, v. 93. p. 617-622, 2001.

HENTY, P. H.; LONGO, D. L.; BRAUNWALD, E.; FAUCI, A. S.; KAPSER, D. L.; LONGO, D. L.; JAMESON, J. L. Harrison's - principles of internal medicine. 15. ed. Rio de Janeiro: McGraw Hill Companies, 2001.

HILMI, F.; GERTSCH, J.; BREMNER, P.; VALOVIC, S.; HEINRICH, M.; STICHER, O.; HEILMANN, J. Cytotoxic versus Anti-inflammatory effects in Hela, Jurkat T and Human peripheral blood cells caused by guaianolide-type sesquiterpenes lactones. Bioorganic \& Medicinal Chemistry, v. 11, p. 3659-3663, 2003.

HUANG, Y.; DING, Z. H.; LIU, J. K. A new highly oxygenated flavone from Vernonia saligna. Z. Naturforsch, v. 58, p. 347-350, 2003.

HWU, W. J.; KROWN, S. E.; MENELL, J. H.; PANAGEAS, K. S.; MERREL, J.; LAMB, L. A. Phase II study of temozolomide plus thalidomide for treatment of metastatic melanoma. Journal Clinical Oncologic, v. 21, p. 3351-3356, 2003.

INCA. Câncer de pele: melanoma. Estimativa 2008. Disponível em http://www.inca.gov.br/estimativa/2008/. Acessado em: 19 fev 2009.

INDAP, M. A.; AMBAYE, R. Y. Efficacy of 5-fluorouracil in combination with methoxyphenyl maleamicacid in murine tumors. Journal of Postgraduated Medicine, v. 37, p. 211-215, 1991.

IZEVBIGIE, E. B.; BRYANT, J. L.; WALKER, A. A novel natural inhibitor of extracellular signal-regulates kinases and human breast cancer cell growt. Experimental Biology and Medicine, v. 229, p.163-169, 2004.

KHALIL, A.T.; SHEN, J. H. G.; CHENG, S. Y. et al. Two new sesquiterpene lactones from Ixeris chinesis, Chemical \& Pharmaceutical Bulletin, v. 53, p. 15-17, 2005. 
KIM, J. H.; LIU, L.; LEE, S. O.; KIM, Y. T.; YOU, K. R.; KIM, D. G.; Susceptibility of cholangiocarcinoma cells to parthenolide-induced apoptosis. Cancer research, v. 65, n. 14, p. 6312-6320, 2005.

KIRKWOOD, J. M.; EMSTOFF, M. Role of interferons in the therapy of melanoma. Journal Investigation Dermatology, v. 95, p. 180s-184s, 1990.

KONISH, T.; SHIMADA, Y.; NAGAO, T.; OKABE, H.; KONOSHIMA, T. Antiproliferative sesquiterpene lactones from the roots os Inula helenium. Biological \& Pharmaceutical Bulletin, v. 25, p. 1370-1372, 2002.

KREUGER, M. R. O., BIAVATTI, M. W., PACHECO, E. S., JUNIOR, R. R. A., BLIND, Z. B. Ação citotóxica da sub-fração 2125 de Vernonia scorpioides contra células do Sarcoma 180 em camundongos. Revista Brasileira de Farmacognosia, v.19, n.2A, p.353-357, 2009.

KUMARI, G. N. K.; MASILAMANI, S.; GANESH, M. R.; ARAVIND, S.; SRIDHAR, S. R. Zalazanin D: a fungistatic sesquiterpene from Vernonia asborea. Fitoterapia, v. 74, p. 479-482, 2003.

LANS, C.; HARPER, C.; GEORGES, K.; BRIDGEWATER, E. Medicinal and ethnoveterinary remedies of hunters in Trinidad. BMC Complementary and Alternative Medicine, v. 1, p. 10, 2001.

LEITE, S. N.; PALHANO, G,; ALMEIDA, S.; BIAVATTI, M. W. Wound healing activity and systemic effects of Vernonia scorpioides extract in guinea pig. Fitoterapia, v. 73, p. 496-500, 2002.

LOPES, J.L. Memorial Instituto Oswaldo Cruz, v.86, n. 2, p. 227-230, 1991. Supplement.

LORENZI, H. Plantas daninhas do Brasil. 3. ed. Nova Odessa: Instituto Plantarum, 2000. $608 \mathrm{p}$.

MANS, D. R. A.; ROCHA, A. B.; SCHWARTSMANN, G. Anti-Cancer drug discovery and development in Brazil: targeted plant collection as a rational strategy to acquire candide anti-cancer compounds. The Oncologist , v. 5, p.185-198, 2000.

MELNIKOVA, V. O.; MENASHE, B. Inflammation and melanoma metastasis.

Pigment Cell Melanoma Research, v. 22, p. 257-267, 2009. 
MILLER, A. J.; MIHM, M. C. Melanoma. New England Journal of Medicine, v. 355, n. 1 , p. 51-65, 2006.

MONTEIRO, M. H. D.; GOMES-CARNEIRO, M. R.; FELZENSZWALB, I.;

CHAHOUD, I.; PAUMGARTTEN, F. J. R. Toxicological evalution of a tea from leaves of Vernonia condensate. Journal of Ethnopharmacology, v. 74, p. 149-157, 2001.

MUHAMMAD, I.; TAKAMATSU, S.; MOSSA, J. S.; EI-FERALY, F. S.; WALKER, L. A.; CLARK, A. M. Citotoxic sesquiterpene lactones from Centaurothammus maximus and Vicoa pentanema. Phytotherapy Research, v. 17 p. 168-173, 2003.

MULLER, S. et al. Sesquiterpene lactones from Montanoa hibiscifolia that inhibit the transcription factor NF-kappa B. Journal Natural Product, v. 67, p. 622-630, 2004.

NEVIN, K. G.; VIJAYAMMAL, P. L. Effect of Aerva lanata on solid tumor induced by DLA cells in mice. Fitoterapia, v. 74, n. 6, p. 577-581, 2003.

NUNES, D. S. Chemical approaches to the study of ethnomedicinal. In: BALICK, M.; ELISABETSKY, E.; LAIRD, S. (Ed.). Medicinal resources of the tropical forest: biodiversity and its importance to humen health. New York: Columbia Univ., 1996.

OHGUCHI, K.; ITO, M.; YOKOYAMA, K.; IINUMA, M.; ITOH, T.; NOZAWA, Y.; AKAO, Y. Effects of Sesquiterpene Lactones on Melanogenesis in Mouse B16 Melanoma Cells. Biology Pharmacology Bull. v. 32, n.2, p.308-310, 2009.

PACHECO, E. S.; JUNIOR, R. R. D. Análise da atividade antitumoral da sufração 2125 da planta vernonia scorpioides no sarcoma 180 em camundongos. Itajaí: Centro de Educação Superior de Ciencias da Saúde. Universidade do Vale do Itajaí, 2005. Monografia

PAGNO, T. Estudo da atividade antineoplásica da fração dicloromentano (DCM) da planta Vernonia scorpioides (Lam.) Pers. em modelo animal. Itajaí: Centro de Educação Superior de Ciências da Saúde. Universidade do Vale do Itajaí, 2003. Monografia

PAGNO, T.; BLIND, L. Z.; BIAVATTI, M. W.; KREUGER, M. R. O. Cytotoxic activity of the dichloromethane fraction from Vernonia scorpioides (Lam.) Pers. (Asteraceae) against Ehrlich's tumor cells in mice. Brazillian Journal of Medical and Biological Research. v. 39, n. 11, p. 1483-1491, 2006. 
PEREIRA, R. S.; UMITA, T. C.; FURLAN, M. R.; JORGE, A.; UENO, M. Atividade antibacteriana de óleos essenciais em cepas isoladas de infecção urinária. Revista Saúde Pública, São Paulo, v. 38, n. 2, 2004.

PICMAN, A. K. Biological activities of sesquiterpene lactones. Biochemical Systematics and Ecology, v. 12, n. 1, p. 225-281, 1986.

PRIGNANO, F.; CORONNELLO, M.; PIMPINELLI, N.; CAPPUGI, P.; MINI, E.; GIANNOTTI, B. Immunophenotypical markers, ultrastructure and chemosensitivity profile of metastatic melanoma cells. Cancer Letters, v. 186, p. 183-192, 2002.

QUINTERO, A.; PELCASTRE, A.; SOLANO, J. D.; GUZMAN, A.; DIAZ, E. Antitumoral activity of new pyrimidine derivaties of sesquiterpenes lactones. Journal Pharmacology Pharmaceutic Science, v. 2, p. 108-112, 1999.

QUEIROLO, P.; ACQUATI, M.; KIRWOOD, J. M.; EGGRMONT, A. M. M.; ROCCA, A.; TESTORI, A. Update: current management issues in malignant melanoma.

Melanoma Research., v. 15, p. 319-324, 2005.

REITZ, R. Flora ilustrada catarinense. Itajaí: Herbário Barbosa Rodrigues, 1980.

ROBBERS, J. E.; SPEEDIE, M. K.; WARRS, E. T. Farmacognosia e biotecnologia. Colômbia: Premier, 1997.

ROBBINS, S. T.; COTRAN, R. S. Patologia. Bases patológicas das doenças. 7. ed. Rio de Janeiro: Elsevier, 2005.

RODRIGUEZ, E.; TOWERS, G.; MITCHELL, J. Biological activities of sesquiterpene lactones. Phytochemistry, v. 15, p. 1573-1580, 1976.

ROZENBLAT, S.; GROSSMAN, S.; BERGMAN, M.; GOTTLIEB, H.; COHEN. Y.; DUVRAT. $S$. Induction of $\mathrm{G}_{2} / \mathrm{M}$ arrest and apoptosis by sesquiterpene lactones in human melanoma cell lines. Biochemical Pharmacology, v. 75, p. 369-382. 2008.

SASSI, F. C. Produtos fitoterápicos. Fármacos e Medicamentos, Rio de Janeiro, n. 5, p. 45-47, jul/ago. 2000.

SCHICHER, N.; PAULITSCHKE, V.; SWOBODA, A.; KUNSTFELD, R.; LOEWE, R.; PILARSKI, P.; PEHAMBERGER, H.; HOELLER, C. Erlotinib and Bevacizumab have synergistic activity against Melanoma. Clinical Cancer Research, v. 15, n. 10, p. 3495-3502, 2009. 
SONG. Y. J.; LEE. D. Y.; KIM. S.; LEE. K. R.; LEE. H. W.; HAN. J.; KANG. D.; LEE. H. Y.; KIM. Y. K. Apoptotic potential of sesquiterpene lactone ergolide through the inhibition of NF-ḰB signaling pathway. Pharmacy and Pharmacology, n. 5, p. 15911597, 2005.

SPECTOR, D. L.; GOLDMAN, R. D.; LEINWAND, L. A. Apoptosis assays. In: Cells: a laboratory manual. Cold Spring Harbor, NY: Cold Spring Harbor Laboratory Press. 1998 .v. 1, p. 156.

STERNBERG, S. P.; ANTONIOLI, D. A.; CARTER, D.; MILLS, S. E.; OBERMAN, H. A. Diagnostic surgical pathology. 3. ed. 1. Lippincott. Williams \& Wilkins.

SWEENEY, C. J., MEHROTRA, S., SADARIA, M. R., KUMAR, S., SHORTLE, N. H., ROMAN, Y., SHERIDAN, C., CAMPBELL, R. A., MURRY, D. J., BADVE, S., NAKSHATRI, $\mathrm{H}$. The Sesquiterprne Lactone parthenolide in combination with docetaxel reduces metastasis and improves survival in xenograft model of breast cancer. Molecular Cancer Therapy, v. 4, p. 1004-1012, 2005.

TABOPTA, T. K.; LIU, J.; NGADJUI, B. T.; LUU, B. Citotoxic triterpene and sesquiterpene lactones from Elephantopus mollis and induction of apoptosis in neuroblastoma cells. Planta Medical, p. 376-380. 2007

TALALAY, P.; TALALAY, P. The importance of using scientific principles in the development of medicinal agents from plants. Academic Medicine. V. 76, n. 3, p. 238-247. 2001.

UMEMURA, K.; ITOH, T.; HAMADA, N.; FUJITA, Y.; AKAO, Y.; NOZAWA, Y.; MATSUURA, N.; LINUMA, M.; ITO, M. Biochemic Biotechnologic Biochemistry, v. 69, p. 2470-2474, 2005.

ZHANG, S.; WON, Y. K.; ONG, C. N.; SHEN, H. N. Anti-cancer potential os sesquiterpene lactones: bioactivity and molecular mechanisms. Current medicinal chemistry. Anti-cancer agents. v. 5, p. 239-249, 2005. 